University of Nebraska - Lincoln

DigitalCommons@University of Nebraska - Lincoln

2019

Nebraska Farm Real Estate Market Highlights 2018-2019

Jim Jansen

University of Nebraska-Lincoln, jjansen4@unl.edu

Jeffrey Stokes

University of Nebraska-Lincoln, jeffrey.stokes@unl.edu

Follow this and additional works at: https://digitalcommons.unl.edu/ageconfarmmgmt

Part of the Agribusiness Commons, Agricultural and Resource Economics Commons, Agricultural Economics Commons, Entrepreneurial and Small Business Operations Commons, Management Information Systems Commons, Other Business Commons, Other Economics Commons, and the Real Estate Commons

Jansen, Jim and Stokes, Jeffrey, "Nebraska Farm Real Estate Market Highlights 2018-2019" (2019). Extension Farm and Ranch Management. 43.

https://digitalcommons.unl.edu/ageconfarmmgmt/43

This News Article is brought to you for free and open access by the Agricultural Economics Department at DigitalCommons@University of Nebraska - Lincoln. It has been accepted for inclusion in Extension Farm and Ranch Management by an authorized administrator of DigitalCommons@University of Nebraska - Lincoln. 

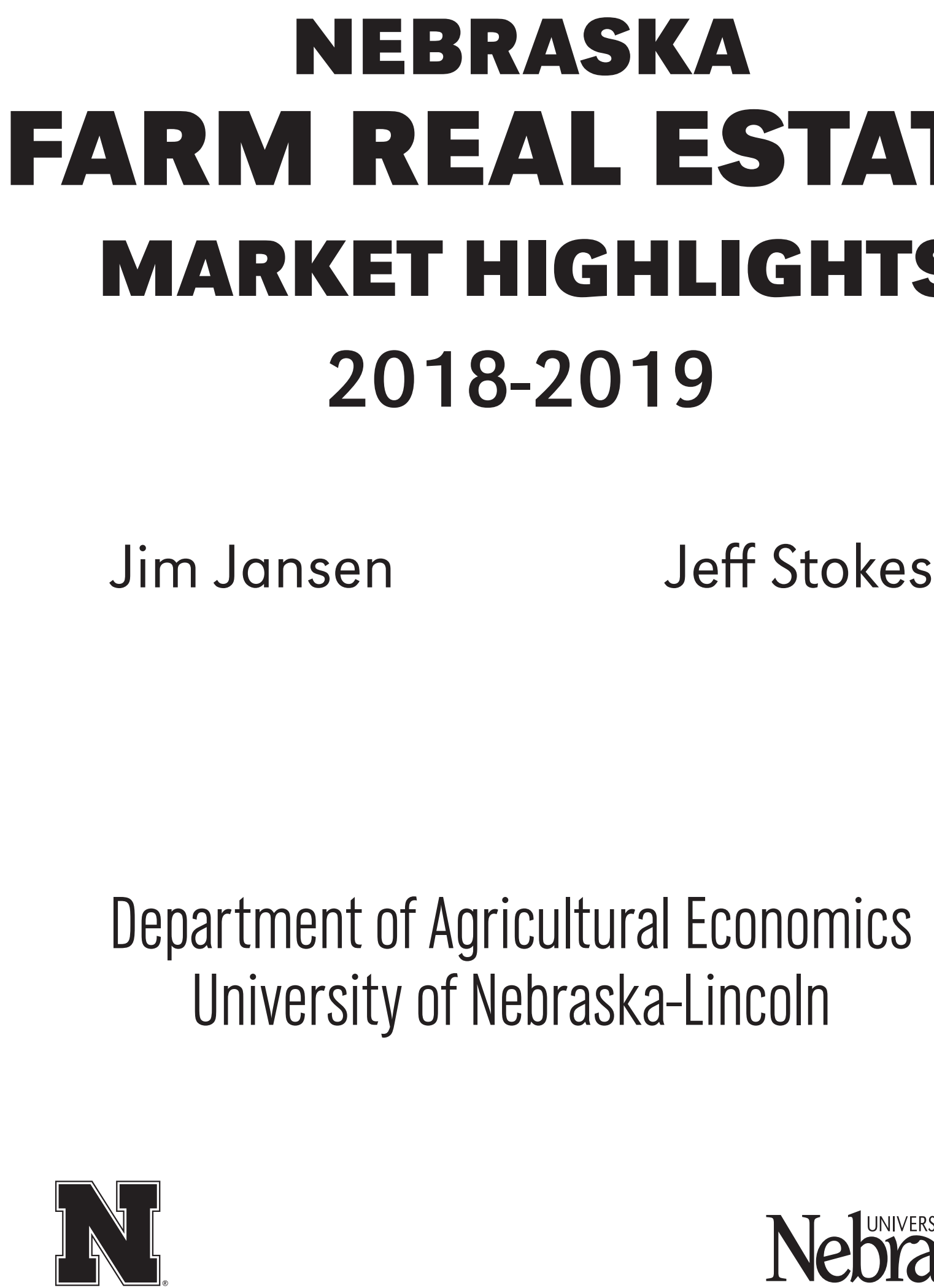


\title{
Nebraska Farm Real Estate Market Highlights \\ 2018-2019
}

\author{
By \\ Jim Jansen* \\ and \\ Jeffery Stokes ${ }^{\star *}$
}
* Agricultural Economist, Northeast District, Eastern Nebraska Research and Extension Center;
Department of Agricultural Economics, University of Nebraska-Lincoln.
Phone: (402) 261-7572; email: jjansen4@unl.edu
** Hanson-Clegg-Allen Endowed Chair, Agricultural Banking and Finance, Department of Agricultural Economics, University of Nebraska-Lincoln.
Phone: (402) 472-1742; email: jeffrey.stokes@unl.edu

Sincere appreciation goes to the panel members for their participation in the UNL 2019 Nebraska Farm Real Estate Market Survey. Without their valuable input, much of the information within this report would not exist.

Special appreciation also goes to Dr. Bruce Johnson who conducted the UNL Nebraska Farm Real Estate Developments Survey from 1978 until his retirement in 2013. His advice and insight have been critical to the success of the survey and report.

Recognition is also extended to Linda Tesch, Maddy Griep, and Sandy Sterkel for their significant contributions throughout the survey, report analysis, and publication process.

NOTE: This report is available at agecon.unl.edu/realestate

If electronic copies are not accessible, hard copies of these highlights can be purchased for $\$ 7.00$ per copy from:

Department of Agricultural Economics

University of Nebraska-Lincoln

Attn: Real Estate Report

207 Filley Hall

Lincoln, NE 68583-0922

It is the policy of the University of Nebraska-Lincoln not to discriminate based upon age, race, ethnicity, color, national origin, gender-identity, sex, pregnancy, disability, sexual orientation, genetic information, veteran's status, marital status, religion or political affiliation. 


\section{Disclaimer}

The Nebraska Farm Real Estate Market Highlights 2018-2019 publication was created for educational purposes to provide insight on recent trends in agricultural land values and rental rates across Nebraska. Agricultural land values and rental rates in the report represent averages for different regions of the state. Actual agricultural land values or rental rates for an individual parcel in Nebraska will vary from reported figures depending on quality attributes and local market forces of the area.

Agricultural land values and rental rates for this publication were obtained by surveying expert panel members engaged in agricultural land and rental markets throughout Nebraska. The panel member's validity relies on their expertise and accuracy and the authors do not make any guarantees as to their qualifications or the reliability of their responses. While survey responses were examined to eliminate data that was obviously erroneous, no further effort was made to independently verify or corroborate the data.

Physical attributes such as location, soil type, topography, or depth to water may affect the value of a given real property causing the value to deviate substantially from what may be considered normal for the area. Also, local market forces such as the competitive nature of an area and local government policies such as restrictions on the use of water all have the ability to greatly impact agricultural land values or rental rates.

In addition, variations exist within reporting Districts that may cause real estate values and rental rates to differ substantially within the region. As an example, the North reporting district spans almost 200 miles from east to west. Precipitation in Nebraska decreases on average an inch every 25 miles a person travels westward resulting in a possible decline of eight inches from the eastern side of this district to the west. An eight-inch difference in precipitation for a semi-arid region will substantially change the value and rental rates for crop and range ground.

Due to the inherent limitations of this survey, some of which are listed above, information in this report should not be used to set a specific rental rate or value a particular parcel of real property for sale or property taxes, security for a loan, and other related legal matters. 



\section{Table of Contents}

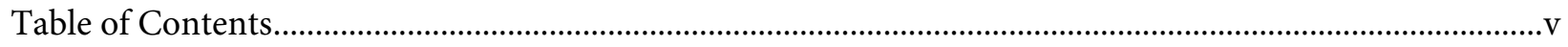

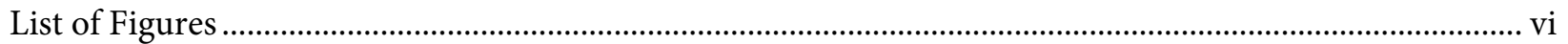

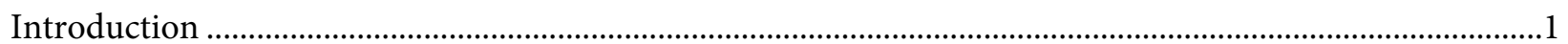

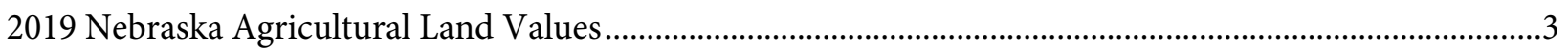

Table 1. Average Reported Value of Nebraska Farmland for Different Land Types by Agricultural Statistics District, February 1, 2019..............................................................................

Table 2. 2019 Values and Recent Trends by Area of the State ....................................................................6

Table 3. 2019 Values and Recent Trends by Land Class in Nebraska ..........................................................6

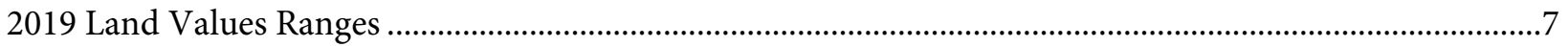

Table 4. Average Reported Value Per Acre of Nebraska Farmland for Different Types and Grades of Land in Nebraska by Agricultural Statistics District, February 1, 2019 .......................7

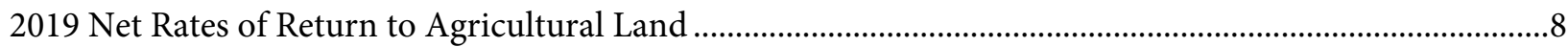

Table 5. Estimated Annual Net Rates of Return by Type of Land and Agricultural Statistics District, Selected Years 2015-2019 ......................................................................................................

Factors Influencing Current Agricultural Land Markets .................................................................................. 10

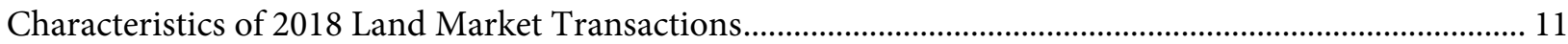

Table 6. Land Characteristics of 2018 Agricultural Real Estate Transactions, by Agricultural Statistics District in Nebraska ......................................................................................................... 11

Table 7. Types of Financing Associated with 2018 Agricultural Real Estate Sales, by Agricultural Statistics District in Nebraska.............................................................................. 12

Table 8. Percent Distribution of Agricultural Real Estate Transactions in 2018 by Buyer Type, by Agricultural Statistics District in Nebraska.................................................................................. 12

Table 9. Percent Distribution of Agricultural Real Estate Transactions in 2018 by Seller Type,

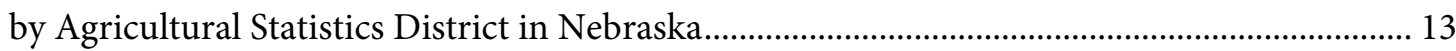

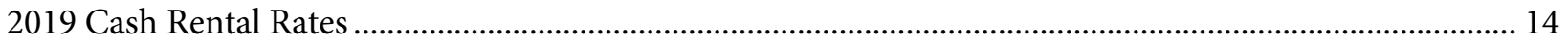

Table 10. Reported Cash Rental Rates for Various Types of Nebraska Farmland and Pasture: 2019 Averages, Percent Change from 2018 and Quality Ranges by Agricultural Statistics District

Table 11. Reported Cash Rental Rates for Pasture on a Monthly Rate Basis for 2019: Averages and Ranges by Agricultural Statistics District.

Special Feature: Cover Crop Utilization Across Nebraska and Implications for

Cropland Lease Arrangements in 2019

Table 12. Cover Crop Practices for Cropland and Operators in 2017, by Agricultural Statistics District in Nebraska. 


\section{Table of Contents (continued)}

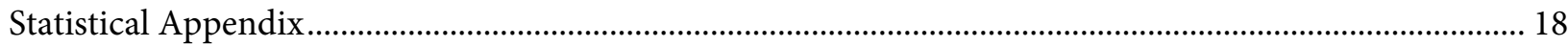

Appendix Table 1. Farm Real Estate Values in Nebraska, USDA Historical Series, 1860-2019a ............ 19

Appendix Table 2. Deflated USDA Farmland Values and Percent Changes for Nebraska, 1930

to 2019

Appendix Table 3. Nominal and Deflated Agricultural Land Values by Selected Types of Land in Nebraska, 1978 to 2019

Appendix Table 4. Average Reported Value of Nebraska Farmland for Different Types of Land by Agricultural Statistics District, 1978-2019.

Appendix Table 5. Historical Per Acre Value Range for Different Types and Quality Grades of Land in Nebraska by Agricultural Statistics District, 2015-2019.

Appendix Table 6. Estimated Annual Net Rates of Return to Nebraska Farmland for Different Types of Land by Agricultural Statistics District, 1990-2019

Appendix Table 7. Historical Average Cash Rental Rates of Nebraska Farmland for Different Types of Land by Agricultural Statistics District, 1981-2019 48

\section{List of Figures}

Figure 1. Nebraska Agricultural Statistics Districts

Figure 2. Average Value of Nebraska Farmland, February 1, 2019 and Percent

Change From Year Earlier.

Figure 3. Historical Nebraska All-Land Average Value per Acre and Marketing Year Average Price of Corn, Selected Years 1979-2019

Figure 4. Historical Estimated Annual Net Rates of Return by Land Type in Nebraska, Selected Years 1991-2019.

Figure 5. Reporters' Rating of Factors Influencing Agricultural Land Values in Their Areas of Nebraska, February 2019. 10

Figure 6. Reasons for Planting Cover Crops on Cropland in Nebraska. 17

Figure 7. Rental Discount in Dollars per Acre on Land Lease When Tenant Plants Cover Crops in Nebraska 17 


\section{Introduction}

The Nebraska Farm Real Estate Market Highlights 2018-2019 report represents the $41^{\text {st }}$ edition to the annual series. These reports provide an important insight on agricultural land market dynamics for stakeholders across Nebraska. In today's market, where market transactions exceeding a million dollars are the norm, objective market information and analysis is more critical than ever. The focus of the report continues to provide unbiased information on agricultural land values and rental rates so industry participants can make educated and informed decisions.

This year, the February 2019 survey of nearly 125 expert-panel members from across the state provided current information and insight regarding the agricultural land market conditions in their areas. The panel members have been selected on the basis of being actively engaged in agricultural land markets as certified agricultural appraisers, professional farm managers, agricultural lenders primarily focused on agricultural land transactions, and other professionals engaged in the Nebraska agricultural land industry due to the inherit nature of their positions. The majority of panelists participating in the survey have reported annually for a considerable number of years which provides valuable historical consistency and context to the agricultural land values and rental rates provided.

Based on their knowledge of market activity, reporters provide point-in-time estimates of current agricultural land values and cash rental rates for a variety of land types and classes. Comparing these current measures against previous years' results provides important trend analysis. The appendix in this report includes: the historical UNL data series for Nebraska agricultural land values dating back to 1978, the agricultural cash rental rate series dating back to 1981, and the USDA historical all-land value series.

In addition to the point-in-time estimates, panel members provide details regarding actual sales transactions which have occurred over the previous 12 months. This year the panel provided information on 505 sales that were considered representative of the recent agricultural land market. This gives insight into the characteristics of recent sales as well as benchmark indicators for studying trends. Changes in the nature of market participants engaged in land transactions from year-to-year may also be ascertained from evaluating this information. 
Figure 1. Nebraska Agricultural Statistics Districts

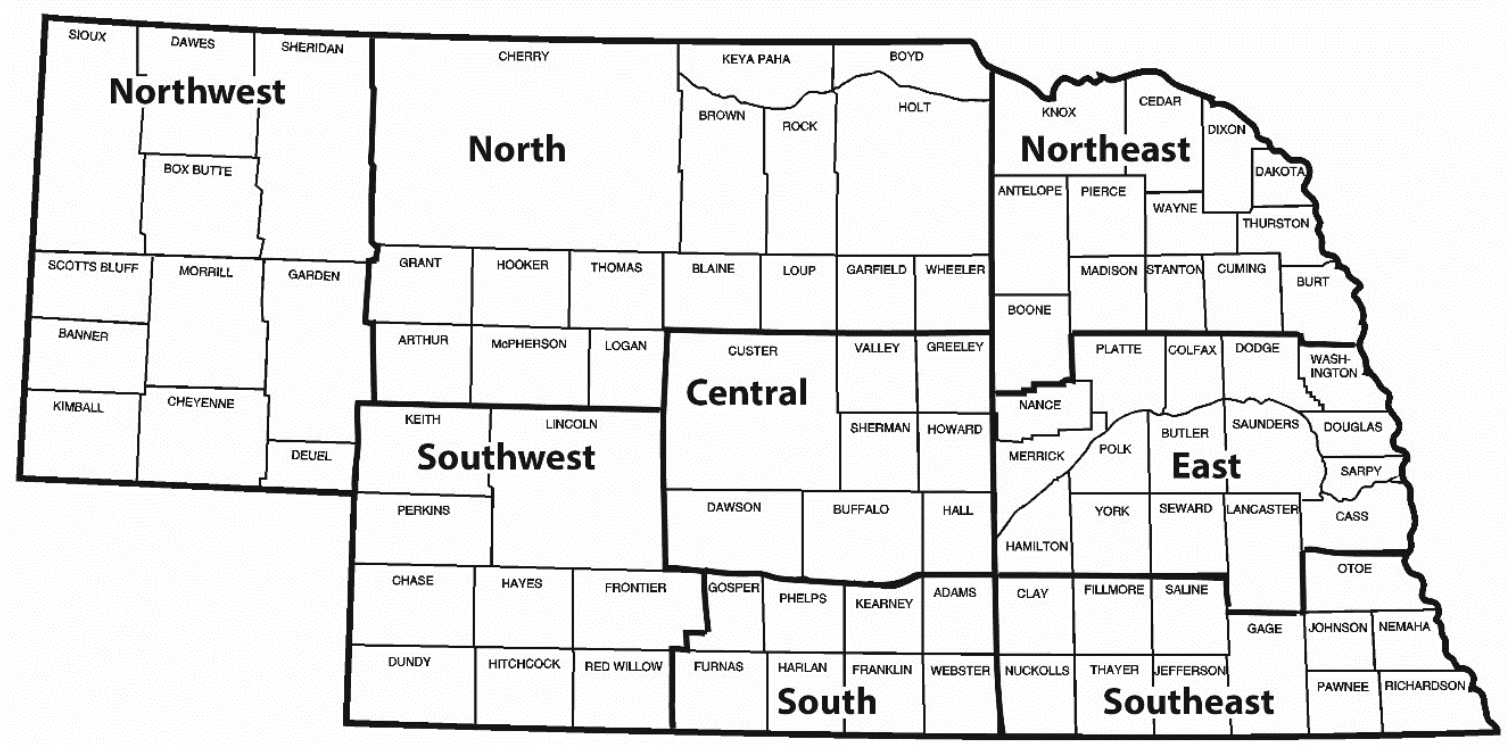

Nebraska has diverse land resource characteristics and agricultural patterns. Most of the market information is provided down to sub-state regions which are the Nebraska Agricultural Statistics Districts (Figure 1). Land within these regions shares similar geographical attributes and production expectations. The districts provide greater geographically-appropriate detail that are not available from other data sources, such as quarterly value estimates from the Kansas City Federal Reserve, the USDA-Economic Research Service Annual Farm Value and Cash Rent series for the state as a whole.

Variability exists within these eight sub-state regions. Therefore, sub-state regions of values and cash rents appropriately may not necessarily reflect the conditions of any local market in that geographic area. Differences in local values and rents can range from small to extreme. The information and analysis to follow in the report is a more realistic measure of general patterns and trends. Should one need information for one specific parcel, the services of a certified agricultural appraiser or a professional farm management firm should be solicited. 


\section{Nebraska Agricultural Land Values}

Marking a half decade of declines, the all-land average value in Nebraska for the year ending February 1, 2019 averaged about 3 percent lower than the prior period. Figure 2 summarizes these figures and trends along with the percent changes over the prior year's all-land average for the eight districts in the state.

Figure 2. Average Value of Nebraska Farmland, February 1, 2019 and Percent Change From Year Earlier

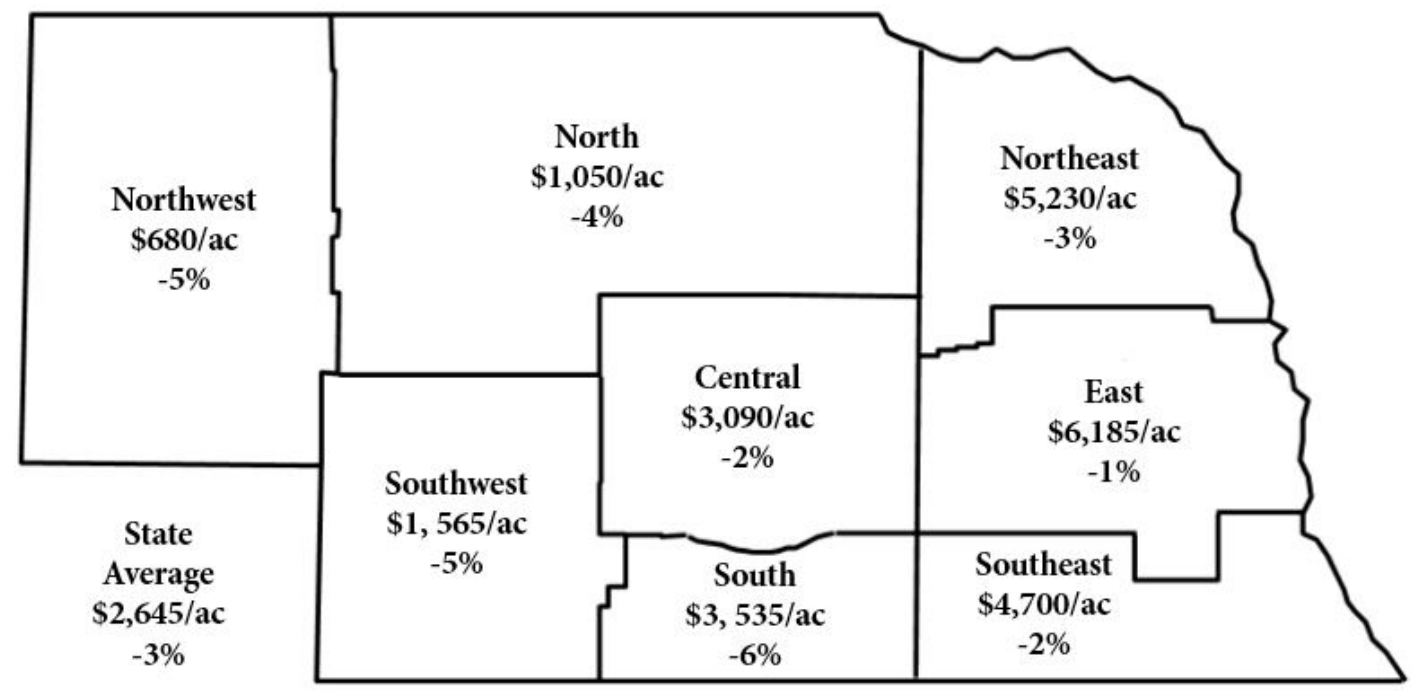

Source: UNL Nebraska Farm Real Estate Market Surveys, 2018 and 2019.

- The state wide all-land average value for the year ending February 1,2019 averaged \$2,645 per acre or about a 3 percent ( $\$ 75$ per acre) decline to the prior year's value of $\$ 2,720$ per acre (Figure 2 ).

- Rates of decline were lower in the eastern third and central region of Nebraska compared to the western two-thirds of the state.

- In the western regions of Nebraska, including the Northwest, North, Southwest, and South Districts these areas averaged from 4 to 6 percent lower for the all-land average. The Northeast, Central, East, South, and Southwest Districts declined slightly from 1 to 3 percent.

- Panel members reported in 2019 current crop prices, property taxes, and farm input costs as the most negative forces leading to the lower market value of land across the state. Additional economic forces placing strong negative pressure on the real estate markets included future property tax policies and the financial health of current owners.

- The outlook on the future growth for the market value of land values remains very bleak as the panel members noted 1031 tax exchanges and purchases for farm expansions as negligibly positive. Interest by non-farmer investors in land purchases along with the amount of land offerings for sale provided were also slightly negative.

- Based on 2019 market values, the estimated total value of agricultural land and buildings in Nebraska fell to approximately $\$ 125.3$ billion. Appendix Table 1 gives a historical perspective on the estimated market value of land and related buildings in the state. Between 2018 and 2019, the market value decline in agricultural land and building totaled about $\$ 3.6$ billion. 
Table 1. Average Reported Value of Nebraska Farmland for Different Land Types by Agricultural Statistics District, February 1, 2019a

\begin{tabular}{|c|c|c|c|c|c|c|c|c|c|}
\hline \multirow{2}{*}{$\begin{array}{c}\text { Type of Land } \\
\text { and Year }\end{array}$} & \multicolumn{9}{|c|}{ Agricultural Statistics District } \\
\hline & Northwest & North & Northeast & Central & East & Southwest & South & Southeast & State \\
\hline \multicolumn{10}{|c|}{ 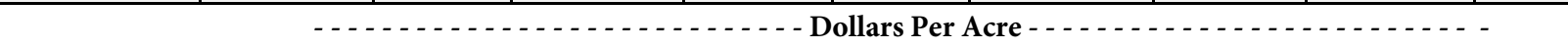 } \\
\hline \multicolumn{10}{|c|}{ Dryland Cropland (No Irrigation Potential) } \\
\hline$\$$ /acre & 645 & 1,495 & 5,300 & 2,755 & 5,765 & 1,445 & 2,880 & 4,130 & 3,040 \\
\hline$\%$ change & -4 & -1 & -4 & 1 & 2 & -9 & -3 & -2 & -2 \\
\hline \multicolumn{10}{|c|}{ Dryland Cropland (Irrigation Potential) } \\
\hline$\$ /$ acre & 680 & 1,915 & 5,640 & 3,055 & 6,145 & 1,585 & 3,450 & 5,265 & 4,010 \\
\hline$\%$ change & -7 & -4 & -3 & -1 & -2 & -3 & -5 & -1 & -3 \\
\hline \multicolumn{10}{|c|}{ Grazing Land (Tillable) } \\
\hline$\$ /$ acre & 500 & 1,040 & 3,125 & 1,750 & 3,075 & 880 & 1,875 & 2,760 & 1,185 \\
\hline$\%$ change & -2 & -3 & -6 & -10 & -8 & -7 & -4 & -3 & -5 \\
\hline \multicolumn{10}{|c|}{ Grazing Land (Nontillable) } \\
\hline$\$ /$ acre & 410 & 625 & 1,995 & 1,405 & 2,255 & 735 & 1,335 & 1,970 & 795 \\
\hline$\%$ change & -6 & -2 & -7 & -9 & -4 & -6 & -9 & -4 & -5 \\
\hline \multicolumn{10}{|l|}{ Hayland } \\
\hline$\$ /$ acre & 710 & 1,140 & 3,020 & 1,885 & 3,040 & 1,255 & 1,990 & 2,645 & 1,615 \\
\hline$\%$ change & -7 & -10 & -4 & -5 & 2 & -8 & -3 & 1 & -6 \\
\hline \multicolumn{10}{|c|}{ Gravity Irrigated Cropland } \\
\hline$\$ /$ acre & 2,245 & 3,570 & 6,510 & 5,860 & 7,585 & 3,700 & 5,365 & 5,900 & 5,690 \\
\hline$\%$ change & -4 & -2 & -3 & 1 & 2 & -5 & -7 & -6 & -2 \\
\hline \multicolumn{10}{|c|}{ Center Pivot Irrigated Cropland ${ }^{b}$} \\
\hline$\$$ /acre & 2,565 & 3,905 & 7,210 & 6,390 & 8,485 & 4,110 & 6,150 & 7,470 & 5,970 \\
\hline$\%$ change & -5 & -3 & -1 & -2 & -2 & -4 & -6 & -3 & -3 \\
\hline \multicolumn{10}{|c|}{ All-Land Average ${ }^{c}$} \\
\hline$\$ /$ acre & 680 & 1,050 & 5,230 & 3,090 & 6,185 & 1,565 & 3,535 & 4,700 & 2,645 \\
\hline$\%$ change & -5 & -4 & -3 & -2 & -1 & -5 & -6 & -2 & -3 \\
\hline
\end{tabular}

Source: ${ }^{a}$ UNL Nebraska Farm Real Estate Market Surveys, 2018 and 2019.

${ }^{\mathrm{b}}$ Value of pivot not included in per acre value.

${ }^{c}$ Weighted averages.

- The February 1, 2019 Nebraska all-land average price of \$2,645 per acre marks a 3 percent decline from the prior year (Table 1). The state-wide Nebraska all-land average peaked half a decade ago at $\$ 3,315$ per acre in 2014 and subsequently declined approximately 20 percent over the last 5 years.

- Dryland cropland and irrigated cropland reported declines ranging from 2 to 3 percent lower than the prior year. Grazing land and hayland lost about twice as much for their market value in percentage terms as compared to dryland cropland. Dryland cropland having no irrigation potential and with irrigation potential reported averages of $\$ 3,040$ and $\$ 4,010$ per acre, respectively.

- Gravity and irrigated cropland noted small drops in the market values ranging in declines between 2 and 3 percent. The state-wide averages for gravity and center pivot irrigated cropland were $\$ 5,690$ and $\$ 5,970$ per acre. Once again, the higher rates in decline ranging from 4 to 7 percent came from the Northwest, Southwest, and South Districts where panel members note restrictions in irrigation appropriations and new developments.

- Land classes serving the livestock industry including grazing land being either tillable or nontillable along with hayland noted the highest rate of decline between 5 and 6 percent. State-wide averages of $\$ 1,185$ and $\$ 795$ per acre for grazing land tillable and nontillable were reported along with hayland at $\$ 1,615$ per acre. 
Figure 3. Historical Nebraska All-Land Average Value per Acre and Marketing Year Average Price of Corn, Selected Years 1979-2019

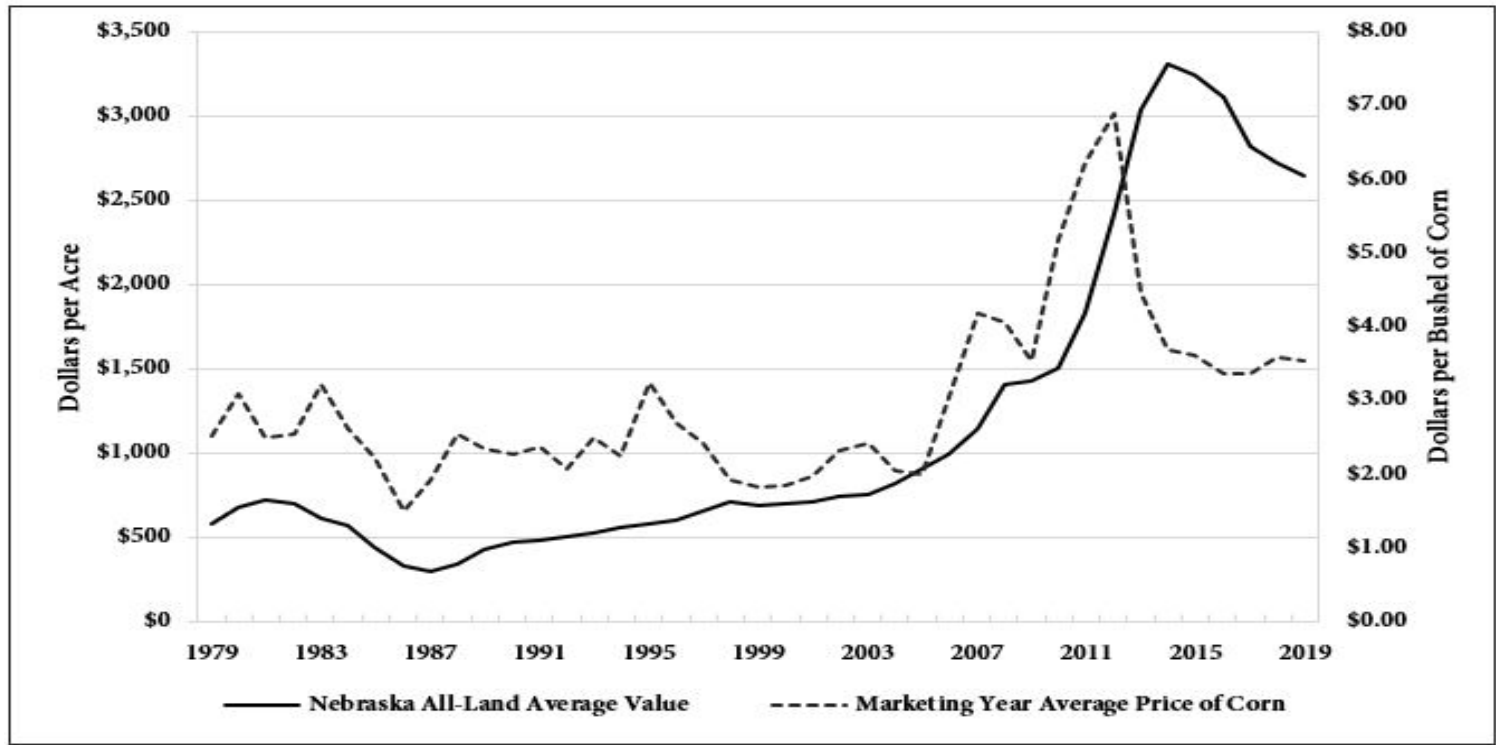

Source: a UNL Nebraska Farm Real Estate Market Surveys, 1979-2019.

b World Agricultural Supply and Demand Estimates (WASDE), Office of the Chief Economist, USDA, 1979-2019.

Preliminary Marketing Year Average price estimates for corn in 2018 and 2019.

- Nebraska farm real estate set the highest nominal (non-inflation adjusted) market value for the all-land average in 2014 at $\$ 3,315$ per acre. Two years prior to the market high, the price of corn peaked at $\$ 6.89$ in 2012 during the record setting drought period (Figure 3).

- The prolonged downturn in commodity prices has panel members and stakeholders concerned about the financial circumstance of many agricultural producers across the state. As a result, since the peak in the all-land market value, the price of land has declined $\$ 670$ per acre.

- Panel members indicated concern on trade with the United States and other nations as this economic force might negatively impact farm real estate values markets across the state. The effects of trade have been felt throughout Nebraska on commodity prices and negative basis-levels. The long-term effect of this force may carry forward into future market values across the state.

- Once again, current and future property tax policies ranked highly negative in Nebraska by panel members on their future effect for land values across the state. Landowners look to property tax discussions in state-level public policy for potential relief in real estate taxes. 
Table 2. 2019 Values and Recent Trends by Area of the State ${ }^{a}$

\begin{tabular}{|c|c|c|c|c|}
\hline $\begin{array}{c}\text { Agricultural Statistics } \\
\text { District }\end{array}$ & $\begin{array}{l}2019 \text { All-Land } \\
\text { Average Value }\end{array}$ & 1-Year Change & 3-Year Change & 5-Year Change \\
\hline & \multicolumn{4}{|c|}{-- Percent Change - } \\
\hline Northwest & 680 & -5 & -17 & -20 \\
\hline North & 1,050 & -4 & -16 & -14 \\
\hline Northeast & 5,230 & -3 & -13 & -19 \\
\hline Central & 3,090 & -2 & -18 & -26 \\
\hline East & 6,185 & -1 & -12 & -15 \\
\hline Southwest & 1,565 & -5 & -20 & -21 \\
\hline South & 3,535 & -6 & -17 & -27 \\
\hline Southeast & 4,700 & -2 & -17 & -24 \\
\hline Entire State & 2,645 & -3 & -15 & -20 \\
\hline
\end{tabular}

Source: ${ }^{a}$ Annual UNL Nebraska Farm Real Estate Market Surveys, 2014, 2016, 2018, and 2019.

- Since the peak of 2014, the average market value of land in Nebraska has dropped about 20 percent across the state according to Table 2. At 26, 27, and 24 percent, the Central, South, and Southeast Districts displayed the largest declines over the past five years.

- Comparatively over the prior three years the market value of land has averaged about 15 percent lower. The Southwest District reported the highest decline at 20 percent since 2016.

Table 3. 2019 Values and Recent Trends by Land Class in Nebraska ${ }^{a}$

\begin{tabular}{|c|c|c|c|c|}
\hline Land Class & $\begin{array}{c}2019 \text { Average } \\
\text { Value }\end{array}$ & 1-Year Change & 3-Year Change & 5-Year Change \\
\hline & Dollars/Acre & ----------------. & ercent Change --- & ------------- \\
\hline \multicolumn{5}{|l|}{ Dryland Cropland } \\
\hline No Irrigation Potential & 3,040 & -2 & -12 & -18 \\
\hline Irrigation Potential & 4,010 & -3 & -16 & -23 \\
\hline \multicolumn{5}{|l|}{ Grassland } \\
\hline Tillable & 1,185 & -5 & -21 & -15 \\
\hline Nontillable & 795 & -5 & -18 & -8 \\
\hline \multicolumn{5}{|l|}{ Hayland } \\
\hline All Classes & 1,615 & -6 & -18 & -18 \\
\hline \multicolumn{5}{|l|}{ Irrigated Cropland } \\
\hline Gravity & 5,690 & -2 & -12 & -22 \\
\hline Center Pivot $^{\mathrm{b}}$ & 5,970 & -3 & -14 & -22 \\
\hline All-Land & 2,645 & -3 & -15 & -20 \\
\hline
\end{tabular}

Source: ${ }^{a}$ Annual UNL Nebraska Farm Real Estate Market Surveys, 2014, 2016, 2018, and 2019.

${ }^{\mathrm{b}}$ Value of pivot not included in per acre value.

- By land class, dryland cropland with irrigation potential reported the largest decline over the prior fiveyear period at 23 percent (Table 3). Irrigated cropland including center pivot and gravity noted a similar decline at 22 percent. The smallest drop in market value came from nontillable grassland at 8 percent.

- Over the three-year period, dryland and irrigated cropland noted smaller declines between 12 and 16 percent. The grassland and hayland land classes noted slightly higher drops at 18 to 21 percent. 


\section{Land Values Ranges}

In addition to the estimated average value of land, panel members reported high and low grade quality levels for each land class summarized in Table 4 . These averages create estimated quality value ranges for the different land classes in Nebraska.

Table 4. Average Reported Value Per Acre of Nebraska Farmland for Different Types and Grades of Land in Nebraska by Agricultural Statistics District, February 1, 2019a

\begin{tabular}{|c|c|c|c|c|c|c|c|c|}
\hline \multirow{2}{*}{$\begin{array}{l}\text { Type of Land } \\
\text { and Grade }\end{array}$} & \multicolumn{8}{|c|}{ Agricultural Statistics District } \\
\hline & Northwest & North & Northeast & Central & East & Southwest & South & Southeast \\
\hline & \multicolumn{8}{|c|}{ 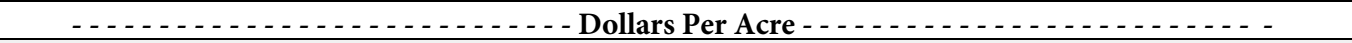 } \\
\hline \multicolumn{9}{|c|}{ Dryland Cropland (No Irrigation Potential) } \\
\hline Average & 645 & 1,495 & 5,300 & 2,755 & 5,765 & 1,445 & 2,880 & 4,130 \\
\hline High Grade & 820 & 1,845 & 6,420 & 3,155 & 6,870 & 1,620 & 3,300 & 5,100 \\
\hline Low Grade & 475 & 1,285 & 3,960 & 2,030 & 4,450 & 1,010 & 2,165 & 2,940 \\
\hline \multicolumn{9}{|c|}{ Dryland Cropland (Irrigation Potential) } \\
\hline Average & 680 & 1,915 & 5,640 & 3,055 & 6,145 & 1,585 & 3,450 & 5,265 \\
\hline High Grade & 870 & 2,265 & 6,310 & 3,515 & 7,000 & 1,760 & 4,140 & 6,175 \\
\hline Low Grade & 505 & 1,715 & 4,745 & 2,380 & 4,865 & 1,325 & 2,810 & 3,905 \\
\hline \multicolumn{9}{|c|}{ Grazing Land (Tillable) } \\
\hline Average & 500 & 1,040 & 3,125 & 1,750 & 3,075 & 880 & 1,875 & 2,760 \\
\hline High Grade & 605 & 1,265 & 3,715 & 2,175 & 3,910 & 1,060 & 2,110 & 3,125 \\
\hline Low Grade & 420 & 945 & 2,490 & 1,500 & 2,420 & 785 & 1,485 & 2,140 \\
\hline \multicolumn{9}{|c|}{ Grazing Land (Nontillable) } \\
\hline Average & 410 & 625 & 1,995 & 1,405 & 2,255 & 735 & 1,335 & 1,970 \\
\hline High Grade & 550 & 870 & 2,670 & 1,765 & 2,600 & 820 & 1,725 & 2,120 \\
\hline Low Grade & 360 & 500 & 1,680 & 1,050 & 1,885 & 610 & 1,215 & 1,740 \\
\hline \multicolumn{9}{|l|}{ Hayland } \\
\hline Average & 710 & 1,140 & 3,020 & 1,885 & 3,040 & 1,255 & 1,990 & 2,645 \\
\hline High Grade & 815 & 1,390 & 3,630 & 2,040 & 3,335 & 1,490 & 2,600 & 3,315 \\
\hline Low Grade & 520 & 1,000 & 2,225 & 1,560 & 2,415 & 1,040 & 1,415 & 2,025 \\
\hline \multicolumn{9}{|c|}{ Gravity Irrigated Cropland } \\
\hline Average & 2,245 & 3,570 & 6,510 & 5,860 & 7,585 & 3,700 & 5,365 & 5,900 \\
\hline High Grade & 2,980 & 4,080 & 7,940 & 6,415 & 8,500 & 4,235 & 6,520 & 7,120 \\
\hline Low Grade & 1,710 & 2,700 & 5,610 & 4,875 & 6,340 & 2,990 & 4,185 & 4,870 \\
\hline \multicolumn{9}{|c|}{ Center Pivot Irrigated Cropland ${ }^{b}$} \\
\hline Average & 2,565 & 3,905 & 7,210 & 6,390 & 8,485 & 4,110 & 6,150 & 7,470 \\
\hline High Grade & 3,105 & 4,975 & 8,240 & 7,190 & 9,520 & 4,890 & 7,395 & 8,430 \\
\hline Low Grade & 2,060 & 3,380 & 5,910 & 5,195 & 6,985 & 3,615 & 5,625 & 6,105 \\
\hline
\end{tabular}

Source: ${ }^{a}$ UNL Nebraska Farm Real Estate Market Survey, 2019.

${ }^{\mathrm{b}}$ Value of pivot not included in per acre value.

- Reporting panel members indicated demand for high and low grade properties significantly varied depending upon the location of the property in Nebraska (Table 4). As a result, the spread on land grades varied through Nebraska given local demand and geographical features.

- Higher declines were reported in the Northwest, North, and Southwest Districts of Nebraska for the low grade land classes. Dryland cropland with irrigation potential, grassland nontillable, and hayland were the low grade land classes recording the highest rate of declines for these districts.

- The financial health of current owners coupled with current crop prices and commodity prices form a challenging circumstance for many operators in Nebraska and may be capitalized into real estate markets during future production years according to panel members. 


\section{Net Rates of Return to Agricultural Land}

The net rates of return to agricultural land give an estimate on the net income earning potential relative to the value of the asset. Table 5 reports the estimated net rates of return for dryland cropland, irrigated cropland, and grazing land in Nebraska.

Table 5. Estimated Annual Net Rates of Return by Type of Land and Agricultural Statistics District, Selected Years 2015-2019 ${ }^{\text {ab }}$

\begin{tabular}{|c|c|c|c|c|c|c|c|c|c|}
\hline \multirow{2}{*}{$\begin{array}{c}\text { Type of Land } \\
\text { and Year }\end{array}$} & \multicolumn{8}{|c|}{ Agricultural Statistics District } & \multirow{2}{*}{$\begin{array}{c}\text { State } \\
\text { Average }\end{array}$} \\
\hline & Northwest & North & Northeast & Central & East & Southwest & South & Southeast & \\
\hline & \multicolumn{9}{|c|}{\begin{tabular}{|c|c}
- & - \\
\end{tabular}} \\
\hline \multicolumn{10}{|c|}{ Dryland Cropland } \\
\hline 2015 & 3.4 & 2.4 & 2.9 & 2.4 & 2.6 & 2.5 & 2.3 & 2.4 & 2.6 \\
\hline 2016 & 3.6 & 2.5 & 3.0 & 2.7 & 2.6 & 2.4 & 2.2 & 2.5 & 2.7 \\
\hline 2017 & 3.5 & 2.4 & 2.8 & 2.5 & 2.3 & 2.5 & 2.2 & 2.4 & 2.6 \\
\hline 2018 & 3.3 & 2.5 & 2.7 & 2.6 & 2.2 & 2.4 & 2.4 & 2.3 & 2.5 \\
\hline 2019 & 3.1 & 2.4 & 2.6 & 2.5 & 2.4 & 2.2 & 2.3 & 2.2 & 2.5 \\
\hline \multicolumn{10}{|c|}{ Irrigated Cropland } \\
\hline 2015 & 4.4 & 2.6 & 3.5 & 2.4 & 3.0 & 3.3 & 2.4 & 2.8 & 3.1 \\
\hline 2016 & 4.3 & 2.5 & 3.6 & 2.6 & 2.9 & 3.2 & 2.3 & 2.8 & 3.0 \\
\hline 2017 & 4.0 & 2.6 & 3.4 & 2.7 & 2.8 & 3.1 & 2.4 & 2.7 & 3.0 \\
\hline 2018 & 3.9 & 2.7 & 3.2 & 2.5 & 2.7 & 3.1 & 2.5 & 2.6 & 2.9 \\
\hline 2019 & 3.6 & 2.6 & 3.1 & 2.4 & 2.5 & 2.9 & 2.4 & 2.5 & 2.8 \\
\hline \multicolumn{10}{|l|}{ Grazing Land } \\
\hline 2015 & 2.3 & 2.6 & 2.7 & 2.1 & 2.2 & 2.6 & 2.2 & 1.7 & 2.3 \\
\hline 2016 & 2.2 & 2.7 & 2.6 & 2.1 & 2.0 & 2.3 & 2.1 & 1.5 & 2.2 \\
\hline 2017 & 2.1 & 2.5 & 2.4 & 2.0 & 1.7 & 2.1 & 1.9 & 1.6 & 2.0 \\
\hline 2018 & 2.1 & 2.6 & 2.2 & 1.9 & 1.8 & 2.0 & 1.8 & 1.7 & 2.0 \\
\hline 2019 & 2.0 & 2.3 & 2.1 & 1.7 & 1.8 & 1.9 & 2.0 & 1.6 & 1.9 \\
\hline
\end{tabular}

Source: ${ }^{a}$ UNL Nebraska Farm Real Estate Market Surveys, 2015-2019.

${ }^{b}$ Panel members reported estimates of annual net returns as percentage rates of current land values. Real estate appraisers refer to this percentage as the market-derived capitalization rate.

- In 2019, the net rates or return (market-derived capitalization rates) reported slight declines across Nebraska (Table 5). Lower net returns on agricultural land coupled with high landownership expenses for the investment led to stagnant capitalization rates.

- One of the most negative forces weighing on net returns comes from property taxes according to panel members. As land transitions between parties, low capitalization rates may lead the next generation to consider alternative investments or assets outside of the state.

- Capitalization rates varied from 1.6 to 3.6 percent for agricultural land across Nebraska. Grazing land tended to report the lowest rates, from 1.6 to 2.3 percent. Irrigated cropland reported returns from 2.4 to 3.6 percent and dryland averaged from 2.2 to 3.1 percent. 
Figure 4. Historical Estimated Annual Net Rates of Return by Land Type in Nebraska, Selected Years 1991-2019a

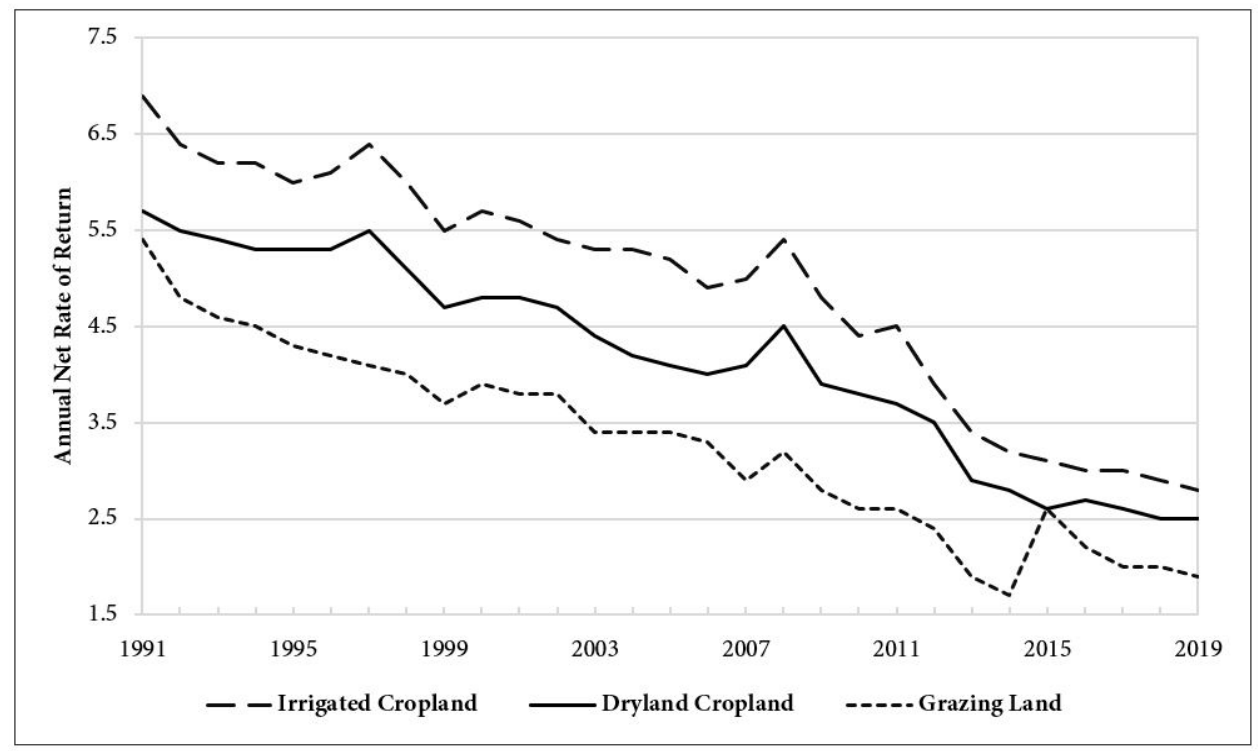

Source: a UNL Nebraska Farm Real Estate Market Surveys, 1991-2019.

- In 2019 the net rate of returns dropped by 0.1 percent for irrigated cropland to 2.8 percent and grazing land to 1.9 percent, while dryland cropland remained unchanged at 2.5 percent (Table 5). These averages continued the slightly negative trend of prior years.

- Short- and long-term interest rates in the United States remained steady in 2019 as the Federal Reserve System has not made major changes to fiscal policy. Concerns among panel members indicated trade issues may persist placing pressure on prices for critical commodities. Coupling these two forces may make alternative investments to agricultural land more appealing unless rates change.

- In periods of low rates of return, alternative investments may become more appealing for market participants looking for a store of wealth. The prolonged period of low capitalization rates on land might make certain investment alternatives more appealing to absentee landowners across Nebraska as their direct connection to the asset becomes more distant or fractionalized. 


\section{Factors Influencing Current Agricultural Land Markets}

Many economic factors contribute to the changes in agricultural land values during 2019. Figure 5 ranks and summarizes these factors based upon panel members' observations on their influences on land markets.

Figure 5. Reporters' Rating of Factors Influencing Agricultural Land Values in Their Areas of Nebraska, February 2019

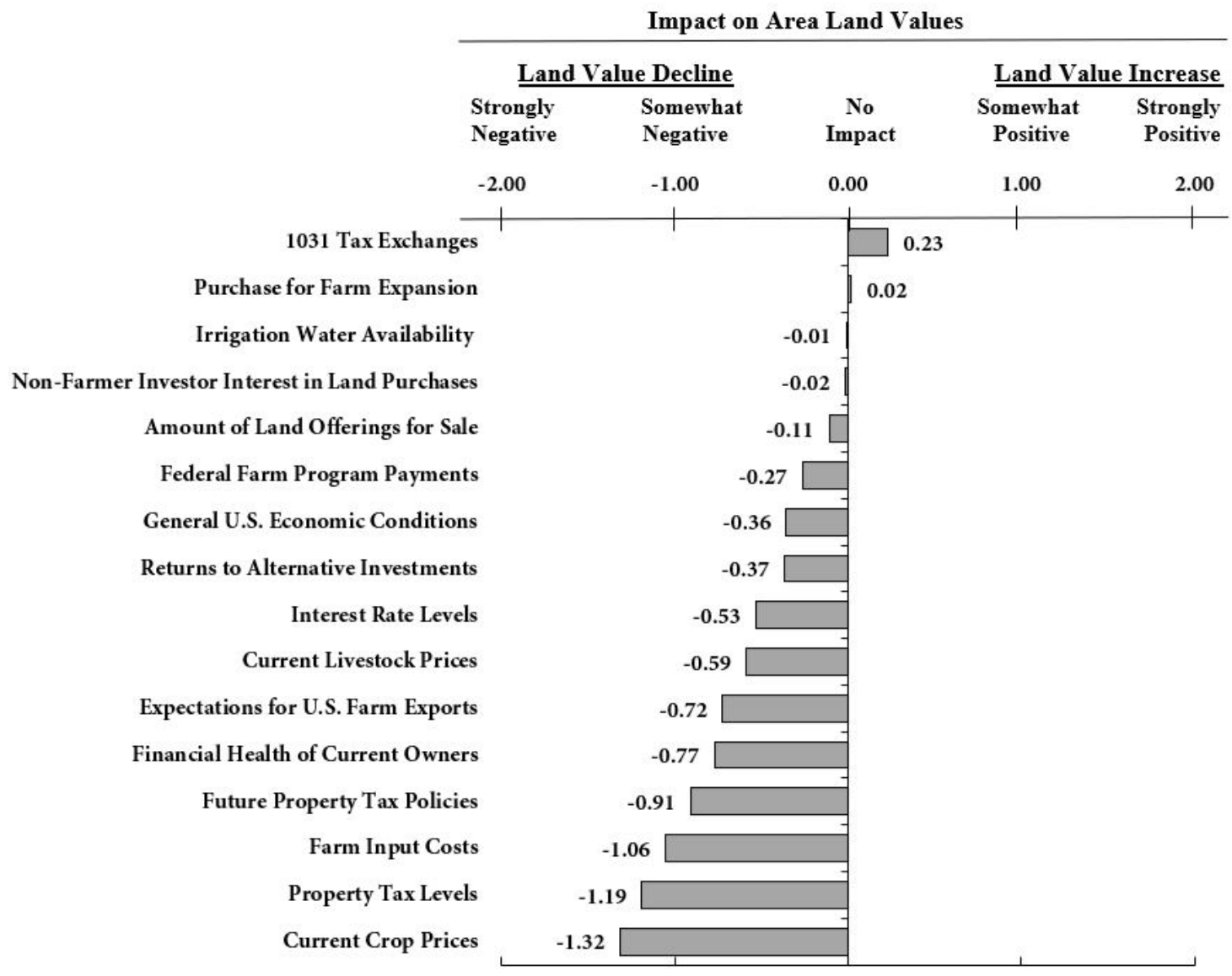

Source: UNL Nebraska Farm Real Estate Market Survey, 2019.

- For the second year in a row, current crop prices, property tax levels, and farm input costs ranked as the most negative forces influencing land according to panel members (Figure 5). These major economic factors directly influence enterprise profitability. The fourth and fifth most negative features also influencing finances included future property tax policies and financial health of current owners.

- The only two slightly positive factors influencing the market value of land included 1031 tax exchanges and purchases for farm expansion. The overall outlook on the market value of land across Nebraska appears strained and might be restricting the number of land sales coming to market.

- The Nebraska Unicameral has put forward various policy proposals attempting to address current property tax levels on agricultural land. Panel members indicate a strong desire to see reforms in future property tax policies to remediate this issue faced by owners of agricultural land. 


\section{Characteristics of 2018 Land Market Transactions}

Each year panel members provide specific details on actual land transactions considered to be representative of their local markets. Panel members reported details on 529 farm real estate transactions for 2018 in Nebraska and these transactions are reported in Tables $6,7,8$, and 9.

Table 6. Land Characteristics of 2018 Agricultural Real Estate Transactions, by Agricultural Statistics District in Nebraska

\begin{tabular}{|c|c|c|c|c|c|c|}
\hline \multirow{2}{*}{$\begin{array}{c}\text { Agricultural } \\
\text { Statistics District }\end{array}$} & \multirow{2}{*}{$\begin{array}{c}\text { Average Size } \\
\text { of Tract }\end{array}$} & \multicolumn{3}{|c|}{ Average Percent Distribution } & \multicolumn{2}{|c|}{ Average Price } \\
\hline & & $\begin{array}{c}\text { Dryland } \\
\text { Cropland }\end{array}$ & $\begin{array}{l}\text { Irrigated } \\
\text { Cropland }\end{array}$ & Pasture & Per Acre & Per Tract \\
\hline & - - - Acres - - - & \multicolumn{3}{|c|}{ 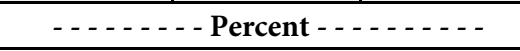 } & \multicolumn{2}{|c|}{ - . - - - Dollars - . - . - } \\
\hline Northwest & 686 & 17 & 15 & 68 & 841 & 576,878 \\
\hline North & 1,274 & 3 & 20 & 77 & 1,053 & $1,341,537$ \\
\hline Northeast & 143 & 66 & 21 & 13 & 5,847 & 833,418 \\
\hline Central & 237 & 6 & 44 & 49 & 3,824 & 906,761 \\
\hline East & 107 & 47 & 40 & 13 & 6,655 & 712,760 \\
\hline Southwest & 333 & 26 & 19 & 55 & 1,639 & 546,214 \\
\hline South & 146 & 39 & 27 & 34 & 3,486 & 509,300 \\
\hline Southeast & 141 & 52 & 31 & 17 & 4,991 & 701,789 \\
\hline State & 221 & 31 & 26 & 43 & 3,423 & 757,069 \\
\hline
\end{tabular}

Source: Based on 529 transactions which occurred across Nebraska during 2018 and reported in the UNL Nebraska Farm Real Estate Market Survey, 2019.

- The average parcel size of agricultural ground sold in Nebraska during 2018 was 221 acres according to Table 6. For Nebraska the average price per acre of $\$ 3,423$ equated to a parcel sale price of $\$ 757,069$. The highest price per acre sales were reported in the Northeast and East Districts at $\$ 5,847$ and $\$ 6,655$ per acre. Lower prices occurred in the Northwest and North Districts at \$841 and \$1,053 per acre.

- The average tract size for land transactions across the state reflected the underlying agricultural practices of the area. In 2019 the largest size tracts of land ranged from 686 acres in the Northwest to 1,274 acres in the North. Across the other size districts averaged between about 100 to 150 acres except in the Southwest reporting an average of 333 acres.

- The largest increase in percentage of land sold by type from 2017 to 2018 was irrigated cropland pasture in the North District. For 2018, 20 percent of the land sold in the North District was pasture compared to 3 percent in 2017.

- The largest decrease in percentage of land sold by type from 2017 to 2018 was pasture in the North District. In 2018, 77 percent of the land sold in the North District was dry cropland pasture compared to 94 percent in 2016. 
Table 7. Types of Financing Associated with 2018 Agricultural Real Estate Sales, by Agricultural Statistics District in Nebraska

\begin{tabular}{l|c|c|c|c|}
\hline \multirow{1}{*}{$\begin{array}{c}\text { Agricultural } \\
\text { Statistics District }\end{array}$} & \multicolumn{4}{c|}{ Financing of Purchase } \\
\cline { 2 - 5 } Northwest & Cash Purchase & Mortgage & Contract For Deed & Other \\
\cline { 2 - 5 } North & 62 & 38 & 0 & 0 \\
Northeast & 65 & 30 & 5 & 0 \\
Central & 41 & 50 & 7 & 2 \\
East & 42 & 56 & 0 & 2 \\
Southwest & 62 & 35 & 4 & 3 \\
South & 11 & 85 & 0 & 0 \\
Southeast & 64 & 36 & 1 & 0 \\
\hline State & 61 & 37 & $\mathbf{2}$ & $\mathbf{2}$ \\
\hline
\end{tabular}

Source: Based on 529 transactions which occurred across Nebraska during 2018 and reported in the UNL Nebraska Farm Real Estate Market Survey, 2019.

- Cash sales for land purchases picked up as mortgages decreased in 2018 (Table 7). Cash purchases increased from 50 to 53 percent while mortgages declined from 48 to 43 percent.

- Contract for deed and other sources remain a very low means of purchasing or financing land as each only accounted for 2 percent of transactions. Cash purchases and mortgages provide the dominant form of financing in land transactions.

Table 8. Percent Distribution of Agricultural Real Estate Transactions in 2018 by Buyer Type, by Agricultural Statistics District in Nebraska

\begin{tabular}{|c|c|c|c|c|}
\hline \multirow{2}{*}{$\begin{array}{c}\text { Agricultural } \\
\text { Statistics District }\end{array}$} & \multicolumn{4}{|c|}{ Type of Buyer } \\
\hline & $\begin{array}{c}\text { Active } \\
\text { Farmer/Rancher }\end{array}$ & $\begin{array}{c}\text { Local } \\
\text { Non-Farmer }\end{array}$ & $\begin{array}{c}\text { Non-Local Nebraska } \\
\text { Resident }\end{array}$ & $\begin{array}{c}\text { Out-of-State } \\
\text { Buyer }\end{array}$ \\
\hline & \multicolumn{4}{|c|}{ 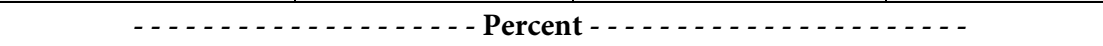 } \\
\hline Northwest & 77 & 4 & 4 & 15 \\
\hline North & 75 & 15 & 5 & 5 \\
\hline Northeast & 75 & 14 & 7 & 4 \\
\hline Central & 81 & 12 & 5 & 2 \\
\hline East & 75 & 20 & 3 & 3 \\
\hline Southwest & 81 & 11 & 4 & 4 \\
\hline South & 73 & 9 & 18 & 0 \\
\hline Southeast & 83 & 15 & 2 & 1 \\
\hline State & 78 & 15 & 4 & 3 \\
\hline
\end{tabular}

- Land purchases made by Nebraska residents whom were either active farmers and ranchers or local nonfarmers comprised 78 and 15 percent of sales in 2018 as shown in Table 8. Combined, these two categories accounted for 93 percent of land transactions reported by panel members.

- Non-local Nebraska residents and out of state buyers accounted for 7 percent of agricultural land transactions in 2019. The Northwest District once again reported the highest rate of out-of-state buyers. 
Table 9. Percent Distribution of Agricultural Real Estate Transactions in 2018 by Seller Type, by Agricultural Statistics District in Nebraska

\begin{tabular}{|c|c|c|c|c|c|c|}
\hline \multirow{2}{*}{$\begin{array}{c}\text { Agricultural } \\
\text { Statistics } \\
\text { District }\end{array}$} & \multicolumn{6}{|c|}{ Type of Seller } \\
\hline & $\begin{array}{l}\text { Active } \\
\text { Farmer }\end{array}$ & $\begin{array}{l}\text { Quitting } \\
\text { Farmer }\end{array}$ & Estate & $\begin{array}{c}\text { Local } \\
\text { Non-Farmer }\end{array}$ & $\begin{array}{c}\text { Non-Local NE } \\
\text { Resident }\end{array}$ & $\begin{array}{c}\text { Out-of-State } \\
\text { Resident }\end{array}$ \\
\hline & \multicolumn{6}{|c|}{ 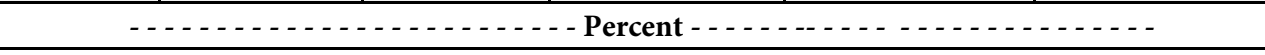 } \\
\hline Northwest & 38 & 12 & 31 & 4 & 4 & 12 \\
\hline North & 40 & 20 & 20 & 10 & 0 & 10 \\
\hline Northeast & 10 & 4 & 53 & 17 & 2 & 13 \\
\hline Central & 28 & 12 & 37 & 7 & 5 & 12 \\
\hline East & 26 & 2 & 38 & 21 & 1 & 11 \\
\hline Southwest & 22 & 22 & 22 & 11 & 7 & 15 \\
\hline South & 0 & 9 & 45 & 0 & 0 & 45 \\
\hline Southeast & 37 & 5 & 35 & 16 & 3 & 5 \\
\hline State & 26 & 6 & 39 & 15 & 3 & 11 \\
\hline
\end{tabular}

Source: Based on 529 transactions which occurred across Nebraska during 2018 and reported in the UNL Nebraska Farm Real Estate Market Survey, 2019.

- Approximately 80 percent of agricultural land sales in 2018 came from active farmers, estates, and local non farmers (Table 9). The remaining 20 percent came from those quitting farming, non-local Nebraska residents, and out-of-state residents.

- Estate sales, at 39 percent, comprised the largest share of land transactions across the state in 2018. In many rural areas the aging population may contribute a significant number of estate sales to markets transactions in the future.

- Despite the financial challenges faced by many operators across Nebraska the percent of agricultural sales did not increase significantly from active or quitting farmers. The percent of active farmer sales has fluctuated around 20 to 25 percent over the prior three years. 


\section{Cash Rental Rates}

Cash rental rates once again on average trended down across Nebraska for the 2019 growing year. By land Table 10 summarizes average cash rental rates for 2019, percent changes from the prior year, and the high and low third quality grade averages.

Table 10. Reported Cash Rental Rates for Various Types of Nebraska Farmland and Pasture: 2019 Averages, Percent Change from 2018 and Quality Ranges by Agricultural Statistics District ${ }^{\mathrm{a}}$

\begin{tabular}{|c|c|c|c|c|c|c|c|c|}
\hline \multirow{2}{*}{ Type of Land } & \multicolumn{8}{|c|}{ Agricultural Statistics District } \\
\hline & Northwest & North & Northeast & Central & East & Southwest & South & Southeast \\
\hline \multicolumn{9}{|c|}{ 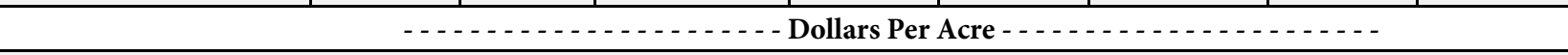 } \\
\hline \multicolumn{9}{|l|}{ Dryland Cropland } \\
\hline Average .............................. & 27 & 50 & 205 & 84 & 200 & 38 & 73 & 155 \\
\hline \% Change...................... & -4 & -6 & -2 & -5 & 5 & -7 & -4 & -3 \\
\hline High Third Quality... & 40 & 74 & 245 & 110 & 230 & 55 & 105 & 185 \\
\hline Low Third Quality..... & 21 & 36 & 170 & 67 & 160 & 31 & 47 & 125 \\
\hline \multicolumn{9}{|l|}{ Gravity Irrigated Cropland } \\
\hline Average & 110 & 165 & 255 & 195 & 245 & 155 & 190 & 220 \\
\hline \% Change .......................... & -4 & -3 & 2 & -5 & -4 & -6 & -5 & -2 \\
\hline High Third Quality... & 135 & 190 & 285 & 245 & 285 & 195 & 230 & 260 \\
\hline Low Third Quality..... & 88 & 115 & 215 & 160 & 210 & 120 & 155 & 185 \\
\hline \multicolumn{9}{|c|}{ Center Pivot Irrigated Cropland ${ }^{b}$} \\
\hline Average & 145 & 185 & 280 & 215 & 285 & 175 & 205 & 250 \\
\hline \% Change ....................... & -3 & -8 & -3 & -2 & 2 & -8 & -5 & -4 \\
\hline High Third Quality... & 180 & 225 & 325 & 260 & 325 & 220 & 250 & 300 \\
\hline Low Third Quality..... & 110 & 140 & 240 & 175 & 240 & 150 & 185 & 205 \\
\hline \multicolumn{9}{|l|}{ Pasture } \\
\hline 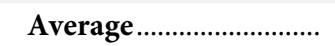 & 11 & 24 & 59 & 31 & 47 & 19 & 34 & 46 \\
\hline \% Change................... & 1 & -6 & -4 & -5 & -3 & -7 & -5 & -1 \\
\hline High Third Quality... & 18 & 38 & 77 & 43 & 66 & 27 & 39 & 61 \\
\hline Low Third Quality..... & 8 & 13 & 41 & 25 & 38 & 15 & 24 & 39 \\
\hline
\end{tabular}

- Rental rates for dryland and irrigated cropland across Nebraska trended down across the majority of Nebraska according to Table 10. These declines ranged from around 2 to 8 percent with the exception of several small increases in dryland center pivot irrigated cropland in the East and gravity irrigated cropland in the Northeast.

- Productivity of the cropland including soil types, degree of slope, expected rainfall, and location all influence the competitiveness of rent paid in an area according to panel members. These differences by district provide the range and average paid in cash rent from the low third to high third quality.

- The rate of decline for the high third and low third quality of cash rent for dryland and irrigated cropland across the different types of land stayed fairly consistent for the eight districts.

- On a per acre basis pasture rents across Nebraska trended down from 1 to 7 percent except for the Northwest District which noted a small increase of 1 percent. Factors influencing pasture rental averages include stocking rates, geographical limitations, and overall range quality. 
Table 11. Reported Cash Rental Rates for Pasture on a Monthly Rate Basis for 2019: Averages and Ranges by Agricultural Statistics District ${ }^{\mathrm{a}}$

\begin{tabular}{|c|c|c|c|c|c|c|c|c|}
\hline \multirow{2}{*}{ Type } & \multicolumn{8}{|c|}{ Agricultural Statistics District } \\
\hline & Northwest & North & Northeast & Central & East & Southwest & South & Southeast \\
\hline \multicolumn{9}{|c|}{ - } \\
\hline \multicolumn{9}{|c|}{ Cow-Calf Pair Monthly Rates ${ }^{b}$} \\
\hline Average .............................. & 36.15 & 57.50 & 54.90 & 50.70 & 49.15 & 46.35 & 44.10 & 45.15 \\
\hline High Third Quality... & 46.75 & 70.95 & 72.60 & 62.25 & 63.00 & 58.20 & 57.55 & 55.80 \\
\hline Low Third Quality..... & 27.10 & 47.45 & 42.35 & 39.55 & 43.75 & 40.45 & 36.95 & 34.60 \\
\hline \multicolumn{9}{|c|}{ Stocker (500-600 lb.) Monthly Rates } \\
\hline 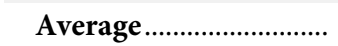 & 22.80 & 33.55 & 37.40 & 30.85 & 36.05 & 34.65 & 31.30 & 35.25 \\
\hline High Third Quality... & 29.20 & 41.00 & 45.65 & 40.40 & 43.75 & 40.90 & 37.85 & 42.40 \\
\hline Low Third Quality..... & 17.85 & 27.90 & 28.60 & 24.15 & 28.35 & 27.70 & 26.50 & 25.70 \\
\hline
\end{tabular}

- Cow-calf pair and stock rental rates trended slightly lower across Nebraska in 2019 according to Table 11. Rental rates for cow-calf pairs or stockers represent the typical grazing fee for one month during the summer growing season. The monthly rates would typically be multiplied by five months for a grazing season fee.

- Negotiations on contractual terms for the grazing season include considerations on the landlord and tenant's willingness to provide fencing maintenance, weed or brush control, and monitoring or providing water. Depending upon the willingness of either party to maintain, control, or provide these resources as part of the lease, the final rental rate may vary accordingly as panel members noted.

- In addition, panel members also reported on the need for reviewing leases to account for different kinds of weather-related disasters such as flooding or drought. Reviewing these provisions by the appropriate agency or organization providing disaster assistance ensures compliance on grazing land in the case of an adverse weather event. 


\section{Special Feature: Cover Crop Utilization Across Nebraska and Implications for Cropland Lease Arrangements in 2019}

Each year the special feature section covers topics on new or emerging issues related to the agricultural land industry in Nebraska. These topics reflect interest expressed by panel members and readership of the Nebraska Farm Real Estate Market Highlights Reports. The special feature section in 2019 focuses on trends and considerations for cover crops across Nebraska and implications on lease arrangements.

Findings from the 2017 Census of Agriculture in Table 12 provide an overview on the utilization of cover crops across the eight districts of the state (USDA-NASS, 2019). Approximately 748 thousand acres of cover crops were grown on about 22 million acres of cropland across Nebraska in 2017. Cover crops were planted on about 3.4 percent of cropland acres across the state by 4,419 operators.

Table 12. Cover Crop Practices for Cropland and Operators in 2017, by Agricultural Statistics District in Nebraska ${ }^{a}$

\begin{tabular}{|c|c|c|c|c|c|c|}
\hline \multirow{2}{*}{$\begin{array}{c}\text { Agricultural } \\
\text { Statistics } \\
\text { District }\end{array}$} & \multicolumn{2}{|c|}{ Planted Acres } & \multirow{2}{*}{$\begin{array}{l}\text { Cropland Acres } \\
\text { Planted to } \\
\text { Cover Crops }\end{array}$} & \multicolumn{2}{|c|}{ Number of Operators } & \multirow{2}{*}{$\begin{array}{c}\text { Cropland } \\
\text { Operators Planted } \\
\text { Cover Crops }\end{array}$} \\
\hline & Cover Crops & Cropland & & $\begin{array}{c}\text { Planted } \\
\text { Cover Crops }\end{array}$ & $\begin{array}{c}\text { Planted } \\
\text { Cropland }\end{array}$ & \\
\hline & \multicolumn{2}{|c|}{ - . . - - Acres - . . - - } & - - - Percent - - - & \multicolumn{2}{|c|}{ - - - - - Number - . . - - } & - - - Percent - - - \\
\hline Northwest & 52,884 & $2,904,637$ & 1.8 & 274 & 3,682 & 7.4 \\
\hline North & 57,989 & $1,820,397$ & 3.2 & 306 & 2,686 & 11.4 \\
\hline Northeast & 133,885 & $3,630,051$ & 3.7 & 960 & 6,717 & 14.3 \\
\hline Central & 98,485 & $2,048,103$ & 4.8 & 585 & 3,949 & 14.8 \\
\hline East & 186,216 & $4,214,043$ & 4.4 & 1,102 & 9,695 & 11.4 \\
\hline Southwest & 60,853 & $2,489,757$ & 2.4 & 265 & 2,686 & 9.9 \\
\hline South & 83,247 & $1,878,089$ & 4.4 & 343 & 2,431 & 14.1 \\
\hline Southeast & 73,203 & $3,257,522$ & 2.2 & 584 & 6,238 & 9.4 \\
\hline State $^{b}$ & 747,903 & $22,242,599$ & 3.4 & 4,419 & 38,084 & 11.6 \\
\hline
\end{tabular}

Source: ${ }^{\text {a }} 2017$ Census of Agriculture, National Agricultural Statistical Service, USDA.

${ }^{\mathrm{b}}$ District values may not sum to state totals due to county-level disclosure.

- In 2017 across Nebraska about 38 thousand operators grew crops on about 22 million acres of land. The number of cropland acres in each district greatly varied across the state.

- Utilization of cover crops greatly varied across the eight regions. Arid areas such as the Northwest, North, and Southwest Districts tended to grow around 50 thousand acres. The Northeast, Central and East Districts each planted around 100,000 acres or more of cover crops.

- The number of operators in each of these regions planting cover crops also varied. In percentage terms, the cropland operators planting cover crops varied from a low of 7.4 percent in the Northwest District compared to a high 14.8 percent in the Central District.

When planting a cover crop across Nebraska, the motivation of the landowner or operator may vary depending upon the needs of the region or management requirements. Increased interest for cover crops in recent years has come from the perceived benefits to the land and mitigation of environmental issues. The underlying motivation for utilizing cover crops remain important as the operator may incur additional establishment and termination expenses for the land. Figure 6 summarizes the major reasons for planting of cover crops across Nebraska. 
Figure 6. Reasons for Planting Cover Crops on Cropland in Nebraska

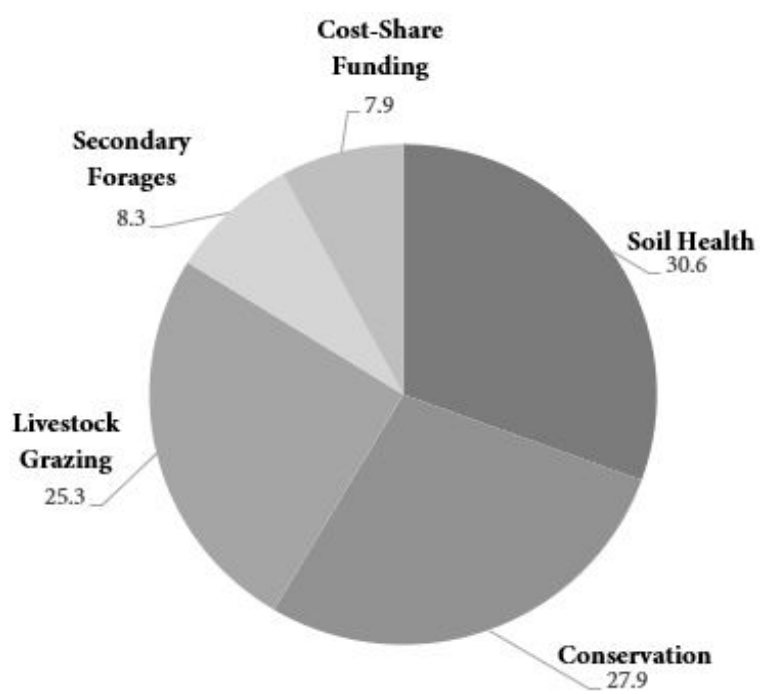

Source: UNL Nebraska Farm Real Estate Market Survey, 2019.

- In Figure 6 panel members reported environmental benefits such as soil health and conservation accounted for nearly 60 percent of the reasoning or motivation behind utilizing cover crops.

- Livestock grazing and use as a secondary forage in a rotation accounted for an additional 33.6 percent of the reasoning for planting a cover crop on an agricultural property. An ability to obtain cost-share funding only attributed to about 8 percent of the motivation behind adopting this practice.

Division of cover crop establishment expenses remain a provision to consider in a cropland lease arrangement. Benefits from utilizing a cover crop may exceed the length of the current lease. Figure 7 summarizes the dollar per acre rental discount on a cropland lease provided to a tenant when planting a cover crop.

Figure 7. Rental Discount in Dollars per Acre on Land Lease When Tenant Plants Cover Crops in Nebraska

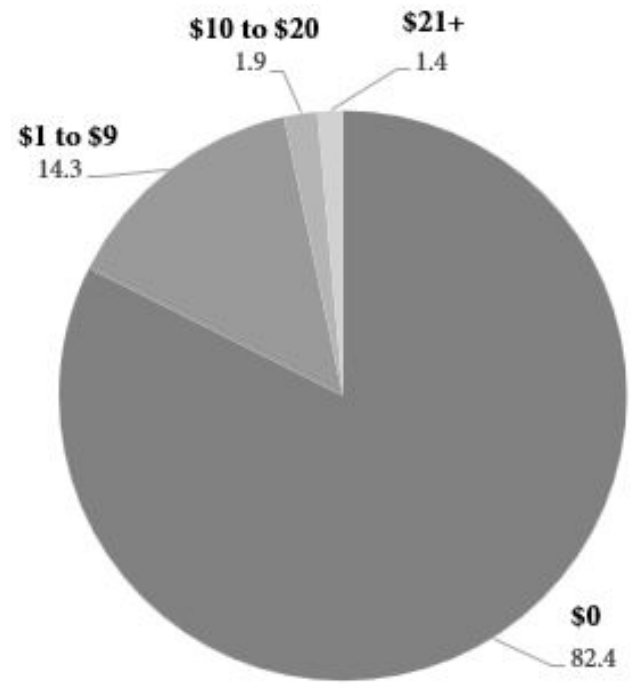

Source: UNL Nebraska Farm Real Estate Market Survey, 2019.

- In Figure 7 panel members indicated slightly over 80 percent of land leases do not provide a discount to tenants for planting cover crops. About 15 percent of leases provided a small discount between $\$ 1$ to $\$ 9$ per acre. Opportunities exist in lease negotiations to more equitability divide cover crop expenses. 
Statistical Appendix 
Appendix Table 1. Farm Real Estate Values in Nebraska, USDA Historical Series, 1860-2019a

\begin{tabular}{|c|c|c|c|c|c|c|}
\hline \multirow{2}{*}{ Year } & \multirow{2}{*}{$\begin{array}{l}\text { Number } \\
\text { of Farms }\end{array}$} & \multirow{2}{*}{$\begin{array}{c}\text { Land } \\
\text { in Farms }\end{array}$} & \multicolumn{3}{|c|}{ Value of Land \& Buildings } & \multirow{2}{*}{$\begin{array}{c}\text { Building } \\
\text { Value }\end{array}$} \\
\cline { 4 - 5 } & & Per Acre & Per Farm & Total Value & \\
\hline
\end{tabular}

Thousands Million Acres $\quad \underline{\text { Dollars }} \quad \underline{\text { Thousand Dollars }} \quad \underline{\text { Million Dollars }} \underline{\text { Million Dollars }}$

\begin{tabular}{|c|c|c|c|c|c|c|}
\hline 1860 & 2.8 & 1.0 & 6 & 1.4 & 6 & \\
\hline 1870 & 12.3 & 2.1 & 12 & 2.0 & 24 & \\
\hline 1880 & 63.4 & 9.9 & 11 & 1.7 & 106 & \\
\hline 1890 & 113.6 & 21.6 & 19 & 3.5 & 402 & \\
\hline 1900 & 121.5 & 29.9 & 19 & 4.8 & 578 & 91 \\
\hline 1910 & 129.7 & 38.6 & 47 & 14.0 & 1,813 & 199 \\
\hline 1911 & 129.2 & 39.0 & 48 & 14.4 & 1,864 & \\
\hline 1912 & 128.8 & 39.2 & 49 & 14.9 & 1,919 & \\
\hline 1913 & 128.2 & 39.5 & 50 & 15.4 & 1,974 & \\
\hline 1914 & 127.5 & 39.8 & 51 & 15.9 & 2,027 & \\
\hline 1915 & 126.9 & 40.3 & 50 & 15.9 & 2,017 & \\
\hline 1916 & 126.3 & 40.9 & 51 & 16.5 & 2,084 & \\
\hline 1917 & 125.8 & 41.5 & 54 & 17.8 & 2,240 & \\
\hline 1918 & 125.2 & 41.8 & 62 & 20.7 & 2,591 & \\
\hline 1919 & 123.1 & 41.9 & 71 & 23.8 & 2,978 & \\
\hline 1920 & 124.6 & 42.2 & 88 & 29.8 & 3,712 & 382 \\
\hline 1921 & 125.1 & 41.9 & 82 & 27.5 & 3,439 & \\
\hline 1922 & 137.1 & 41.9 & 71 & 21.7 & 2,974 & \\
\hline 1923 & 126.6 & 42.1 & 68 & 22.6 & 2,860 & \\
\hline 1924 & 127.3 & 41.8 & 63 & 20.7 & 2,635 & 398 \\
\hline 1925 & 127.5 & 42.1 & 60 & 19.8 & 2,524 & \\
\hline 1926 & 128.2 & 42.5 & 60 & 19.9 & 2,552 & \\
\hline 1927 & 128.5 & 43.2 & 58 & 19.5 & 2,505 & \\
\hline 1928 & 128.6 & 44.0 & 57 & 19.5 & 2,508 & \\
\hline 1929 & 128.9 & 44.3 & 57 & 19.6 & 2,526 & \\
\hline 1930 & 129.3 & 44.6 & 56 & 19.3 & 2,495 & 447 \\
\hline 1931 & 129.9 & 45.0 & 52 & 18.0 & 2,338 & \\
\hline 1932 & 130.8 & 45.8 & 44 & 15.4 & 2,015 & \\
\hline 1933 & 132.0 & 46.0 & 35 & 12.2 & 1,609 & \\
\hline 1934 & 133.2 & 46.4 & 35 & 12.2 & 1,625 & \\
\hline 1935 & 134.0 & 46.9 & 34 & 11.9 & 1,594 & 341 \\
\hline 1936 & 131.2 & 46.7 & 34 & 12.1 & 1,587 & \\
\hline 1937 & 128.5 & 47.4 & 32 & 11.8 & 1,516 & \\
\hline 1938 & 125.8 & 47.4 & 30 & 11.3 & 1,421 & \\
\hline 1939 & 123.6 & 46.8 & 28 & 10.6 & 1,310 & \\
\hline 1940 & 121.1 & 47.4 & 24 & 9.4 & 1,138 & 257 \\
\hline 1941 & 119.2 & 48.2 & 22 & 8.9 & 1,061 & \\
\hline 1942 & 116.9 & 48.2 & 24 & 9.9 & 1,157 & \\
\hline 1943 & 115.6 & 47.5 & 27 & 11.1 & 1,283 & \\
\hline 1944 & 113.7 & 47.9 & 33 & 13.9 & 1,580 & \\
\hline
\end{tabular}

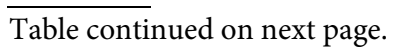


Appendix Table 1. Farm Real Estate Values in Nebraska, USDA Historical Series, 1860-2019a (continued)

\begin{tabular}{|c|c|c|c|c|c|c|}
\hline \multirow{2}{*}{ Year } & \multirow{2}{*}{$\begin{array}{l}\text { Number } \\
\text { of Farms }\end{array}$} & \multirow{2}{*}{$\begin{array}{c}\text { Land } \\
\text { in Farms }\end{array}$} & Per Acre & Per Farm & Total Value & \multirow{2}{*}{$\begin{array}{c}\text { Building } \\
\text { Value }\end{array}$} \\
\cline { 4 - 5 } & &
\end{tabular}

Thousands Million Acres $\quad$ Dollars $\quad$ Thousand Dollars $\quad$ Million Dollars $\quad$ Million Dollars

\begin{tabular}{|c|c|c|c|c|c|c|}
\hline 1945 & 111.4 & 47.6 & 37 & 15.8 & 1,760 & 382 \\
\hline 1946 & 111.3 & 47.4 & 42 & 17.9 & 1,992 & \\
\hline 1947 & 110.1 & 48.0 & 47 & 20.5 & 2,257 & \\
\hline 1947 & 109.0 & 47.3 & 56 & 24.3 & 2,649 & \\
\hline 1949 & 108.0 & 47.2 & 62 & 27.1 & 2,927 & \\
\hline 1950 & 109.0 & 48.4 & 58 & 25.6 & 2,789 & \\
\hline 1951 & 107.0 & 48.4 & 66 & 29.8 & 3,192 & 562 \\
\hline 1952 & 105.0 & 48.3 & 72 & 33.1 & 3,477 & 605 \\
\hline 1953 & 104.0 & 48.3 & 75 & 34.7 & 3,610 & 621 \\
\hline 1954 & 103.0 & 48.3 & 70 & 32.8 & 3,386 & 589 \\
\hline 1955 & 102.0 & 48.3 & 73 & 34.5 & 3,534 & 645 \\
\hline 1956 & 101.0 & 48.3 & 73 & 34.9 & 3,523 & 719 \\
\hline 1957 & 98.0 & 48.3 & 72 & 35.8 & 3,501 & 606 \\
\hline 1958 & 96.0 & 48.3 & 79 & 40.0 & 3,839 & 572 \\
\hline 1959 & 94.0 & 48.3 & 86 & 43.9 & 4,131 & 677 \\
\hline 1960 & 93.0 & 48.2 & 89 & 46.3 & 4,308 & 763 \\
\hline 1961 & 90.0 & 48.2 & 90 & 48.2 & 4,341 & 790 \\
\hline 1962 & 88.0 & 48.2 & 95 & 52.2 & 4,598 & 860 \\
\hline 1963 & 86.0 & 48.1 & 97 & 54.0 & 4,647 & 911 \\
\hline 1964 & 84.0 & 48.2 & 105 & 60.0 & 5,055 & 1,072 \\
\hline 1965 & 82.0 & 48.2 & 111 & 65.3 & 5,352 & 1,258 \\
\hline 1966 & 80.0 & 48.2 & 120 & 72.6 & 5,805 & 1,283 \\
\hline 1967 & 78.0 & 48.2 & 132 & 81.4 & 6,348 & 1,143 \\
\hline 1968 & 76.0 & 48.2 & 143 & 90.5 & 6,882 & 1,136 \\
\hline 1969 & 74.0 & 48.2 & 150 & 97.8 & 7,238 & 1,021 \\
\hline 1970 & 73.0 & 48.1 & 154 & 101.5 & 7,407 & 941 \\
\hline 1971 & 72.0 & 48.1 & 157 & 104.9 & 7,552 & 853 \\
\hline 1972 & 71.0 & 48.1 & 170 & 115.2 & 8,177 & 932 \\
\hline 1973 & 70.0 & 48.1 & 193 & 132.6 & 9,283 & 1,012 \\
\hline 1974 & 70.0 & 48.1 & 242 & 166.3 & 11,640 & 1,152 \\
\hline 1975 & 67.0 & 47.9 & 282 & 201.6 & 13,508 & 1,229 \\
\hline 1976 & 67.0 & 47.9 & 363 & 259.2 & 17,366 & 1,546 \\
\hline 1977 & 66.0 & 47.8 & 420 & 304.1 & 20,070 & 1,806 \\
\hline 1978 & 66.0 & 47.8 & 412 & 298.5 & 19,702 & 1,832 \\
\hline 1979 & 65.0 & 47.7 & 525 & 385.3 & 25,043 & 2,204 \\
\hline 1980 & 65.0 & 47.7 & 635 & 466.0 & 30,289 & 2,547 \\
\hline 1981 & 65.0 & 47.7 & 729 & 535.0 & 34,773 & 2,851 \\
\hline 1982 & 63.0 & 47.5 & 730 & 550.4 & 34,675 & 2,809 \\
\hline 1983 & 62.0 & 47.4 & 701 & 535.9 & 33,227 & 2,758 \\
\hline 1984 & 61.0 & 47.2 & 645 & 499.1 & 30,444 & 2,710 \\
\hline
\end{tabular}

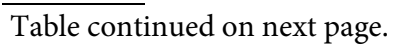


Appendix Table 1. Farm Real Estate Values in Nebraska, USDA Historical Series, 1860-2019a (continued)

\begin{tabular}{|c|c|c|c|c|c|c|}
\hline \multirow{2}{*}{ Year } & \multirow{2}{*}{$\begin{array}{l}\text { Number } \\
\text { of Farms }\end{array}$} & \multirow{2}{*}{$\begin{array}{c}\text { Land } \\
\text { in Farms }\end{array}$} & \multicolumn{3}{|c|}{ Value of Land \& Buildings } & \multirow{2}{*}{$\begin{array}{c}\text { Building } \\
\text { Value }\end{array}$} \\
\hline & & & Per Acre & Per Farm & Total Value & \\
\hline & Thousands & $\underline{\text { Million Acres }}$ & $\underline{\text { Dollars }}$ & Thousand Dollars & $\underline{\text { Million Dollars }}$ & $\underline{\text { Million Dollars }}$ \\
\hline 1985 & 60.0 & 47.2 & 485 & 381.9 & 22,911 & 2,474 \\
\hline 1986 & 59.0 & 47.2 & 416 & 332.7 & 19,629 & 2,532 \\
\hline 1987 & 59.0 & 47.2 & 400 & 320.1 & 18,885 & 2,682 \\
\hline 1988 & 58.0 & 47.1 & 457 & 371.1 & 21,525 & 3,186 \\
\hline 1989 & 57.0 & 47.1 & 511 & 422.2 & 24,068 & 3,451 \\
\hline 1990 & 57.0 & 47.1 & 524 & 433.0 & 24,680 & 3,186 \\
\hline 1991 & 56.0 & 47.1 & 517 & 434.8 & 24,350 & 2,978 \\
\hline 1992 & 56.0 & 47.1 & 517 & 434.8 & 24,350 & 3,026 \\
\hline 1993 & 56.0 & 46.5 & 514 & 426.8 & 23,901 & 3,022 \\
\hline 1994 & 56.0 & 46.5 & 550 & 456.7 & 25,575 & 2,966 \\
\hline 1995 & 56.0 & 46.4 & 580 & 480.6 & 26,912 & 3,041 \\
\hline 1996 & 56.0 & 46.4 & 610 & 505.4 & 28,304 & 3,099 \\
\hline 1997 & 55.0 & 46.4 & 620 & 523.1 & 28,768 & 3,049 \\
\hline 1998 & 55.0 & 46.4 & 645 & 544.1 & 29,928 & 3,068 \\
\hline 1999 & 54.0 & 46.3 & 675 & 578.8 & 31,253 & 3,094 \\
\hline 2000 & 52.0 & 46.1 & 710 & 629.4 & 32,731 & 3,126 \\
\hline 2001 & 50.0 & 46.0 & 735 & 676.2 & 33,810 & 3,111 \\
\hline 2002 & 49.4 & 45.9 & 760 & 706.2 & 34,884 & 3,087 \\
\hline 2003 & 48.5 & 45.9 & 775 & 733.5 & 35,573 & 3,024 \\
\hline 2004 & 48.3 & 45.8 & 810 & 768.1 & 37,098 & 3,023 \\
\hline 2005 & 48.0 & 45.7 & 910 & 866.4 & 41,587 & 3,168 \\
\hline 2006 & 47.6 & 45.7 & 1,030 & 988.9 & 47,071 & 3,507 \\
\hline 2007 & 47.7 & 45.6 & 1,140 & $1,089.8$ & 51,984 & 3,681 \\
\hline 2008 & 48.2 & 45.5 & 1,330 & $1,255.5$ & 60,515 & 3,909 \\
\hline 2009 & 48.6 & 45.5 & 1,320 & $1,235.8$ & 60,060 & 4,264 \\
\hline 2010 & 49.5 & 45.4 & 1,470 & $1,348.2$ & 66,738 & 4,738 \\
\hline 2011 & 49.7 & 45.4 & 1,840 & $1,680.8$ & 83,536 & 5,847 \\
\hline 2012 & 50.0 & 45.3 & 2,420 & $2,192.5$ & 109,626 & 7,674 \\
\hline 2013 & 49.4 & 45.3 & 2,800 & $2,567.6$ & 126,840 & 8,816 \\
\hline 2014 & 48.7 & 45.2 & 3,120 & $2,895.8$ & 141,024 & 9,731 \\
\hline 2015 & 48.0 & 45.2 & 3,050 & $2,872.1$ & 137,860 & 10,064 \\
\hline 2016 & 47.5 & 45.2 & 2,950 & $2,807.2$ & 133,340 & 9,568 \\
\hline 2017 & 46.3 & 45.2 & 2,900 & $2,831.1$ & 131,080 & 9,299 \\
\hline 2018 & 45.9 & 45.2 & 2,850 & $2,806.5$ & 128,820 & 9,083 \\
\hline $2019^{b}$ & 45.9 & 45.2 & 2,771 & $2,729.2$ & 125,268 & 8,791 \\
\hline
\end{tabular}

Source: a Farm Real Estate Historical Series Data: 1950-92, USDA, Economic Research Service, Sta. Bul. No. 855, May 1993 and earlier reports as well as recent electronic issues annually by Economic Research Service, U.S. Department of Agriculture.

${ }^{\mathrm{b}}$ Preliminary. 
Appendix Table 2. Deflated USDA Farmland Values and Percent Changes for Nebraska, 1930 to $2019^{a}$

\begin{tabular}{|c|c|c|c|c|}
\hline Year & $\begin{array}{c}\text { USDA Average } \\
\text { Value/Acre For Nebraska }\end{array}$ & $\begin{array}{c}1^{\text {st }} \text { Quarter GDP } \\
\text { Price Deflator } \\
(2019=100)\end{array}$ & $\begin{array}{l}\text { Deflated Average } \\
\text { Value/Acre }\end{array}$ & $\begin{array}{c}\text { Year-to-Year Change } \\
\text { Deflated Farmland in } \\
\text { Values }^{c}\end{array}$ \\
\hline 1930 & 56 & 8.16 & 686 & - \\
\hline 1931 & 52 & 7.32 & 711 & 3.5 \\
\hline 1932 & 44 & 6.45 & 682 & -4.1 \\
\hline 1933 & 35 & 6.28 & 558 & -18.2 \\
\hline 1934 & 35 & 6.63 & 528 & -5.3 \\
\hline 1935 & 34 & 6.77 & 503 & -4.8 \\
\hline 1936 & 34 & 6.84 & 497 & -1.1 \\
\hline 1937 & 32 & 7.14 & 448 & -9.8 \\
\hline 1938 & 30 & 6.93 & 433 & -3.4 \\
\hline 1939 & 28 & 6.86 & 408 & -5.8 \\
\hline 1940 & 24 & 6.94 & 346 & -15.2 \\
\hline 1941 & 22 & 7.40 & 297 & -14.0 \\
\hline 1942 & 24 & 7.98 & 301 & 1.2 \\
\hline 1943 & 27 & 8.41 & 321 & 6.7 \\
\hline 1944 & 33 & 8.61 & 383 & 19.4 \\
\hline 1945 & 37 & 8.84 & 419 & 9.2 \\
\hline 1946 & 42 & 9.90 & 424 & 1.3 \\
\hline 1947 & 47 & 10.94 & 430 & 1.3 \\
\hline 1948 & 56 & 11.65 & 481 & 11.9 \\
\hline 1949 & 62 & 11.94 & 519 & 8.0 \\
\hline 1950 & 58 & 11.75 & 494 & -4.9 \\
\hline 1951 & 66 & 12.72 & 519 & 5.2 \\
\hline 1952 & 72 & 12.95 & 556 & 7.1 \\
\hline 1953 & 75 & 13.15 & 570 & 2.6 \\
\hline 1954 & 70 & 13.30 & 526 & -7.7 \\
\hline 1955 & 73 & 13.42 & 544 & 3.3 \\
\hline 1956 & 73 & 13.85 & 527 & -3.0 \\
\hline 1957 & 72 & 14.35 & 502 & -4.9 \\
\hline 1958 & 79 & 14.71 & 537 & 7.1 \\
\hline 1959 & 86 & 14.95 & 575 & 7.1 \\
\hline 1960 & 89 & 15.15 & 588 & 2.1 \\
\hline 1961 & 90 & 15.31 & 588 & 0.0 \\
\hline 1962 & 95 & 15.52 & 612 & 4.2 \\
\hline 1963 & 97 & 15.68 & 619 & 1.1 \\
\hline 1964 & 105 & 15.90 & 660 & 6.7 \\
\hline 1965 & 111 & 16.16 & 687 & 4.1 \\
\hline 1966 & 120 & 16.51 & 727 & 5.8 \\
\hline 1967 & 132 & 17.02 & 776 & 6.7 \\
\hline 1968 & 143 & 17.65 & 810 & 4.4 \\
\hline 1969 & 150 & 18.46 & 813 & 0.3 \\
\hline
\end{tabular}

Table continued on next page. 
Appendix Table 2. Deflated USDA Farmland Values and Percent Changes for Nebraska, 1930 to $2019^{a}$ (continued)

\begin{tabular}{|c|c|c|c|c|}
\hline Year & $\begin{array}{c}\text { USDA Average } \\
\text { Value/Acre For Nebraska }\end{array}$ & $\begin{array}{c}1^{\text {st }} \text { Quarter GDP } \\
\text { Price Deflator } \\
(2019=100)\end{array}$ & $\begin{array}{l}\text { Deflated Average } \\
\text { Value/Acre }\end{array}$ & $\begin{array}{c}\text { Year-to-Year Change } \\
\text { Deflated Farmland in } \\
\text { Values }\end{array}$ \\
\hline 1970 & 154 & 19.47 & 791 & -2.7 \\
\hline 1971 & 157 & 20.47 & 767 & -3.0 \\
\hline 1972 & 170 & 21.45 & 793 & 3.4 \\
\hline 1973 & 193 & 22.32 & 865 & 9.1 \\
\hline 1974 & 242 & 24.01 & 1,008 & 16.6 \\
\hline 1975 & 282 & 26.63 & 1,059 & 5.1 \\
\hline 1976 & 363 & 28.26 & 1,284 & 21.3 \\
\hline 1977 & 420 & 29.91 & 1,404 & 9.3 \\
\hline 1978 & 412 & 31.82 & 1,295 & -7.8 \\
\hline 1979 & 525 & 34.27 & 1,532 & 18.3 \\
\hline 1980 & 635 & 37.31 & 1,702 & 11.1 \\
\hline 1981 & 729 & 41.12 & 1,773 & 4.2 \\
\hline 1982 & 730 & 44.06 & 1,657 & -6.5 \\
\hline 1983 & 701 & 46.08 & 1,521 & -8.2 \\
\hline 1984 & 645 & 47.75 & 1,351 & -11.2 \\
\hline 1985 & 485 & 49.43 & 981 & -27.4 \\
\hline 1986 & 416 & 50.58 & 822 & -16.2 \\
\hline 1987 & 400 & 51.58 & 775 & -5.7 \\
\hline 1988 & 457 & 53.16 & 860 & 10.9 \\
\hline 1989 & 511 & 55.36 & 923 & 7.4 \\
\hline 1990 & 524 & 57.38 & 913 & -1.1 \\
\hline 1991 & 517 & 59.53 & 868 & -4.9 \\
\hline 1992 & 517 & 61.02 & 847 & -2.4 \\
\hline 1993 & 514 & 62.46 & 823 & -2.9 \\
\hline 1994 & 550 & 63.85 & 861 & 4.7 \\
\hline 1995 & 580 & 65.23 & 889 & 3.2 \\
\hline 1996 & 610 & 66.50 & 917 & 3.2 \\
\hline 1997 & 620 & 67.76 & 915 & -0.2 \\
\hline 1998 & 645 & 68.51 & 941 & 2.9 \\
\hline 1999 & 675 & 69.42 & 972 & 3.3 \\
\hline 2000 & 710 & 70.76 & 1,003 & 3.2 \\
\hline 2001 & 735 & 72.42 & 1,015 & 1.2 \\
\hline 2002 & 760 & 73.63 & 1,032 & 1.7 \\
\hline 2003 & 775 & 75.00 & 1,033 & 0.1 \\
\hline 2004 & 810 & 76.64 & 1,057 & 2.3 \\
\hline 2005 & 910 & 78.99 & 1,152 & 9.0 \\
\hline 2006 & 1,030 & 81.47 & 1,264 & 9.7 \\
\hline 2007 & 1,140 & 83.85 & 1,360 & 7.5 \\
\hline 2008 & 1,330 & 85.48 & 1,556 & 14.4 \\
\hline 2009 & 1,320 & 86.84 & 1,520 & -2.3 \\
\hline
\end{tabular}

$\overline{\text { Table continued }}$ on next page. 


\section{Appendix Table 2. Deflated USDA Farmland Values and Percent Changes for Nebraska, 1930 to $2019^{a}$ (continued)}

\begin{tabular}{|c|c|c|c|c|}
\hline Year & $\begin{array}{c}\text { USDA Average } \\
\text { Value/Acre For Nebraska }\end{array}$ & $\begin{array}{c}1^{\text {st }} \text { Quarter GDP } \\
\text { Price Deflator } \\
(2019=100)\end{array}$ & $\begin{array}{l}\text { Deflated Average } \\
\text { Value/Acre }^{\mathrm{b}}\end{array}$ & $\begin{array}{c}\text { Year-to-Year Change } \\
\text { Deflated Farmland in } \\
\text { Values }\end{array}$ \\
\hline 2010 & 1,470 & 87.32 & 1,684 & 10.8 \\
\hline 2011 & 1,840 & 88.95 & 2,069 & 22.9 \\
\hline 2012 & 2,420 & 91.43 & 2,647 & 27.9 \\
\hline 2013 & 2,800 & 92.47 & 3,028 & 14.4 \\
\hline 2014 & 3,120 & 94.08 & 3,316 & 9.5 \\
\hline 2015 & 3,050 & 95.22 & 3,203 & -3.4 \\
\hline 2016 & 2,950 & 94.37 & 3,126 & -2.4 \\
\hline 2017 & 2,900 & 96.36 & 3,009 & -3.7 \\
\hline 2018 & 2,850 & 98.24 & 2,901 & -3.6 \\
\hline $2019^{d}$ & 2,771 & 100.00 & 2,771 & -4.5 \\
\hline
\end{tabular}

Source: ${ }^{a}$ Revised from series reported in earlier reports. Refers to year ending March 1 for years prior to 1976; year ending February 1 for years 1976-1981; year ending April 1 for years 1982-1985; year ending February 1 for years 1986-1989; year ending January 1 for years 1990-1994; mid-year 1995-1997, and year ending January 1, 2000.

${ }^{\mathrm{b}}$ Computed by dividing the USDA average value per acre by the 1st Quarter GDP Price Deflator $(2019=100)$ and multiplying by 100 .

${ }^{c}$ A positive value entry in this column represents a real increase in asset value for the year (i.e., the rate of land value appreciation exceeded the general rate of inflation for the U.S. economy). Conversely, a negative value entry represents a real decrease in asset value.

d Preliminary. 
Appendix Table 3. Nominal and Deflated Agricultural Land Values by Selected Types of Land in Nebraska, 1978 to $2019^{a}$

\begin{tabular}{|c|c|c|c|c|c|c|c|c|c|}
\hline \multirow[b]{2}{*}{ Year } & \multicolumn{4}{|c|}{ Nominal Value/Acre ${ }^{\mathrm{a}}$} & \multirow{2}{*}{$\begin{array}{c}1^{\text {st }} \text { Quarter } \\
\text { GDP Price } \\
\text { Deflator } \\
(2019=100)\end{array}$} & \multicolumn{4}{|c|}{ Deflated Value/Acre $^{\mathrm{b}}$} \\
\hline & $\begin{array}{l}\text { Dryland } \\
\text { Cropland }\end{array}$ & $\begin{array}{l}\text { Center Pivot } \\
\text { Irrigated } \\
\text { Cropland }^{c}\end{array}$ & $\begin{array}{c}\text { Grazing } \\
\text { Land } \\
\text { (Nontillable) }\end{array}$ & $\begin{array}{l}\text { All-Land } \\
\text { Average }\end{array}$ & & $\begin{array}{l}\text { Dryland } \\
\text { Cropland }\end{array}$ & $\begin{array}{c}\text { Center Pivot } \\
\text { Irrigated } \\
\text { Cropland }^{\mathfrak{c}}\end{array}$ & $\begin{array}{c}\text { Grazing } \\
\text { Land } \\
\text { (Nontillable) }\end{array}$ & $\begin{array}{l}\text { All-Land } \\
\text { Average }^{\mathrm{d}}\end{array}$ \\
\hline & \multicolumn{4}{|c|}{ 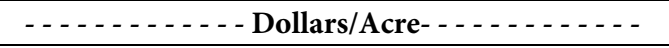 } & & \multicolumn{4}{|c|}{ 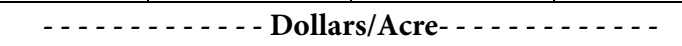 } \\
\hline 1978 & 466 & 1,015 & 151 & 489 & 31.82 & 1,465 & 3,190 & 475 & 1,537 \\
\hline 1979 & 562 & 1,201 & 185 & 584 & 34.27 & 1,640 & 3,505 & 540 & 1,704 \\
\hline 1980 & 655 & 1,384 & 207 & 677 & 37.31 & 1,756 & 3,710 & 555 & 1,815 \\
\hline 1981 & 734 & 1,470 & 228 & 729 & 41.12 & 1,785 & 3,575 & 554 & 1,773 \\
\hline 1982 & 701 & 1,410 & 225 & 701 & 44.06 & 1,591 & 3,200 & 511 & 1,591 \\
\hline 1983 & 644 & 1,222 & 204 & 621 & 46.08 & 1,398 & 2,652 & 443 & 1,348 \\
\hline 1984 & 600 & 1,143 & 183 & 574 & 47.75 & 1,257 & 2,394 & 383 & 1,202 \\
\hline 1985 & 497 & 899 & 134 & 466 & 49.43 & 1,005 & 1,819 & 271 & 943 \\
\hline 1986 & 367 & 689 & 97 & 335 & 50.58 & 726 & 1,364 & 192 & 662 \\
\hline 1987 & 353 & 626 & 82 & 302 & 51.58 & 684 & 1,214 & 159 & 585 \\
\hline 1988 & 395 & 718 & 90 & 342 & 53.16 & 743 & 1,351 & 169 & 643 \\
\hline 1989 & 474 & 910 & 122 & 428 & 55.36 & 856 & 1,644 & 220 & 773 \\
\hline 1990 & 503 & 1,003 & 144 & 470 & 57.38 & 877 & 1,748 & 251 & 819 \\
\hline 1991 & 506 & 1,060 & 157 & 490 & 59.53 & 850 & 1,781 & 264 & 823 \\
\hline 1992 & 518 & 1,089 & 163 & 506 & 61.02 & 849 & 1,785 & 267 & 829 \\
\hline 1993 & 540 & 1,140 & 169 & 528 & 62.46 & 865 & 1,825 & 271 & 845 \\
\hline 1994 & 571 & 1,206 & 181 & 563 & 63.85 & 894 & 1,889 & 283 & 882 \\
\hline 1995 & 584 & 1,254 & 189 & 581 & 65.23 & 895 & 1,922 & 290 & 891 \\
\hline 1996 & 615 & 1,342 & 186 & 608 & 66.50 & 925 & 2,018 & 280 & 914 \\
\hline 1997 & 659 & 1,465 & 200 & 657 & 67.76 & 973 & 2,162 & 295 & 970 \\
\hline 1998 & 713 & 1,614 & 221 & 716 & 68.51 & 1,041 & 2,356 & 323 & 1,045 \\
\hline 1999 & 693 & 1,568 & 216 & 697 & 69.42 & 998 & 2,259 & 311 & 1,004 \\
\hline 2000 & 695 & 1,600 & 228 & 707 & 70.76 & 982 & 2,261 & 322 & 999 \\
\hline 2001 & 699 & 1,608 & 240 & 719 & 72.42 & 965 & 2,220 & 331 & 993 \\
\hline 2002 & 733 & 1,660 & 250 & 746 & 73.63 & 995 & 2,254 & 340 & 1,013 \\
\hline 2003 & 741 & 1,679 & 250 & 756 & 75.00 & 988 & 2,239 & 333 & 1,008 \\
\hline 2004 & 808 & 1,833 & 275 & 824 & 76.64 & 1,054 & 2,392 & 359 & 1,075 \\
\hline 2005 & 908 & 2,045 & 317 & 914 & 78.99 & 1,150 & 2,589 & 401 & 1,157 \\
\hline 2006 & 1,008 & 2,197 & 353 & 1,001 & 81.47 & 1,237 & 2,697 & 433 & 1,229 \\
\hline 2007 & 1,153 & 2,509 & 402 & 1,145 & 83.85 & 1,375 & 2,992 & 479 & 1,366 \\
\hline 2008 & 1,457 & 3,157 & 451 & 1,414 & 85.48 & 1,705 & 3,693 & 528 & 1,654 \\
\hline 2009 & 1,441 & 3,304 & 449 & 1,431 & 86.84 & 1,659 & 3,805 & 517 & 1,648 \\
\hline
\end{tabular}

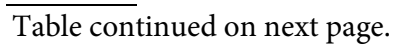


Appendix Table 3. Nominal and Deflated Agricultural Land Values by Selected Types of Land in Nebraska, 1978 to $2019^{\text {a }}$ (continued)

\begin{tabular}{|c|c|c|c|c|c|c|c|c|c|}
\hline \multirow[b]{2}{*}{ Year } & \multicolumn{4}{|c|}{ Nominal Value/Acre ${ }^{a}$} & \multirow{2}{*}{$\begin{array}{c}1^{\text {st }} \text { Quarter } \\
\text { GDP Price } \\
\text { Deflator } \\
(2019=100)\end{array}$} & \multicolumn{4}{|c|}{ Deflated Value/Acre ${ }^{\mathrm{b}}$} \\
\hline & $\begin{array}{l}\text { Dryland } \\
\text { Cropland }\end{array}$ & $\begin{array}{c}\text { Center Pivot } \\
\text { Irrigated } \\
\text { Cropland } \\
\end{array}$ & $\begin{array}{c}\text { Grazing } \\
\text { Land } \\
\text { (Nontillable) }\end{array}$ & $\begin{array}{l}\text { All-Land } \\
\text { Average }\end{array}$ & & $\begin{array}{l}\text { Dryland } \\
\text { Cropland }\end{array}$ & $\begin{array}{c}\text { Center Pivot } \\
\text { Irrigated } \\
\text { Cropland } \\
\end{array}$ & $\begin{array}{c}\text { Grazing } \\
\text { Land } \\
\text { (Nontillable) }\end{array}$ & $\begin{array}{l}\text { All-Land } \\
\text { Average }^{\mathrm{d}}\end{array}$ \\
\hline & \multicolumn{4}{|c|}{ 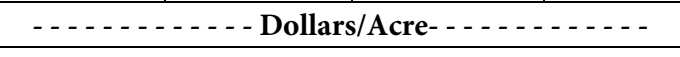 } & & \multicolumn{4}{|c|}{ 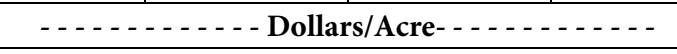 } \\
\hline 2010 & 1,530 & 3,520 & 425 & 1,503 & 87.32 & 1,752 & 4,031 & 487 & 1,721 \\
\hline 2011 & 1,850 & 4,343 & 490 & 1,833 & 88.95 & 2,080 & 4,883 & 551 & 2,061 \\
\hline 2012 & 2,585 & 5,835 & 585 & 2,425 & 91.43 & 2,827 & 6,382 & 640 & 2,652 \\
\hline 2013 & 3,365 & 7,430 & 695 & 3,045 & 92.47 & 4,034 & 8,311 & 935 & 3,585 \\
\hline 2014 & 3,730 & 7,685 & 865 & 3,315 & 94.08 & 3,965 & 8,169 & 919 & 3,524 \\
\hline 2015 & 3,390 & 7,315 & 1,005 & 3,250 & 95.22 & 3,560 & 7,682 & 1,055 & 3,413 \\
\hline 2016 & 3,470 & 6,940 & 975 & 3,115 & 94.37 & 3,677 & 7,354 & 1,033 & 3,301 \\
\hline 2017 & 3,145 & 6,295 & 895 & 2,820 & 96.36 & 3,264 & 6,533 & 929 & 2,926 \\
\hline 2018 & 3,100 & 6,130 & 835 & 2,720 & 98.24 & 3,155 & 6,240 & 850 & 2,769 \\
\hline 2019 & 3,040 & 5,970 & 795 & 2,645 & 100.00 & 3,040 & 5,970 & 795 & 2,645 \\
\hline
\end{tabular}

Source: a Annual February 1, estimates reported in the UNL Nebraska Farm Real Estate Market Surveys, 1978-2019: revised series, June 2009.

b Computed by dividing USDA average value per acre by the 1st Quarter GDP Price Deflator $(2019=100)$ and multiplying by 100.

${ }^{c}$ Pivot not included in per acre value.

${ }^{\mathrm{d}}$ Deflated all-land average based on the UNL Nebraska Farm Real Estate Market Surveys and will not correspond directly with the USDA series presented in Appendix Table 2. 
Appendix Table 4. Average Reported Value of Nebraska Farmland for Different Types of Land by Agricultural Statistics District, 1978-2019ª

\begin{tabular}{|c|c|c|c|c|c|c|c|c|c|}
\hline \multirow{2}{*}{ Year } & \multicolumn{7}{|c|}{ Agricultural Statistics District } \\
\cline { 2 - 8 } & Northwest & North & Northeast & Central & East & Southwest & South & Southeast $^{\text {State }}{ }^{\text {b }}$ \\
\hline
\end{tabular}

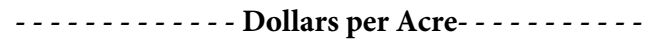

Dryland Cropland (No Irrigation Potential)

\begin{tabular}{|c|c|c|c|c|c|c|c|c|c|}
\hline 1978 & 289 & 253 & 648 & 319 & 817 & 360 & 468 & 660 & 466 \\
\hline 1979 & 317 & 319 & 813 & 397 & 1,061 & 387 & 541 & 808 & 562 \\
\hline 1980 & 347 & 340 & 920 & 471 & 1,296 & 454 & 626 & 971 & 655 \\
\hline 1981 & 419 & 346 & 1,009 & 519 & 1,409 & 546 & 754 & 1,060 & 734 \\
\hline 1982 & 411 & 335 & 966 & 502 & 1,325 & 522 & 752 & 988 & 701 \\
\hline 1983 & 387 & 321 & 864 & 450 & 1,204 & 469 & 664 & 939 & 644 \\
\hline 1984 & 379 & 300 & 779 & 416 & 1,128 & 444 & 653 & 840 & 600 \\
\hline 1985 & 325 & 237 & 643 & 340 & 905 & 365 & 474 & 612 & 497 \\
\hline 1986 & 259 & 198 & 499 & 263 & 669 & 308 & 412 & 423 & 367 \\
\hline 1987 & 242 & 190 & 520 & 246 & 626 & 288 & 377 & 416 & 353 \\
\hline 1988 & 267 & 202 & 576 & 301 & 692 & 294 & 411 & 513 & 395 \\
\hline 1989 & 305 & 250 & 688 & 370 & 824 & 371 & 491 & 621 & 474 \\
\hline 1990 & 309 & 279 & 728 & 407 & 877 & 409 & 491 & 662 & 503 \\
\hline 1991 & 316 & 279 & 735 & 463 & 885 & 380 & 508 & 655 & 506 \\
\hline 1992 & 340 & 295 & 700 & 418 & 955 & 386 & 513 & 673 & 518 \\
\hline 1993 & 337 & 288 & 766 & 486 & 1,000 & 373 & 573 & 701 & 540 \\
\hline 1994 & 345 & 314 & 797 & 504 & 1,090 & 390 & 620 & 741 & 571 \\
\hline 1995 & 335 & 320 & 803 & 519 & 1,144 & 403 & 637 & 764 & 584 \\
\hline 1996 & 358 & 338 & 823 & 535 & 1,244 & 419 & 658 & 799 & 615 \\
\hline 1997 & 381 & 363 & 909 & 588 & 1,336 & 432 & 701 & 852 & 659 \\
\hline 1998 & 385 & 390 & 982 & 631 & 1,477 & 457 & 753 & 956 & 713 \\
\hline 1999 & 346 & 367 & 968 & 635 & 1,462 & 428 & 740 & 953 & 693 \\
\hline 2000 & 331 & 400 & 970 & 648 & 1,464 & 434 & 708 & 958 & 695 \\
\hline 2001 & 319 & 403 & 996 & 645 & 1,493 & 433 & 725 & 954 & 699 \\
\hline 2002 & 325 & 407 & 1,095 & 680 & 1,523 & 460 & 743 & 1,024 & 733 \\
\hline 2003 & 319 & 360 & 1,107 & 710 & 1,585 & 453 & 748 & 1,059 & 741 \\
\hline 2004 & 328 & 416 & 1,231 & 758 & 1,717 & 473 & 800 & 1,190 & 808 \\
\hline 2005 & 330 & 447 & 1,382 & 847 & 2,024 & 495 & 864 & 1,396 & 908 \\
\hline 2006 & 348 & 483 & 1,641 & 933 & 2,276 & 519 & 875 & 1,563 & 1,008 \\
\hline 2007 & 383 & 558 & 1,917 & 1,056 & 2,608 & 559 & 932 & 1,840 & 1,153 \\
\hline 2008 & 460 & 707 & 2,482 & 1,347 & 3,203 & 693 & 1,241 & 2,367 & 1,457 \\
\hline 2009 & 464 & 692 & 2,498 & 1,300 & 3,101 & 696 & 1,318 & 2,297 & 1,441 \\
\hline
\end{tabular}

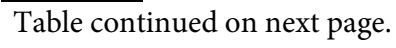


Appendix Table 4. Average Reported Value of Nebraska Farmland for Different Types of Land by Agricultural Statistics District, 1978-2019 ${ }^{a}$ (continued)

\begin{tabular}{|c|c|c|c|c|c|c|c|c|c|}
\hline \multirow{2}{*}{ Year } & \multicolumn{9}{|c|}{ Agricultural Statistics District } \\
\cline { 2 - 8 } & Northwest & North & Northeast & Central & East & Southwest & South & Southeast & State \\
\hline
\end{tabular}

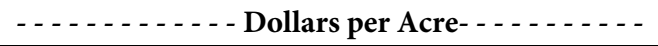

Dryland Cropland (No Irrigation Potential)

$\begin{array}{lrrrrrrrrr}\mathbf{2 0 1 0} & 475 & 715 & 2,740 & 1,365 & 3,330 & 735 & 1,380 & 2,410 & 1,530 \\ \mathbf{2 0 1 1} & 545 & 800 & 3,450 & 1,605 & 3,995 & 875 & 1,738 & 2,925 & 1,850 \\ \mathbf{2 0 1 2} & 660 & 1,050 & 4,740 & 2,170 & 5,385 & 1,250 & 2,250 & 3,800 & 2,485 \\ \mathbf{2 0 1 3} & 700 & 1,155 & 5,995 & 2,625 & 6,730 & 1,530 & 3,240 & 4,925 & 3,010 \\ \mathbf{2 0 1 4} & 845 & 1,720 & 6,430 & 3,490 & 6,575 & 1,965 & 3,490 & 5,425 & 3,730 \\ \mathbf{2 0 1 5} & 730 & 1,580 & 5,645 & 3,115 & 5,980 & 1,855 & 3,340 & 5,060 & 3,390 \\ \mathbf{2 0 1 6} & 745 & 1,650 & 5,760 & 3,235 & 6,360 & 1,955 & 3,575 & 4,845 \\ \mathbf{2 0 1 7} & 715 & 1,560 & 5,410 & 2,785 & 5,790 & 1,710 & 3,045 & 4,285 & 3,470 \\ \mathbf{2 0 1 8} & 670 & 1,515 & 5,530 & 2,720 & 5,675 & 1,585 & 2,965 & 4,205 & 3,100 \\ \mathbf{2 0 1 9} & 645 & 1,495 & 5,300 & 2,755 & 5,675 & 1,445 & 2,880 & 4,130 & 3,040\end{array}$

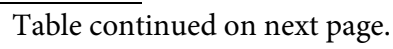


Appendix Table 4. Average Reported Value of Nebraska Farmland for Different Types of Land by Agricultural Statistics District, 1978-2019 ${ }^{a}$ (continued)

\begin{tabular}{|c|c|c|c|c|c|c|c|c|c|}
\hline \multirow{2}{*}{ Year } & \multicolumn{7}{|c|}{ Agricultural Statistics District } \\
\cline { 2 - 9 } & Northwest & North & Northeast & Central & East & Southwest & South & Southeast & State ${ }^{\text {b }}$ \\
\hline
\end{tabular}

. . . . . . . . . . - Dollars per Acre- . . . . . . . . . .

Dryland Cropland (Irrigation Potential)

\begin{tabular}{|c|c|c|c|c|c|c|c|c|c|}
\hline 1978 & 409 & 387 & 741 & 590 & 128 & 471 & 873 & 953 & 757 \\
\hline 1979 & 449 & 514 & 930 & 708 & 1,411 & 520 & 1,102 & 1,152 & 926 \\
\hline 1980 & 533 & 565 & 1,132 & 767 & 1,733 & 628 & 1,282 & 1,352 & 1,147 \\
\hline 1981 & 680 & 533 & 1,225 & 880 & 1,785 & 733 & 1,432 & 1,402 & 1,223 \\
\hline 1982 & 658 & 535 & 1,097 & 833 & 1,665 & 685 & 1,411 & 1,268 & 1,132 \\
\hline 1983 & 563 & 462 & 975 & 680 & 1,462 & 654 & 1,175 & 1,160 & 1,002 \\
\hline 1984 & 507 & 441 & 911 & 638 & 1,349 & 631 & 1,050 & 1,069 & 929 \\
\hline 1985 & 425 & 340 & 746 & 486 & 1,013 & 504 & 705 & 723 & 708 \\
\hline 1986 & 312 & 300 & 598 & 367 & 746 & 377 & 573 & 545 & 542 \\
\hline 1987 & 285 & 250 & 567 & 325 & 707 & 328 & 503 & 508 & 504 \\
\hline 1988 & 310 & 266 & 646 & 380 & 801 & 339 & 576 & 623 & 574 \\
\hline 1989 & 376 & 339 & 773 & 483 & 980 & 433 & 684 & 772 & 702 \\
\hline 1990 & 371 & 367 & 840 & 539 & 1,056 & 473 & 706 & 816 & 752 \\
\hline 1991 & 396 & 360 & 817 & 604 & 1,083 & 478 & 756 & 777 & 754 \\
\hline 1992 & 411 & 381 & 823 & 658 & 1,124 & 476 & 792 & 835 & 781 \\
\hline 1993 & 419 & 400 & 884 & 678 & 1,195 & 445 & 883 & 888 & 825 \\
\hline 1994 & 430 & 436 & 962 & 739 & 1,338 & 482 & 923 & 936 & 899 \\
\hline 1995 & 429 & 424 & 1,002 & 781 & 1,397 & 493 & 941 & 979 & 932 \\
\hline 1996 & 441 & 444 & 1,040 & 845 & 1,525 & 508 & 1,008 & 1,046 & 992 \\
\hline 1997 & 458 & 475 & 1,103 & 917 & 1,643 & 543 & 1,114 & 1,130 & 1,064 \\
\hline 1998 & 482 & 510 & 1,219 & 986 & 1,810 & 578 & 1,216 & 1,250 & 1,167 \\
\hline 1999 & 436 & 480 & 1,216 & 956 & 1,792 & 538 & 1,173 & 1,172 & 1,137 \\
\hline 2000 & 418 & 492 & 1,220 & 951 & 1,800 & 546 & 1,112 & 1,187 & 1,140 \\
\hline 2001 & 409 & 500 & 1,256 & 981 & 1,807 & 572 & 1,126 & 1,234 & 1,161 \\
\hline 2002 & 418 & 514 & 1,355 & 1,020 & 1,814 & 581 & 1,145 & 1,318 & 1,205 \\
\hline 2003 & 396 & 480 & 1,410 & 1,095 & 1,930 & 558 & 1,118 & 1,290 & 1,240 \\
\hline 2004 & 445 & 534 & 1,554 & 1,137 & 2,093 & 586 & 1,217 & 1,469 & 1,360 \\
\hline 2005 & 450 & 579 & 1,696 & 1,286 & 2,395 & 606 & 1,330 & 1,642 & 1,513 \\
\hline 2006 & 455 & 650 & 1,931 & 1,450 & 2,642 & 623 & 1,229 & 1,854 & 1,677 \\
\hline 2007 & 490 & 808 & 2,407 & 1,564 & 2,900 & 702 & 1,126 & 2,150 & 1,931 \\
\hline 2008 & 505 & 1,035 & 3,145 & 1,894 & 3,691 & 716 & 1,301 & 2,700 & 2,440 \\
\hline 2009 & 500 & 1,008 & 3,000 & 1,818 & 3,558 & 750 & 1,415 & 2,982 & 2,411 \\
\hline
\end{tabular}

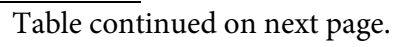


Appendix Table 4. Average Reported Value of Nebraska Farmland for Different Types of Land by Agricultural Statistics District, $1978-2019^{a}$ (continued)

\begin{tabular}{|c|c|c|c|c|c|c|c|c|c|}
\hline \multirow{2}{*}{ Year } & \multicolumn{9}{|c|}{ Agricultural Statistics District } \\
\hline & Northwest & North & Northeast & Central & East & Southwest & South & Southeast & State $^{b}$ \\
\hline
\end{tabular}

Dryland Cropland (Irrigation Potential)

$\begin{array}{llllllrrrr}\mathbf{2 0 1 0} & 515 & 1,095 & 3,280 & 1,910 & 3,995 & 775 & 1,535 & 2,995 & 2,611 \\ \mathbf{2 0 1 1} & 550 & 1,200 & 4,200 & 2,355 & 4,765 & 905 & 2,090 & 3,640 & 3,192 \\ \mathbf{2 0 1 2} & 680 & 1,625 & 5,800 & 3,360 & 6,390 & 1,275 & 2,945 & 5,035 & 4,355 \\ \mathbf{2 0 1 3} & 730 & 1,920 & 7,050 & 3,945 & 7,400 & 1,655 & 4,175 & 6,590 & 5,270 \\ \mathbf{2 0 1 4} & 935 & 2,390 & 7,215 & 4,910 & 7,545 & 2,035 & 5,090 & 7,100 & 5,240 \\ \mathbf{2 0 1 5} & 870 & 2,290 & 7,065 & 4,095 & 7,310 & 1,950 & 4,510 & 6,940 & 5,030 \\ \mathbf{2 0 1 6} & 790 & 2,150 & 6,715 & 3,850 & 7,165 & 1,815 & 4,315 & 6,450 & 4,785 \\ \mathbf{2 0 1 7} & 765 & 2,110 & 5,980 & 3,220 & 6,455 & 1,720 & 3,750 & 5,390 & 4,225 \\ \mathbf{2 0 1 8} & 730 & 1,985 & 5,800 & 3,095 & 6,280 & 1,635 & 3,620 & 5,345 & 4,115 \\ \mathbf{2 0 1 9} & 680 & 1,915 & 5,640 & 3,055 & 6,145 & 1,585 & 3,450 & 5,265 & 4,010\end{array}$

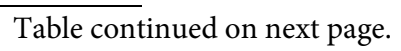


Appendix Table 4. Average Reported Value of Nebraska Farmland for Different Types of Land by Agricultural Statistics District, 1978-2019 ${ }^{a}$ (continued)

\begin{tabular}{|c|c|c|c|c|c|c|c|c|c|}
\hline \multirow{2}{*}{ Year } & \multicolumn{10}{|c|}{ Agricultural Statistics District } \\
\cline { 2 - 9 } & Northwest & North & Northeast & Central & East & Southwest & South & Southeast & State ${ }^{\text {b }}$ \\
\hline
\end{tabular}

- . . . . . . . . . - Dollars per Acre- . . . . . . . . . .

Grazing Land (Tillable)

\begin{tabular}{|c|c|c|c|c|c|c|c|c|c|}
\hline 1978 & 177 & 191 & 433 & 299 & 549 & 215 & 465 & 433 & 244 \\
\hline 1979 & 186 & 229 & 521 & 347 & 701 & 259 & 479 & 574 & 285 \\
\hline 1980 & 200 & 261 & 583 & 395 & 760 & 307 & 621 & 643 & 324 \\
\hline 1981 & 251 & 257 & 622 & 435 & 881 & 332 & 697 & 636 & 353 \\
\hline 1982 & 248 & 248 & 605 & 422 & 824 & 317 & 710 & 654 & 344 \\
\hline 1983 & 198 & 234 & 571 & 405 & 739 & 315 & 555 & 589 & 311 \\
\hline 1984 & 187 & 233 & 500 & 325 & 661 & 285 & 519 & 521 & 285 \\
\hline 1985 & 146 & 180 & 392 & 259 & 510 & 205 & 339 & 357 & 215 \\
\hline 1986 & 101 & 135 & 275 & 166 & 366 & 146 & 250 & 241 & 152 \\
\hline 1987 & 77 & 99 & 267 & 135 & 336 & 115 & 187 & 236 & 123 \\
\hline 1988 & 80 & 107 & 294 & 168 & 361 & 100 & 208 & 292 & 132 \\
\hline 1989 & 104 & 150 & 362 & 217 & 418 & 130 & 253 & 341 & 170 \\
\hline 1990 & 102 & 185 & 381 & 270 & 459 & 153 & 296 & 360 & 194 \\
\hline 1991 & 107 & 200 & 394 & 308 & 495 & 168 & 338 & 366 & 209 \\
\hline 1992 & 113 & 213 & 395 & 339 & 500 & 169 & 348 & 395 & 220 \\
\hline 1993 & 121 & 195 & 427 & 359 & 524 & 171 & 371 & 418 & 223 \\
\hline 1994 & 128 & 215 & 440 & 380 & 573 & 192 & 407 & 460 & 242 \\
\hline 1995 & 128 & 223 & 456 & 400 & 611 & 193 & 414 & 471 & 249 \\
\hline 1996 & 125 & 225 & 473 & 406 & 617 & 196 & 413 & 483 & 251 \\
\hline 1997 & 135 & 250 & 512 & 440 & 686 & 200 & 433 & 519 & 272 \\
\hline 1998 & 153 & 265 & 550 & 461 & 741 & 227 & 467 & 575 & 295 \\
\hline 1999 & 165 & 270 & 569 & 456 & 735 & 234 & 470 & 575 & 301 \\
\hline 2000 & 173 & 275 & 581 & 471 & 731 & 256 & 464 & 588 & 310 \\
\hline 2001 & 171 & 288 & 670 & 505 & 750 & 291 & 524 & 578 & 329 \\
\hline 2002 & 182 & 299 & 706 & 523 & 796 & 325 & 537 & 629 & 348 \\
\hline 2003 & 180 & 280 & 750 & 562 & 801 & 290 & 534 & 640 & 342 \\
\hline 2004 & 212 & 307 & 794 & 611 & 926 & 305 & 558 & 716 & 377 \\
\hline 2005 & 225 & 330 & 919 & 658 & 1,075 & 316 & 640 & 830 & 412 \\
\hline 2006 & 251 & 383 & 1,067 & 740 & 1,224 & 349 & 651 & 962 & 466 \\
\hline 2007 & 282 & 475 & 1,343 & 848 & 1,493 & 387 & 684 & 1,083 & 574 \\
\hline 2008 & 316 & 567 & 1,578 & 1,018 & 1,927 & 417 & 887 & 1,380 & 651 \\
\hline 2009 & 330 & 565 & 1,525 & 996 & 1,876 & 416 & 936 & 1,358 & 649 \\
\hline
\end{tabular}

Table continued on next page. 
Appendix Table 4. Average Reported Value of Nebraska Farmland for Different Types of Land by Agricultural Statistics District, 1978-2019 ${ }^{a}$ (continued)

\begin{tabular}{|c|c|c|c|c|c|c|c|c|c|}
\hline \multirow{2}{*}{ Year } & \multicolumn{8}{|c|}{ Agricultural Statistics District } \\
\cline { 2 - 8 } & Northwest & North & Northeast & Central & East & Southwest & South & Southeast & State ${ }^{\mathrm{b}}$ \\
\hline
\end{tabular}

\section{Grazing Land (Tillable)}

$\begin{array}{rrrrrrrrrr}\mathbf{2 0 1 0} & 320 & 595 & 1,640 & 990 & 1,965 & 435 & 960 & 1,430 & 669 \\ \mathbf{2 0 1 1} & 340 & 740 & 2,090 & 1,145 & 2,365 & 490 & 1,100 & 1,795 & 797 \\ \mathbf{2 0 1 2} & 410 & 880 & 2,690 & 1,670 & 2,965 & 590 & 1,500 & 2,400 & 1,010 \\ \mathbf{2 0 1 3} & 425 & 1,050 & 3,575 & 2,075 & 3,390 & 665 & 2,075 & 3,195 & 1,230 \\ \mathbf{2 0 1 4} & 550 & 1,150 & 4,075 & 2,300 & 3,620 & 890 & 2,430 & 3,285 & 1,390 \\ \mathbf{2 0 1 5} & 535 & 1,395 & 3,695 & 2,615 & 4,205 & 1,135 & 2,350 & 3,035 & 1,515 \\ \mathbf{2 0 1 6} & 565 & 1,325 & 3,955 & 2,460 & 4,370 & 1,070 & 2,240 & 3,200 & 1,495 \\ \mathbf{2 0 1 7} & 530 & 1,170 & 3,665 & 2,155 & 3,765 & 975 & 2,040 & 2,780 & 1,335 \\ \mathbf{2 0 1 8} & 510 & 1,075 & 3,330 & 1,935 & 3,335 & 950 & 1,950 & 2,845 & 1,250 \\ \mathbf{2 0 1 9} & 500 & 1,040 & 3,125 & 1,750 & 3,075 & 880 & 1,875 & 2,760 & 1,185\end{array}$

Table continued on next page. 
Appendix Table 4. Average Reported Value of Nebraska Farmland for Different Types of Land by Agricultural Statistics District, $1978-2019^{a}$ (continued)

\begin{tabular}{|c|c|c|c|c|c|c|c|c|c|}
\hline \multirow{2}{*}{ Year } & \multicolumn{9}{|c|}{ Agricultural Statistics District } \\
\cline { 2 - 8 } & Northwest & North & Northeast & Central & East & Southwest & South & Southeast & State \\
\hline
\end{tabular}

\section{Grazing Land (Nontillable)}

\begin{tabular}{|c|c|c|c|c|c|c|c|c|c|}
\hline 1978 & 115 & 126 & 308 & 216 & 384 & 119 & 268 & 315 & 153 \\
\hline 1979 & 134 & 156 & 340 & 267 & 486 & 148 & 309 & 417 & 186 \\
\hline 1980 & 143 & 169 & 394 & 304 & 549 & 190 & 346 & 473 & 207 \\
\hline 1981 & 164 & 182 & 418 & 339 & 620 & 217 & 398 & 474 & 228 \\
\hline 1982 & 168 & 183 & 412 & 329 & 584 & 195 & 418 & 472 & 225 \\
\hline 1983 & 151 & 169 & 375 & 283 & 511 & 181 & 339 & 460 & 204 \\
\hline 1984 & 134 & 152 & 350 & 248 & 455 & 168 & 328 & 384 & 183 \\
\hline 1985 & 94 & 115 & 258 & 192 & 341 & 118 & 236 & 243 & 134 \\
\hline 1986 & 71 & 85 & 179 & 131 & 262 & 84 & 158 & 178 & 97 \\
\hline 1987 & 60 & 71 & 166 & 106 & 238 & 68 & 120 & 173 & 82 \\
\hline 1988 & 58 & 76 & 189 & 128 & 270 & 75 & 152 & 220 & 90 \\
\hline 1989 & 71 & 109 & 242 & 183 & 310 & 101 & 209 & 266 & 122 \\
\hline 1990 & 83 & 134 & 272 & 225 & 340 & 113 & 233 & 298 & 144 \\
\hline 1991 & 86 & 148 & 284 & 252 & 357 & 125 & 254 & 314 & 157 \\
\hline 1992 & 90 & 155 & 302 & 267 & 373 & 126 & 261 & 316 & 163 \\
\hline 1993 & 93 & 157 & 322 & 278 & 382 & 136 & 290 & 330 & 169 \\
\hline 1994 & 98 & 167 & 325 & 302 & 388 & 153 & 307 & 354 & 181 \\
\hline 1995 & 106 & 175 & 337 & 308 & 421 & 163 & 308 & 357 & 189 \\
\hline 1996 & 103 & 173 & 347 & 299 & 428 & 155 & 296 & 367 & 186 \\
\hline 1997 & 115 & 183 & 366 & 327 & 468 & 163 & 318 & 412 & 200 \\
\hline 1998 & 128 & 199 & 395 & 366 & 516 & 189 & 337 & 473 & 221 \\
\hline 1999 & 127 & 192 & 411 & 350 & 507 & 187 & 327 & 476 & 216 \\
\hline 2000 & 137 & 206 & 432 & 365 & 510 & 193 & 333 & 478 & 228 \\
\hline 2001 & 142 & 220 & 475 & 386 & 532 & 200 & 353 & 479 & 240 \\
\hline 2002 & 151 & 218 & 515 & 419 & 584 & 213 & 378 & 499 & 250 \\
\hline 2003 & 149 & 210 & 559 & 446 & 590 & 219 & 389 & 490 & 250 \\
\hline 2004 & 163 & 230 & 619 & 494 & 655 & 240 & 422 & 550 & 275 \\
\hline 2005 & 191 & 269 & 706 & 543 & 784 & 273 & 482 & 629 & 317 \\
\hline 2006 & 215 & 307 & 800 & 588 & 907 & 298 & 497 & 688 & 353 \\
\hline 2007 & 250 & 358 & 900 & 668 & 1,033 & 310 & 553 & 749 & 402 \\
\hline 2008 & 287 & 386 & 975 & 781 & 1,219 & 344 & 658 & 883 & 451 \\
\hline 2009 & 281 & 378 & 1,000 & 733 & 1,202 & 370 & 707 & 945 & 449 \\
\hline
\end{tabular}

\footnotetext{
Table continued on next page.
} 
Appendix Table 4. Average Reported Value of Nebraska Farmland for Different Types of Land by Agricultural Statistics District, $1978-2019^{a}$ (continued)

\begin{tabular}{|c|c|c|c|c|c|c|c|c|c|}
\hline \multirow{2}{*}{ Year } & \multicolumn{9}{|c|}{ Agricultural Statistics District } \\
\hline & Northwest & North & Northeast & Central & East & Southwest & South & Southeast & State $^{b}$ \\
\hline
\end{tabular}

Grazing Land (Nontillable)

\begin{tabular}{|c|c|c|c|c|c|c|c|c|c|}
\hline 2010 & 260 & 340 & 1,060 & 685 & 1,265 & 350 & 710 & 975 & 425 \\
\hline 2011 & 280 & 390 & 1,210 & 810 & 1,530 & 415 & 805 & 1,195 & 490 \\
\hline 2012 & 330 & 450 & 1,460 & 1,005 & 1,975 & 475 & 1,060 & 1,485 & 585 \\
\hline 2013 & 370 & 500 & 1,850 & 1,300 & 2,225 & 570 & 1,375 & 1,875 & 695 \\
\hline 2014 & 405 & 625 & 2,490 & 1,670 & 2,500 & 805 & 1,775 & 2,170 & 865 \\
\hline 2015 & 490 & 745 & 2,580 & 2,030 & 3,010 & 945 & 1,815 & 2,275 & 1,005 \\
\hline 2016 & 480 & 740 & 2,475 & 1,925 & 2,795 & 915 & 1,690 & 2,205 & 975 \\
\hline 2017 & 465 & 705 & 2,230 & 1,685 & 2,495 & 820 & 1,500 & 2,005 & 895 \\
\hline 2018 & 435 & 640 & 2,135 & 1,545 & 2,345 & 785 & 1,460 & 2,045 & 835 \\
\hline 2019 & 410 & 625 & 1,995 & 1,405 & 2,255 & 735 & 1,335 & 1,970 & 795 \\
\hline
\end{tabular}

Table continued on next page. 
Appendix Table 4. Average Reported Value of Nebraska Farmland for Different Types of Land by Agricultural Statistics District, $1978-2019^{a}$ (continued)

\begin{tabular}{|c|c|c|c|c|c|c|c|c|c|}
\hline \multirow{2}{*}{ Year } & \multicolumn{9}{|c|}{ Agricultural Statistics District } \\
\cline { 2 - 8 } & Northwest & North & Northeast & Central & East & Southwest & South & Southeast & State \\
\hline
\end{tabular}

Hayland

\begin{tabular}{|c|c|c|c|c|c|c|c|c|c|}
\hline 1978 & 232 & 266 & 370 & 372 & 477 & 231 & 298 & 371 & 306 \\
\hline 1979 & 287 & 308 & 436 & 397 & 593 & 281 & 545 & 509 & 367 \\
\hline 1980 & 301 & 338 & 506 & 441 & 699 & 349 & 402 & 554 & 405 \\
\hline 1981 & 323 & 331 & 558 & 482 & 738 & 368 & 417 & 532 & 419 \\
\hline 1982 & 328 & 334 & 544 & 472 & 714 & 344 & 445 & 557 & 417 \\
\hline 1983 & 290 & 286 & 509 & 408 & 658 & 344 & 375 & 496 & 371 \\
\hline 1984 & 283 & 247 & 497 & 295 & 568 & 329 & 369 & 463 & 329 \\
\hline 1985 & 261 & 206 & 332 & 273 & 470 & 250 & 258 & 311 & 265 \\
\hline 1986 & 190 & 154 & 233 & 230 & 335 & 182 & 190 & 219 & 196 \\
\hline 1987 & 160 & 119 & 188 & 195 & 271 & 148 & 175 & 201 & 160 \\
\hline 1988 & 144 & 130 & 238 & 230 & 317 & 178 & 202 & 245 & 181 \\
\hline 1989 & 194 & 183 & 295 & 275 & 382 & 220 & 268 & 291 & 233 \\
\hline 1990 & 217 & 218 & 326 & 328 & 405 & 245 & 278 & 328 & 266 \\
\hline 1991 & 225 & 240 & 330 & 350 & 434 & 252 & 286 & 361 & 284 \\
\hline 1992 & 248 & 247 & 325 & 365 & 452 & 250 & 329 & 341 & 293 \\
\hline 1993 & 242 & 265 & 365 & 366 & 473 & 251 & 360 & 358 & 308 \\
\hline 1994 & 251 & 296 & 392 & 400 & 511 & 278 & 386 & 370 & 335 \\
\hline 1995 & 260 & 300 & 418 & 408 & 528 & 277 & 397 & 385 & 344 \\
\hline 1996 & 270 & 300 & 429 & 403 & 524 & 289 & 396 & 402 & 347 \\
\hline 1997 & 295 & 325 & 459 & 438 & 575 & 300 & 403 & 435 & 375 \\
\hline 1998 & 315 & 345 & 517 & 472 & 640 & 336 & 437 & 497 & 408 \\
\hline 1999 & 318 & 325 & 507 & 457 & 625 & 330 & 412 & 502 & 395 \\
\hline 2000 & 313 & 358 & 539 & 444 & 618 & 350 & 398 & 463 & 409 \\
\hline 2001 & 306 & 381 & 563 & 458 & 677 & 364 & 450 & 502 & 430 \\
\hline 2002 & 313 & 388 & 611 & 502 & 694 & 373 & 483 & 529 & 449 \\
\hline 2003 & 319 & 380 & 660 & 557 & 765 & 375 & 508 & 575 & 468 \\
\hline 2004 & 339 & 433 & 715 & 577 & 815 & 413 & 513 & 611 & 509 \\
\hline 2005 & 383 & 438 & 780 & 600 & 928 & 416 & 600 & 669 & 541 \\
\hline 2006 & 430 & 481 & 871 & 679 & 1,071 & 449 & 633 & 760 & 604 \\
\hline 2007 & 500 & 568 & 1,005 & 791 & 1,255 & 530 & 717 & 875 & 705 \\
\hline 2008 & 570 & 688 & 1,220 & 998 & 1,525 & 660 & 859 & 1,006 & 853 \\
\hline 2009 & 550 & 660 & 1,250 & 904 & 1,440 & 700 & 870 & 991 & 827 \\
\hline
\end{tabular}

Table continued on next page. 
Appendix Table 4. Average Reported Value of Nebraska Farmland for Different Types of Land by Agricultural Statistics District, 1978-2019 ${ }^{a}$ (continued)

\begin{tabular}{|c|c|c|c|c|c|c|c|c|c|}
\hline \multirow{2}{*}{ Year } & \multicolumn{9}{|c|}{ Agricultural Statistics District } \\
\hline & Northwest & North & Northeast & Central & East & Southwest & South & Southeast & State $^{b}$ \\
\hline
\end{tabular}

\section{Hayland}

$\begin{array}{lrrrrrrrrr}\mathbf{2 0 1 0} & 525 & 625 & 1,275 & 880 & 1,465 & 660 & 880 & 1,015 \\ \mathbf{2 0 1 1} & 550 & 785 & 1,485 & 1,100 & 1,840 & 700 & 1,085 & 1,250 & 810 \\ \mathbf{2 0 1 2} & 620 & 950 & 1,985 & 1,425 & 2,500 & 925 & 1,450 & 1,665 & 1,245 \\ \mathbf{2 0 1 3} & 780 & 1,150 & 2,625 & 1,850 & 3,325 & 1,160 & 1,800 & 2,065 \\ \mathbf{2 0 1 4} & 1,025 & 1,660 & 2,915 & 2,350 & 3,280 & 1,545 & 2,350 & 2,515 & 1,585 \\ \mathbf{2 0 1 5} & 1,115 & 1,905 & 3,630 & 2,890 & 4,080 & 1,965 & 2,955 & 3,100 & 2,355 \\ \mathbf{2 0 1 6} & 890 & 1,460 & 3,430 & 2,585 & 3,200 & 1,700 & 2,340 & 2,780 & 1,965 \\ \mathbf{2 0 1 7} & 795 & 1,370 & 3,295 & 2,170 & 3,090 & 1,485 & 2,160 & 2,680 \\ \mathbf{2 0 1 8} & 765 & 1,265 & 3,155 & 1,980 & 2,990 & 1,365 & 2,060 & 2,615 & 1,815 \\ \mathbf{2 0 1 9} & 710 & 1,140 & 3,020 & 1,885 & 3,040 & 1,255 & 1,990 & 2,645 & 1,710\end{array}$

Table continued on next page. 
Appendix Table 4. Average Reported Value of Nebraska Farmland for Different Types of Land by Agricultural Statistics District, $1978-2019^{a}$ (continued)

\begin{tabular}{|c|c|c|c|c|c|c|c|c|c|}
\hline \multirow{2}{*}{ Year } & \multicolumn{7}{|c|}{ Agricultural Statistics District } \\
\cline { 2 - 9 } & Northwest & North & Northeast & Central & East & Southwest & South & Southeast & State ${ }^{\text {b }}$ \\
\hline
\end{tabular}

- . . . . . . . . - Dollars per Acre- . . . . . . . . -

\section{Gravity Irrigated Cropland}

\begin{tabular}{|c|c|c|c|c|c|c|c|c|c|}
\hline 1978 & 1,246 & 796 & 1,030 & 1,545 & 1,624 & 1,134 & 1,412 & 1,404 & 1,435 \\
\hline 1979 & 1,300 & 964 & 1,289 & 1,705 & 1,910 & 1,197 & 1,746 & 1,772 & 1,668 \\
\hline 1980 & 1,369 & 1,020 & 1,547 & 1,976 & 2,317 & 1,329 & 2,046 & 2,026 & 1,940 \\
\hline 1981 & 1,555 & 1,054 & 1,781 & 2,088 & 2,403 & 1,493 & 2,230 & 2,026 & 2,063 \\
\hline 1982 & 1,580 & 1,033 & 1,771 & 2,053 & 2,269 & 1,598 & 2,254 & 1,924 & 2,023 \\
\hline 1983 & 1,361 & 1,000 & 1,430 & 1,798 & 1,969 & 1,412 & 1,872 & 1,854 & 1,763 \\
\hline 1984 & 1,269 & 1,020 & 1,429 & 1,613 & 1,838 & 1,250 & 1,762 & 1,639 & 1,623 \\
\hline 1985 & 1,042 & 817 & 1,102 & 1,304 & 1,329 & 1,010 & 1,283 & 1,171 & 1,229 \\
\hline 1986 & 754 & 612 & 900 & 940 & 975 & 867 & 963 & 957 & 925 \\
\hline 1987 & 650 & 567 & 775 & 802 & 959 & 718 & 863 & 843 & 831 \\
\hline 1988 & 668 & 691 & 862 & 948 & 1,151 & 740 & 994 & 956 & 956 \\
\hline 1989 & 815 & 900 & 1,100 & 1,210 & 1,462 & 841 & 1,232 & 1,170 & 1,194 \\
\hline 1990 & 841 & 900 & 1,186 & 1,413 & 1,513 & 895 & 1,390 & 1285 & 1,304 \\
\hline 1991 & 834 & 917 & 1,250 & 1,518 & 1,622 & 975 & 1,480 & 1,306 & 1,381 \\
\hline 1992 & 889 & 1,035 & 1,221 & 1,563 & 1,653 & 1,021 & 1,583 & 1,413 & 1,439 \\
\hline 1993 & 857 & 1,058 & 1,246 & 1,609 & 1,730 & 1,018 & 1,643 & 1,479 & 1,484 \\
\hline 1994 & 875 & 1,070 & 1,250 & 1,666 & 1,842 & 1,093 & 1,728 & 1,568 & 1,558 \\
\hline 1995 & 857 & 1,065 & 1,260 & 1,671 & 1,887 & 1,090 & 1,731 & 1,606 & 1,573 \\
\hline 1996 & 870 & 1,070 & 1,361 & 1,738 & 1,989 & 1,138 & 1,800 & 1,697 & 1,646 \\
\hline 1997 & 890 & 1,115 & 1,466 & 1,858 & 2,160 & 1,167 & 1,943 & 1,853 & 1,768 \\
\hline 1998 & 925 & 1,150 & 1,575 & 1,972 & 2,340 & 1,200 & 2,042 & 1,936 & 1,876 \\
\hline 1999 & 894 & 1,050 & 1,575 & 1,861 & 2,247 & 1,198 & 1,945 & 1,813 & 1,792 \\
\hline 2000 & 907 & 1,025 & 1,696 & 1,754 & 2,279 & 1,325 & 1,856 & 1,831 & 1,777 \\
\hline 2001 & 900 & 1,033 & 1,715 & 1,729 & 2,273 & 1,279 & 1,810 & 1,843 & 1,760 \\
\hline 2002 & 914 & 1,080 & 1,759 & 1,825 & 2,298 & 1,350 & 1,827 & 1,928 & 1,809 \\
\hline 2003 & 890 & 1,075 & 1,760 & 1,835 & 2,401 & 1,213 & 1,863 & 1,899 & 1,828 \\
\hline 2004 & 925 & 1,125 & 1,867 & 1,961 & 2,531 & 1,297 & 1,969 & 2,087 & 1,944 \\
\hline 2005 & 975 & 1,183 & 1,980 & 2,153 & 2,691 & 1,365 & 2,021 & 2,173 & 2,061 \\
\hline 2006 & 1,036 & 1,199 & 2,310 & 2,295 & 2,953 & 1,340 & 1,925 & 2,400 & 2,186 \\
\hline 2007 & 1,195 & 1,305 & 2,795 & 2,431 & 3,323 & 1,275 & 2,199 & 2,719 & 2,430 \\
\hline 2008 & 1,475 & 1,633 & 3,550 & 2,934 & 4,080 & 1,550 & 2,689 & 3,477 & 2,992 \\
\hline 2009 & 1,495 & 1,715 & 3,580 & 3,030 & 4,096 & 1,690 & 3,075 & 3,545 & 3,109 \\
\hline
\end{tabular}

Table continued on next page. 
Appendix Table 4. Average Reported Value of Nebraska Farmland for Different Types of Land by Agricultural Statistics District, $1978-2019^{a}$ (continued)

\begin{tabular}{|c|c|c|c|c|c|c|c|c|c|}
\hline \multirow{2}{*}{ Year } & \multicolumn{8}{c|}{ Agricultural Statistics District } \\
\cline { 2 - 8 } & Northwest & North & Northeast & Central & East & Southwest & South & Southeast & State ${ }^{\text {b }}$ \\
\hline
\end{tabular}

Gravity Irrigated Cropland

\begin{tabular}{|c|c|c|c|c|c|c|c|c|c|}
\hline 2010 & 1,625 & 1,800 & 3,715 & 3,155 & 4,510 & 1,785 & 3,095 & 3,560 & 3,271 \\
\hline 2011 & 1,980 & 2,050 & 4,500 & 3,940 & 5,725 & 1,975 & 3,940 & 4,300 & 4,071 \\
\hline 2012 & 2,440 & 2,625 & 6,250 & 5,215 & 7,420 & 2,865 & 5,170 & 5,800 & 5,365 \\
\hline 2013 & 2,875 & 3,100 & 7,850 & 6,900 & 8,750 & 3,850 & 7,060 & 7,715 & 6,835 \\
\hline 2014 & 3,040 & 4,215 & 7,455 & 8,065 & 8,750 & 4,515 & 7,290 & 8,330 & 7,310 \\
\hline 2015 & 3,235 & 4,135 & 7,355 & 6,905 & 8,445 & 4,435 & 7,095 & 7,995 & 6,900 \\
\hline 2016 & 2,970 & 3,970 & 7,220 & 6,560 & 8,115 & 4,390 & 6,265 & 7,375 & 6,480 \\
\hline 2017 & 2,580 & 3,835 & 6,890 & 6,195 & 7,640 & 4,155 & 6,020 & 6,615 & 6,070 \\
\hline 2018 & 2,340 & 3,645 & 6,680 & 5,775 & 7,455 & 3,910 & 5,795 & 6,295 & 5,795 \\
\hline 2019 & 2,245 & 3,570 & 6,510 & 5,860 & 7,585 & 3,700 & 5,365 & 5,900 & 5,690 \\
\hline
\end{tabular}

Table continued on next page. 
Appendix Table 4. Average Reported Value of Nebraska Farmland for Different Types of Land by Agricultural Statistics District, $1978-2019^{a}$ (continued)

\begin{tabular}{|c|c|c|c|c|c|c|c|c|c|}
\hline \multirow{2}{*}{ Year } & \multicolumn{7}{|c|}{ Agricultural Statistics District } \\
\cline { 2 - 9 } & Northwest & North & Northeast & Central & East & Southwest & South & Southeast & State ${ }^{\text {b }}$ \\
\hline
\end{tabular}

- . . . . . . . . - Dollars per Acre- . . . . . . . . -

Center Pivot Irrigated Cropland ${ }^{c}$

\begin{tabular}{|c|c|c|c|c|c|c|c|c|c|}
\hline 1978 & 771 & 678 & 956 & 877 & 1,484 & 813 & 1,023 & 1,286 & 1,015 \\
\hline 1979 & 915 & 770 & 1164 & 1,076 & 1,690 & 895 & 1,291 & 1,590 & 1,201 \\
\hline 1980 & 894 & 886 & 1,372 & 1,223 & 2,043 & 971 & 1,535 & 1,795 & 1,384 \\
\hline 1981 & 973 & 816 & 1,456 & 1,312 & 2,110 & 1,105 & 1,732 & 1,900 & 1,470 \\
\hline 1982 & 989 & 810 & 1,332 & 1,270 & 2,010 & 1,123 & 1,681 & 1,748 & 1,410 \\
\hline 1983 & 847 & 769 & 1,217 & 1,016 & 1,727 & 926 & 1,391 & 1,643 & 1,222 \\
\hline 1984 & 809 & 698 & 1,130 & 969 & 1,655 & 827 & 1,350 & 1,465 & 1,143 \\
\hline 1985 & 691 & 581 & 875 & 850 & 1,243 & 691 & 1,055 & 1,020 & 899 \\
\hline 1986 & 496 & 400 & 700 & 628 & 970 & 558 & 788 & 788 & 689 \\
\hline 1987 & 417 & 396 & 703 & 541 & 888 & 487 & 665 & 723 & 626 \\
\hline 1988 & 446 & 441 & 800 & 622 & 1,038 & 548 & 792 & 820 & 718 \\
\hline 1989 & 532 & 604 & 993 & 779 & 1,320 & 683 & 1,021 & 1,056 & 910 \\
\hline 1990 & 619 & 710 & 1,090 & 910 & 1,393 & 765 & 1,117 & 1,133 & 1,003 \\
\hline 1991 & 651 & 714 & 1,129 & 1,053 & 1,461 & 748 & 1,229 & 1,194 & 1,060 \\
\hline 1992 & 681 & 740 & 1,084 & 1,085 & 1,510 & 783 & 1,263 & 1,228 & 1,083 \\
\hline 1993 & 641 & 745 & 1,156 & 1,160 & 1,593 & 799 & 1,356 & 1,346 & 1,140 \\
\hline 1994 & 690 & 800 & 1,215 & 1,200 & 1,707 & 850 & 1,425 & 1,413 & 1,206 \\
\hline 1995 & 693 & 825 & 1,254 & 1,268 & 1,793 & 882 & 1,454 & 1,474 & 1,254 \\
\hline 1996 & 710 & 913 & 1,320 & 1,340 & 1,930 & 981 & 1,550 & 1,565 & 1,342 \\
\hline 1997 & 748 & 962 & 1,427 & 1,507 & 2,111 & 1,058 & 1,696 & 1,725 & 1,465 \\
\hline 1998 & 829 & 1,020 & 1,583 & 1,698 & 2,332 & 1,139 & 1,863 & 1,907 & 1,614 \\
\hline 1999 & 750 & 984 & 1,581 & 1,616 & 2,288 & 1,124 & 1,830 & 1,806 & 1,569 \\
\hline 2000 & 750 & 981 & 1,609 & 1,579 & 2,424 & 1,192 & 1,795 & 1,810 & 1,600 \\
\hline 2001 & 742 & 965 & 1,653 & 1,602 & 2,420 & 1,152 & 1,778 & 1,898 & 1,608 \\
\hline 2002 & 775 & 1,043 & 1,775 & 1,693 & 2,401 & 1,167 & 1,830 & 1,959 & 1,660 \\
\hline 2003 & 750 & 1,075 & 1,840 & 1,785 & 2,460 & 1,033 & 1,846 & 1,981 & 1,679 \\
\hline 2004 & 806 & 1,211 & 2,004 & 1,901 & 2,669 & 1,123 & 2,044 & 2,218 & 1,833 \\
\hline 2005 & 924 & 1,342 & 2,234 & 2,140 & 3,042 & 1,279 & 2,145 & 2,414 & 2,045 \\
\hline 2006 & 967 & 1,480 & 2,600 & 2,224 & 3,253 & 1,344 & 2,010 & 2,743 & 2,197 \\
\hline 2007 & 1,112 & 1,733 & 3,077 & 2,521 & 3,646 & 1,575 & 2,254 & 3,055 & 2,509 \\
\hline 2008 & 1,400 & 2,221 & 3,871 & 3,082 & 4,464 & 2,071 & 3,034 & 3,818 & 3,157 \\
\hline 2009 & 1,535 & 2,378 & 3,912 & 3,277 & 4,422 & 2,391 & 3,474 & 3,850 & 3,304 \\
\hline
\end{tabular}

Table continued on next page. 
Appendix Table 4. Average Reported Value of Nebraska Farmland for Different Types of Land by Agricultural Statistics District, $1978-2019^{a}$ (continued)

\begin{tabular}{|c|c|c|c|c|c|c|c|c|c|}
\hline \multirow{2}{*}{ Year } & \multicolumn{9}{|c|}{ Agricultural Statistics District } \\
\hline & Northwest & North & Northeast & Central & East & Southwest & South & Southeast & State $^{b}$ \\
\hline
\end{tabular}

Center Pivot Irrigated Cropland ${ }^{c}$

$\begin{array}{lrrrrrrrrr}\mathbf{2 0 1 0} & 1,650 & 2,485 & 4,140 & 3,470 & 4,890 & 2,475 & 3,575 & 4,125 & 3,520 \\ \mathbf{2 0 1 1} & 1,975 & 2,955 & 5,100 & 4,530 & 6,175 & 2,760 & 4,470 & 5,020 & 4,343 \\ \mathbf{2 0 1 2} & 2,535 & 3,970 & 7,100 & 6,190 & 7,950 & 3,830 & 5,925 & 6,820 & 5,835 \\ \mathbf{2 0 1 3} & 3,115 & 5,225 & 8,715 & 8,120 & 10,025 & 5,200 & 8,350 & 9,400 & 7,590 \\ \mathbf{2 0 1 4} & 3,700 & 4,985 & 8,855 & 8,940 & 9,860 & 5,750 & 8,440 & 9,760 & 7,685 \\ \mathbf{2 0 1 5} & 3,625 & 4,835 & 8,150 & 7,825 & 9,575 & 5,790 & 8,270 & 9,425 & 7,315 \\ \mathbf{2 0 1 6} & 3,290 & 4,350 & 7,880 & 7,530 & 9,410 & 5,330 & 7,240 & 9,185 & 6,940 \\ \mathbf{2 0 1 7} & 2,815 & 4,150 & 7,445 & 6,885 & 8,700 & 4,510 & 6,700 & 7,820 & 6,295 \\ \mathbf{2 0 1 8} & 2,700 & 4,020 & 7,310 & 6,510 & 8,645 & 4,265 & 6,520 & 7,720 & 6,130 \\ \mathbf{2 0 1 9} & 2,565 & 3,905 & 7,210 & 6,390 & 8,485 & 4,110 & 6,150 & 7,470 & 5,970\end{array}$

Table continued on next page. 
Appendix Table 4. Average Reported Value of Nebraska Farmland for Different Types of Land by Agricultural Statistics District, $1978-2019^{a}$ (continued)

\begin{tabular}{|c|c|c|c|c|c|c|c|c|c|}
\hline \multirow{2}{*}{ Year } & \multicolumn{7}{|c|}{ Agricultural Statistics District } \\
\cline { 2 - 9 } & Northwest & North & Northeast & Central & East & Southwest & South & Southeast & State \\
\hline
\end{tabular}

- . . . . . . . . - Dollars per Acre- . . . . . . . . .

All-Land Average ${ }^{\mathrm{d}}$

\begin{tabular}{|c|c|c|c|c|c|c|c|c|c|}
\hline 1978 & 261 & 205 & 686 & 571 & 1,116 & 659 & 747 & 810 & 489 \\
\hline 1979 & 290 & 248 & 846 & 669 & 1,348 & 402 & 914 & 1,005 & 584 \\
\hline 1980 & 310 & 274 & 998 & 764 & 1,634 & 465 & 1,069 & 1,165 & 677 \\
\hline 1981 & 366 & 275 & 1,078 & 826 & 1,709 & 531 & 1,206 & 1,219 & 729 \\
\hline 1982 & 365 & 273 & 998 & 803 & 1,611 & 518 & 1,199 & 1,138 & 701 \\
\hline 1983 & 319 & 251 & 898 & 687 & 1,411 & 46 & 997 & 1,068 & 621 \\
\hline 1984 & 299 & 232 & 833 & 617 & 1,319 & 426 & 954 & 957 & 574 \\
\hline 1985 & 244 & 182 & 661 & 511 & 996 & 338 & 765 & 669 & 446 \\
\hline 1986 & 181 & 137 & 518 & 371 & 746 & 266 & 538 & 498 & 335 \\
\hline 1987 & 157 & 116 & 505 & 318 & 700 & 231 & 466 & 167 & 305 \\
\hline 1988 & 165 & 126 & 572 & 375 & 805 & 243 & 539 & 558 & 342 \\
\hline 1989 & 199 & 173 & 697 & 478 & 998 & 306 & 675 & 688 & 428 \\
\hline 1990 & 209 & 206 & 756 & 561 & 1,059 & 340 & 735 & 738 & 470 \\
\hline 1991 & 217 & 216 & 762 & 627 & 1,103 & 341 & 792 & 743 & 490 \\
\hline 1992 & 230 & 229 & 748 & 648 & 1,145 & 350 & 825 & 777 & 506 \\
\hline 1993 & 229 & 229 & 804 & 683 & 1,206 & 351 & 884 & 825 & 528 \\
\hline 1994 & 239 & 248 & 852 & 716 & 1,310 & 378 & 936 & 872 & 563 \\
\hline 1995 & 240 & 256 & 879 & 739 & 1,368 & 389 & 949 & 903 & 581 \\
\hline 1996 & 245 & 262 & 915 & 765 & 1,470 & 409 & 990 & 952 & 608 \\
\hline 1997 & 261 & 281 & 985 & 839 & 1,595 & 432 & 1,071 & 1,033 & 657 \\
\hline 1998 & 279 & 301 & 1,083 & 916 & 1,754 & 468 & 1,153 & 1,141 & 716 \\
\hline 1999 & 266 & 291 & 1,081 & 878 & 1,722 & 457 & 1,121 & 1,098 & 697 \\
\hline 2000 & 268 & 306 & 1,097 & 864 & 1,760 & 480 & 1,087 & 1,105 & 707 \\
\hline 2001 & 265 & 318 & 1,136 & 879 & 1,771 & 484 & 1,091 & 1,129 & 719 \\
\hline 2002 & 275 & 325 & 1,226 & 931 & 1,784 & 505 & 1,118 & 1,193 & 746 \\
\hline 2003 & 270 & 312 & 1,270 & 976 & 1,860 & 471 & 1,130 & 1,201 & 756 \\
\hline 2004 & 293 & 348 & 1,392 & 1,044 & 2,011 & 505 & 1,221 & 1,347 & 824 \\
\hline 2005 & 317 & 385 & 1,542 & 1,156 & 2,284 & 550 & 1,296 & 1,507 & 914 \\
\hline 2006 & 342 & 431 & 1,782 & 1,240 & 2,508 & 584 & 1,249 & 1,696 & 1,001 \\
\hline 2007 & 388 & 513 & 2,145 & 1,384 & 2,813 & 644 & 1,377 & 1,942 & 1,145 \\
\hline 2008 & 452 & 606 & 2,726 & 1,681 & 3,490 & 780 & 1,763 & 2,451 & 1,414 \\
\hline 2009 & 461 & 604 & 2,692 & 1,698 & 3,418 & 847 & 1,977 & 2,503 & 1,431 \\
\hline
\end{tabular}

Table continued on next page. 


\section{Appendix Table 4. Average Reported Value of Nebraska Farmland for Different Types of Land by Agricultural Statistics District, 1978-2019 ${ }^{a}$ (continued)}

\begin{tabular}{|c|c|c|c|c|c|c|c|c|c|}
\hline \multirow{2}{*}{ Year } & \multicolumn{9}{|c|}{ Agricultural Statistics District } \\
\hline & Northwest & North & Northeast & Central & East & Southwest & South & Southeast & State $^{b}$ \\
\hline & \multicolumn{9}{|c|}{ 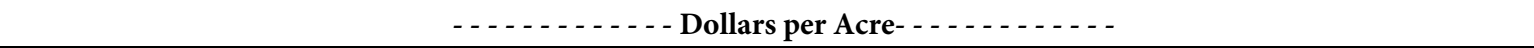 } \\
\hline \multicolumn{10}{|c|}{ All-Land Average ${ }^{\mathrm{d}}$} \\
\hline 2010 & 463 & 598 & 2,898 & 1,748 & 3,762 & 870 & 2,029 & 2,596 & 1,503 \\
\hline 2011 & 520 & 706 & 3,624 & 2,183 & 4,225 & 991 & 2,535 & 3,160 & 1,833 \\
\hline 2012 & 635 & 875 & 4,975 & 2,945 & 6,080 & 1,335 & 3,355 & 4,280 & 2,425 \\
\hline 2013 & 715 & 1,055 & 6,165 & 3,750 & 7,185 & 1,750 & 4,460 & 5,400 & 3,040 \\
\hline 2014 & 855 & 1,220 & 6,460 & 4,195 & 7,285 & 1,985 & 4,815 & 6,185 & 3,315 \\
\hline 2015 & 860 & 1,330 & 6,140 & 3,955 & 7,100 & 2,065 & 4,625 & 5,990 & 3,250 \\
\hline 2016 & 820 & 1,245 & 5,980 & 3,780 & 6,990 & 1,960 & 4,255 & 5,675 & 3,115 \\
\hline 2017 & 755 & 1,170 & 5,505 & 3,385 & 6,395 & 1,745 & 3,875 & 4,880 & 2,820 \\
\hline 2018 & 715 & 1,090 & 5,395 & 3,165 & 6,240 & 1,650 & 3,750 & 4,815 & 2,720 \\
\hline 2019 & 680 & 1,050 & 5,230 & 3,090 & 6,185 & 1,565 & 3,535 & 4,700 & 2,645 \\
\hline
\end{tabular}

Source: ${ }^{a}$ Average reported from the UNL Nebraska Farm Real Estate Market Surveys, 1978-2019.

${ }^{\mathrm{b}}$ Weighted average based upon acreage in each land type.

${ }^{\mathrm{c}}$ Pivot not included in per acre value.

${ }^{\mathrm{d}}$ All-land average for the state may not conform to USDA series due to different acreage weighting. In addition, the USDA series includes farm buildings in the per acre estimates of value. 
Appendix Table 5. Historical Per Acre Value Range for Different Types and Quality Grades of Land in Nebraska by Agricultural Statistics District, 2015-2019

\begin{tabular}{|c|c|c|c|c|c|c|c|c|c|c|}
\hline \multirow{3}{*}{ District and Type of Land } & \multicolumn{10}{|c|}{ Reported Value Per Acre } \\
\hline & \multicolumn{5}{|c|}{ Low Grade } & \multicolumn{5}{|c|}{ High Grade } \\
\hline & 2015 & 2016 & 2017 & 2018 & 2019 & 2015 & 2016 & 2017 & 2018 & 2019 \\
\hline & \multicolumn{10}{|c|}{ 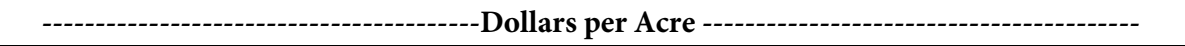 } \\
\hline \multicolumn{11}{|l|}{ Northwest: } \\
\hline Dry Crop (No Irr. Potential) & 580 & 555 & 540 & 485 & 475 & 935 & 965 & 935 & 910 & 820 \\
\hline Dry Crop (Irr. Pot.) & 785 & 600 & 565 & 525 & 505 & 1,080 & 910 & 895 & 880 & 870 \\
\hline Grazing (Tillable) & 485 & 485 & 450 & 430 & 420 & 715 & 620 & 615 & 600 & 605 \\
\hline Grazing (Nontillable) & 415 & 420 & 400 & 380 & 360 & 605 & 590 & 585 & 570 & 550 \\
\hline Hayland & 850 & 650 & 685 & 665 & 520 & 1,275 & 1,010 & 885 & 875 & 815 \\
\hline Gravity Irrigated & 3,065 & 2,610 & 2,250 & 1,900 & 1,710 & 4,465 & 3,890 & 3,475 & 3,220 & 2,980 \\
\hline Center Pivot Irrigated ${ }^{\mathrm{b}}$ & 3,415 & 3,100 & 2,385 & 2,055 & 2,060 & 4,925 & 4,415 & 3,265 & 3,030 & 3,105 \\
\hline \multicolumn{11}{|l|}{ North: } \\
\hline Dry Crop (No Irr. Potential) & 1,440 & 1,565 & 1,430 & 1,330 & 1,285 & 2,150 & 2,220 & 2,080 & 1,945 & 1,845 \\
\hline Dry Crop (Irr. Pot.) & 1,965 & 1,910 & 1,810 & 1,740 & 1,715 & 3,065 & 2,685 & 2,450 & 2,305 & 2,265 \\
\hline Grazing (Tillable) & 1,250 & 1,120 & 1,035 & 995 & 945 & 1,905 & 1,775 & 1,425 & 1,375 & 1,265 \\
\hline Grazing (Nontillable) & 615 & 630 & 620 & 585 & 500 & 975 & 940 & 935 & 885 & 870 \\
\hline Hayland & 1,535 & 1,110 & 1,085 & 1,040 & 1,000 & 2,250 & 1,710 & 1,585 & 1,470 & 1,390 \\
\hline Gravity Irrigated & 3,325 & 2,870 & 2,800 & 2,715 & 2,700 & 4,745 & 4,520 & 4,265 & 4,170 & 4,080 \\
\hline Center Pivot Irrigated ${ }^{\mathrm{b}}$ & 4,435 & 3,935 & 3,750 & 3,595 & 3,380 & 5,985 & 5,620 & 5,560 & 5,010 & 4,975 \\
\hline \multicolumn{11}{|l|}{ Northeast: } \\
\hline Dry Crop (No Irr. Potential) & 4,475 & 4,140 & 4,020 & 4,045 & 3,960 & 7,085 & 7,010 & 6,980 & 6,550 & 6,420 \\
\hline Dry Crop (Irr. Pot.) & 5,345 & 4,930 & 4,805 & 4,905 & 4,745 & 8,190 & 7,280 & 7,250 & 6,600 & 6,310 \\
\hline Grazing (Tillable) & 3,070 & 2,830 & 2,560 & 2,580 & 2,490 & 4,270 & 4,240 & 3,910 & 3,780 & 3,715 \\
\hline Grazing (Nontillable) & 1,975 & 1,935 & 1,820 & 1,705 & 1,680 & 3,040 & 2,865 & 2,860 & 2,830 & 2,670 \\
\hline Hayland & 3,235 & 2,995 & 2,520 & 2,485 & 2,225 & 4,350 & 4,305 & 3,825 & 3,755 & 3,630 \\
\hline Gravity Irrigated & 6,250 & 6,480 & 5,895 & 5,860 & 5,610 & 9,050 & 8,810 & 8,555 & 8,120 & 7,940 \\
\hline Center Pivot Irrigated ${ }^{\mathrm{b}}$ & 6,650 & 7,015 & 6,350 & 6,140 & 5,910 & 9,245 & 9,240 & 8,875 & 8,295 & 8,240 \\
\hline \multicolumn{11}{|l|}{ Central: } \\
\hline Dry Crop (No Irr. Potential) & 2,285 & 2,490 & 2,105 & 2,060 & 2,030 & 3,635 & 3,940 & 3,160 & 3,080 & 3,155 \\
\hline Dry Crop (Irr. Pot.) & 3,795 & 2,970 & 2,520 & 2,435 & 2,380 & 4,430 & 4,400 & 3,640 & 3,540 & 3,515 \\
\hline Grazing (Tillable) & 2,015 & 2,250 & 1,600 & 1,530 & 1,500 & 3,050 & 2,930 & 2,445 & 2,220 & 2,175 \\
\hline Grazing (Nontillable) & 1,470 & 1,655 & 1,190 & 1,115 & 1,050 & 2,390 & 2,340 & 1,905 & 1,865 & 1,765 \\
\hline Hayland & 2,260 & 2,300 & 1,800 & 1,740 & 1,560 & 3,110 & 3,015 & 2,350 & 2,065 & 2,040 \\
\hline Gravity Irrigated & 5,370 & 5,240 & 5,205 & 4,885 & 4,875 & 7,600 & 7,575 & 6,925 & 6,285 & 6,415 \\
\hline Center Pivot Irrigated ${ }^{b}$ & 5,830 & 6,255 & 5,845 & 5,445 & 5,195 & 8,475 & 8,200 & 7,900 & 7,240 & 7,190 \\
\hline
\end{tabular}

Table continued on next page. 
Appendix Table 5. Historical Per Acre Value Range for Different Types and Quality Grades of Land in Nebraska by Agricultural Statistics District, 2015-2019ª (continued)

\begin{tabular}{|c|c|c|c|c|c|c|c|c|c|c|}
\hline \multirow{3}{*}{ District and Type of land } & \multicolumn{10}{|c|}{ Reported Value Per Acre } \\
\hline & \multicolumn{5}{|c|}{ Low Grade } & \multicolumn{5}{|c|}{ High Grade } \\
\hline & 2015 & 2016 & 2017 & 2018 & 2019 & 2015 & 2016 & 2017 & 2018 & 2019 \\
\hline & --- & & & 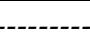 & Dollars & er Acre & 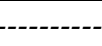 & $---\cdot-$ & 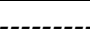 & --- \\
\hline \multicolumn{11}{|l|}{ East: } \\
\hline Dry Crop (No Irr. Potential) & 4,650 & 4,820 & 4,610 & 4,515 & 4,450 & 7,595 & 7,635 & 6,945 & 6,865 & 6,870 \\
\hline Dry Crop (Irr. Pot.) & 5,490 & 5,660 & 5,050 & 4,875 & 4,865 & 8,240 & 8,435 & 7,225 & 7,005 & 7,000 \\
\hline Grazing (Tillable) & 2,840 & 2,890 & 2,765 & 2,590 & 2,420 & 4,475 & 4,560 & 4,110 & 3,955 & 3,910 \\
\hline Grazing (Nontillable) & 2,135 & 2,005 & 1,925 & 1,900 & 1,885 & 3,275 & 3,290 & 2,950 & 2,635 & 2,600 \\
\hline Hayland & 2,955 & 2,440 & 2,310 & 2,225 & 2,415 & 4,340 & 3,675 & 3,565 & 3,615 & 3,335 \\
\hline Gravity Irrigated & 7,335 & 7,190 & 6,530 & 6,355 & 6,340 & 9,550 & 9,175 & 8,765 & 8,315 & 8,500 \\
\hline Center Pivot Irrigated ${ }^{\mathrm{b}}$ & 7,915 & 8,035 & 7,315 & 7,320 & 6,985 & 10,885 & 10,410 & 9,670 & 9,560 & 9,520 \\
\hline \multicolumn{11}{|l|}{ Southwest: } \\
\hline Dry Crop (No Irr. Potential) & 1,260 & 1,480 & 1,170 & 1,045 & 1,010 & 2,180 & 2,395 & 2,095 & 1,960 & 1,620 \\
\hline Dry Crop (Irr. Pot.) & 1,765 & 1,670 & 1,540 & 1,435 & 1,325 & 2,615 & 2,430 & 2,065 & 1,885 & 1,760 \\
\hline Grazing (Tillable) & 940 & 895 & 865 & 860 & 785 & 1,340 & 1,255 & 1,195 & 1,080 & 1,060 \\
\hline Grazing (Nontillable) & 705 & 825 & 650 & 625 & 610 & 1,150 & 1,160 & 965 & 870 & 820 \\
\hline Hayland & 1,370 & 1,285 & 1,205 & 1,150 & 1,040 & 2,440 & 1,935 & 1,620 & 1,465 & 1,490 \\
\hline Gravity Irrigated & 4,260 & 4,135 & 3,280 & 3,040 & 2,990 & 5,860 & 5,670 & 4,580 & 4,405 & 4,235 \\
\hline Center Pivot Irrigated ${ }^{\mathrm{b}}$ & 4,880 & 4,840 & 3,810 & 3,690 & 3,615 & 7,055 & 6,890 & 5,320 & 4,905 & 4,890 \\
\hline \multicolumn{11}{|l|}{ South: } \\
\hline Dry Crop (No Irr. Potential) & 2,465 & 2,405 & 2,205 & 2,180 & 2,165 & 4,050 & 4,440 & 3,625 & 3,315 & 3,300 \\
\hline Dry Crop (Irr. Pot.) & 3,125 & 2,940 & 2,740 & 2,890 & 2,810 & 4,750 & 4,685 & 4,400 & 4,150 & 4,140 \\
\hline Grazing (Tillable) & 1,725 & 1,580 & 1,450 & 1,505 & 1,485 & 2,575 & 2,440 & 2,370 & 2,150 & 2,110 \\
\hline Grazing (Nontillable) & 1,320 & 1,355 & 1,330 & 1,300 & 1,215 & 2,310 & 1,980 & 1,945 & 1,850 & 1,725 \\
\hline Hayland & 2,455 & 1,525 & 1,490 & 1,510 & 1,415 & 3,500 & 2,950 & 2,875 & 2,605 & 2,600 \\
\hline Gravity Irrigated & 5,775 & 4,585 & 4,420 & 4,225 & 4,185 & 8,660 & 7,970 & 7,060 & 6,725 & 6,520 \\
\hline Center Pivot Irrigated ${ }^{\mathrm{b}}$ & 6,675 & 5,710 & 5,530 & 5,400 & 5,625 & 9,155 & 8,355 & 7,840 & 7,645 & 7,395 \\
\hline \multicolumn{11}{|l|}{ Southeast: } \\
\hline Dry Crop (No Irr. Potential) & 3,560 & 3,305 & 3,075 & 3,005 & 2,940 & 6,655 & 5,910 & 5,060 & 5,095 & 5,100 \\
\hline Dry Crop (Irr. Pot.) & 5,030 & 4,310 & 4,030 & 3,920 & 3,905 & 8,325 & 7,635 & 6,315 & 6,195 & 6,175 \\
\hline Grazing (Tillable) & 2,635 & 2,580 & 2,305 & 2,190 & 2,140 & 3,815 & 3,430 & 3,195 & 3,270 & 3,125 \\
\hline Grazing (Nontillable) & 1,865 & 1,735 & 1,900 & 1,720 & 1,740 & 2,905 & 2,630 & 2,190 & 2,175 & 2,120 \\
\hline Hayland & 2,505 & 2,330 & 2,290 & 2,190 & 2,025 & 3,350 & 3,290 & 3,060 & 3,270 & 3,315 \\
\hline Gravity Irrigated & 6,650 & 6,800 & 5,500 & 4,890 & 4,870 & 8,895 & 8,525 & 7,140 & 7,125 & 7,120 \\
\hline Center Pivot Irrigated ${ }^{b}$ & 7,320 & 7,400 & 6,490 & 6,230 & 6,105 & 10,645 & 9,865 & 8,330 & 8,495 & 8,430 \\
\hline
\end{tabular}

Source: ${ }^{a}$ UNL Nebraska Farm Real Estate Market Surveys, 2015-2019.

${ }^{\mathrm{b}}$ Pivot not included in per acre value. 
Appendix Table 6. Estimated Annual Net Rates of Return to Nebraska Farmland for Different Types of Land by Agricultural Statistics District, 1990-2019

\begin{tabular}{|c|c|c|c|c|c|c|c|c|c|}
\hline \multirow{2}{*}{ Year } & \multicolumn{9}{|c|}{ Agricultural Statistics District } \\
\cline { 2 - 8 } & Northwest & North & Northeast & Central & East & Southwest & South & Southeast & State \\
\hline
\end{tabular}

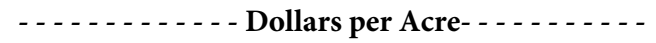

Dryland Cropland

\begin{tabular}{|c|c|c|c|c|c|c|c|c|c|}
\hline 1990 & 6.2 & 6.3 & 5.9 & 6.4 & 5.9 & 4.7 & 6.1 & 6.3 & 6.0 \\
\hline 1991 & 5.9 & 5.0 & 6.0 & 5.9 & 5.8 & 4.7 & 6.1 & 5.8 & 5.7 \\
\hline 1992 & 4.8 & 5.0 & 5.6 & 5.9 & 5.7 & 5.6 & 5.2 & 6.1 & 5.5 \\
\hline 1993 & 5.0 & 4.3 & 5.8 & 5.7 & 5.3 & 5.3 & 6.1 & 5.2 & 5.4 \\
\hline 1994 & 4.5 & 5.2 & 6.0 & 5.4 & 5.2 & 5.2 & 5.3 & 5.4 & 5.3 \\
\hline 1995 & 4.2 & 6.0 & 6.2 & 5.3 & 5.2 & 5.1 & 5.4 & 5.0 & 5.3 \\
\hline 1996 & 4.1 & 5.0 & 6.3 & 5.6 & 5.0 & 5.3 & 5.5 & 5.2 & 5.3 \\
\hline 1997 & 5.1 & 5.8 & 6.4 & 5.6 & 5.3 & 5.3 & 5.4 & 5.4 & 5.5 \\
\hline 1998 & 4.5 & 5.5 & 5.8 & 5.3 & 4.8 & 4.8 & 5.4 & 5.0 & 5.1 \\
\hline 1999 & 4.3 & 4.9 & 5.4 & 5.1 & 4.5 & 3.9 & 4.5 & 4.9 & 4.7 \\
\hline 2000 & 4.0 & 5.2 & 5.4 & 5.1 & 4.7 & 4.5 & 4.7 & 5.0 & 4.8 \\
\hline 2001 & 4.1 & 5.3 & 5.5 & 5.0 & 4.6 & 4.3 & 4.6 & 4.7 & 4.8 \\
\hline 2002 & 4.0 & 4.6 & 5.3 & 5.1 & 4.5 & 4.7 & 4.6 & 4.9 & 4.7 \\
\hline 2003 & 3.6 & 4.5 & 4.8 & 4.6 & 4.1 & 4.1 & 4.7 & 4.4 & 4.4 \\
\hline 2004 & 3.5 & 4.4 & 4.5 & 4.3 & 3.8 & 3.9 & 4.4 & 4.6 & 4.2 \\
\hline 2005 & 3.6 & 3.9 & 4.2 & 4.5 & 3.5 & 4.0 & 4.6 & 4.4 & 4.1 \\
\hline 2006 & 3.5 & 4.4 & 3.6 & 4.2 & 3.4 & 3.8 & 4.6 & 4.1 & 4.0 \\
\hline 2007 & 4.1 & 4.4 & 4.3 & 4.6 & 3.4 & 3.7 & 4.8 & 4.0 & 4.1 \\
\hline 2008 & 4.5 & 4.8 & 4.4 & 4.7 & 3.9 & 4.0 & 5.0 & 4.4 & 4.5 \\
\hline 2009 & 4.0 & 4.0 & 4.0 & 4.3 & 3.5 & 3.5 & 4.1 & 3.8 & 3.9 \\
\hline 2010 & 4.1 & 3.5 & 4.1 & 3.7 & 3.2 & 4.1 & 4.0 & 3.7 & 3.8 \\
\hline 2011 & 3.8 & 3.7 & 3.8 & 3.8 & 3.5 & 3.5 & 4.0 & 3.5 & 3.7 \\
\hline 2012 & 4.0 & 4.0 & 3.3 & 3.7 & 3.2 & 3.2 & 3.3 & 3.2 & 3.5 \\
\hline 2013 & 3.5 & 2.9 & 3.3 & 2.8 & 2.8 & 3.0 & 1.9 & 2.7 & 2.9 \\
\hline 2014 & 3.5 & 2.4 & 3.0 & 2.5 & 3.0 & 2.6 & 2.2 & 2.5 & 2.8 \\
\hline 2015 & 3.4 & 2.4 & 2.9 & 2.4 & 2.6 & 2.5 & 2.3 & 2.4 & 2.6 \\
\hline 2016 & 3.6 & 2.5 & 3.0 & 2.7 & 2.6 & 2.4 & 2.2 & 2.5 & 2.7 \\
\hline 2017 & 3.5 & 2.4 & 2.8 & 2.5 & 2.3 & 2.5 & 2.2 & 2.4 & 2.6 \\
\hline 2018 & 3.3 & 2.5 & 2.7 & 2.6 & 2.2 & 2.4 & 2.4 & 2.3 & 2.5 \\
\hline 2019 & 3.1 & 2.4 & 2.6 & 2.5 & 24 & 2.2 & 2.3 & 2.2 & 2.5 \\
\hline
\end{tabular}

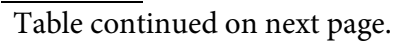


Appendix Table 6. Estimated Annual Net Rates of Return to Nebraska Farmland for Different Types of Land by Agricultural Statistics District, 1990-2019 ${ }^{\text {ab }}$ (continued)

\begin{tabular}{|l|c|c|c|c|c|c|c|c|c|}
\hline \multirow{2}{*}{ Year } & \multicolumn{8}{|c|}{ Agricultural Statistics District } \\
\cline { 2 - 10 } & Northwest & North & Northeast & Central & East & Southwest & South & Southeast & State \\
\hline
\end{tabular}

- . . . . . . . . - Dollars per Acre- . . . . . . . . .

Irrigated Cropland

\begin{tabular}{|c|c|c|c|c|c|c|c|c|c|}
\hline 1990 & 8.3 & 9.3 & 6.9 & 6.8 & 6.7 & 6.3 & 6.3 & 6.0 & 7.1 \\
\hline 1991 & 8.7 & 8.0 & 6.8 & 6.5 & 6.4 & 6.4 & 6.2 & 5.9 & 6.9 \\
\hline 1992 & 6.8 & 6.5 & 6.6 & 6.6 & 6.0 & 6.5 & 6.0 & 6.1 & 6.4 \\
\hline 1993 & 6.6 & 6.0 & 6.5 & 6.1 & 5.7 & 6.5 & 6.5 & 6.0 & 6.2 \\
\hline 1994 & 6.9 & 6.5 & 6.3 & 6.3 & 5.6 & 6.2 & 5.7 & 5.7 & 6.2 \\
\hline 1995 & 6.6 & 6.8 & 6.5 & 5.9 & 5.3 & 5.9 & 6.0 & 5.0 & 6.0 \\
\hline 1996 & 6.7 & 6.3 & 6.9 & 5.8 & 5.2 & 6.5 & 6.2 & 5.4 & 6.1 \\
\hline 1997 & 7.2 & 7.0 & 7.0 & 6.0 & 5.3 & 6.7 & 6.3 & 5.7 & 6.4 \\
\hline 1998 & 6.7 & 6.7 & 6.0 & 5.8 & 5.0 & 6.6 & 5.7 & 5.4 & 6.0 \\
\hline 1999 & 6.0 & 5.9 & 5.9 & 5.3 & 4.6 & 6.1 & 4.9 & 5.0 & 5.5 \\
\hline 2000 & 6.0 & 6.2 & 6.0 & 5.6 & 5.0 & 6.3 & 5.5 & 5.0 & 5.7 \\
\hline 2001 & 5.6 & 6.2 & 5.9 & 5.4 & 4.9 & 6.5 & 5.2 & 5.0 & 5.6 \\
\hline 2002 & 5.4 & 5.9 & 5.5 & 5.3 & 4.5 & 6.2 & 5.3 & 5.1 & 5.4 \\
\hline 2003 & 5.3 & 5.8 & 5.2 & 5.2 & 4.4 & 6.3 & 5.4 & 5.1 & 5.3 \\
\hline 2004 & 5.3 & 6.1 & 5.2 & 5.2 & 4.7 & 5.6 & 5.3 & 5.3 & 5.3 \\
\hline 2005 & 5.9 & 5.9 & 4.9 & 5.0 & 4.0 & 5.6 & 5.4 & 5.0 & 5.2 \\
\hline 2006 & 5.5 & 5.8 & 4.2 & 4.9 & 3.7 & 5.4 & 5.3 & 4.4 & 4.9 \\
\hline 2007 & 5.4 & 5.9 & 4.7 & 5.0 & 3.9 & 6.0 & 5.6 & 4.9 & 5.0 \\
\hline 2008 & 6.0 & 6.0 & 4.9 & 5.2 & 4.2 & 5.8 & 5.6 & 5.1 & 5.4 \\
\hline 2009 & 5.8 & 5.0 & 4.8 & 4.7 & 3.9 & 4.8 & 4.9 & 4.6 & 4.8 \\
\hline 2010 & 5.2 & 4.7 & 4.7 & 4.6 & 3.5 & 5.0 & 4.2 & 4.2 & 4.4 \\
\hline 2011 & 5.1 & 4.5 & 4.3 & 4.4 & 3.9 & 4.8 & 4.5 & 4.2 & 4.5 \\
\hline 2012 & 4.9 & 4.8 & 3.7 & 3.6 & 3.3 & 4.0 & 3.3 & 3.6 & 3.9 \\
\hline 2013 & 4.4 & 3.5 & 3.8 & 3.1 & 3.3 & 3.7 & 2.8 & 3.0 & 3.4 \\
\hline 2014 & 4.6 & 2.7 & 3.6 & 2.5 & 3.4 & 3.4 & 2.4 & 3.1 & 3.2 \\
\hline 2015 & 4.4 & 2.6 & 3.5 & 2.4 & 3.0 & 3.3 & 2.4 & 2.8 & 3.1 \\
\hline 2016 & 4.3 & 2.5 & 3.6 & 2.6 & 2.9 & 3.2 & 2.3 & 2.8 & 3.0 \\
\hline 2017 & 4.0 & 2.6 & 3.4 & 2.7 & 2.8 & 3.1 & 2.4 & 2.7 & 3.0 \\
\hline 2018 & 3.9 & 2.7 & 3.2 & 2.5 & 2.7 & 3.1 & 2.5 & 2.6 & 2.9 \\
\hline 2019 & 3.3 & 2.6 & 3.1 & 2.4 & 2.5 & 2.9 & 2.4 & 2.5 & 2.8 \\
\hline
\end{tabular}

Table continued on next page. 
Appendix Table 6. Estimated Annual Net Rates of Return to Nebraska Farmland for Different Types of Land by Agricultural Statistics District, 1990-2019 ${ }^{\text {ab }}$ (continued)

\begin{tabular}{|c|c|c|c|c|c|c|c|c|c|}
\hline \multirow{2}{*}{ Year } & \multicolumn{8}{|c|}{ Agricultural Statistics District } \\
\cline { 2 - 10 } & Northwest & North & Northeast & Central & East & Southwest & South & Southeast & State \\
\hline
\end{tabular}

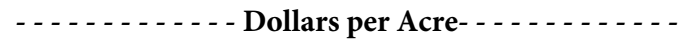

\section{Grazing Land}

\begin{tabular}{|c|c|c|c|c|c|c|c|c|c|}
\hline 1990 & 4.0 & 5.8 & 4.6 & 4.9 & 5.0 & 4.5 & 5.4 & 5.0 & 4.9 \\
\hline 1991 & 5.5 & 5.9 & 5.4 & 5.0 & 5.3 & 5.8 & 5.5 & 5.5 & 5.4 \\
\hline 1992 & 4.0 & 5.3 & 4.9 & 4.6 & 4.4 & 5.1 & 5.0 & 5.0 & 4.8 \\
\hline 1993 & 4.3 & 4.6 & 5.0 & 4.6 & 4.3 & 4.6 & 4.5 & 4.6 & 4.6 \\
\hline 1994 & 4.7 & 4.5 & 5.1 & 4.4 & 4.3 & 4.7 & 4.1 & 4.5 & 4.5 \\
\hline 1995 & 3.7 & 4.7 & 4.9 & 4.0 & 4.2 & 4.5 & 4.2 & 4.0 & 4.3 \\
\hline 1996 & 3.8 & 4.3 & 4.9 & 4.3 & 4.0 & 4.3 & 3.8 & 4.1 & 4.2 \\
\hline 1997 & 3.6 & 4.3 & 4.9 & 4.5 & 4.0 & 4.0 & 3.6 & 4.2 & 4.1 \\
\hline 1998 & 3.4 & 4.2 & 4.6 & 4.1 & 3.9 & 4.2 & 4.0 & 3.8 & 4.0 \\
\hline 1999 & 3.1 & 3.5 & 4.4 & 4.2 & 3.6 & 3.2 & 3.6 & 3.9 & 3.7 \\
\hline 2000 & 3.3 & 4.4 & 4.6 & 3.7 & 3.8 & 3.6 & 4.0 & 4.1 & 3.9 \\
\hline 2001 & 2.9 & 4.0 & 4.3 & 3.9 & 4.0 & 3.4 & 3.5 & 4.1 & 3.8 \\
\hline 2002 & 2.8 & 4.1 & 4.4 & 3.8 & 3.7 & 4.0 & 3.8 & 4.1 & 3.8 \\
\hline 2003 & 2.4 & 3.3 & 3.8 & 3.3 & 3.4 & 3.4 & 3.9 & 3.8 & 3.4 \\
\hline 2004 & 2.8 & 3.1 & 3.6 & 3.3 & 3.7 & 3.3 & 3.4 & 4.1 & 3.4 \\
\hline 2005 & 2.6 & 3.3 & 3.7 & 3.8 & 2.9 & 3.1 & 3.6 & 4.3 & 3.4 \\
\hline 2006 & 2.7 & 3.1 & 3.0 & 3.6 & 3.0 & 3.1 & 3.7 & 3.8 & 3.3 \\
\hline 2007 & 2.3 & 2.5 & 3.0 & 2.9 & 2.9 & 2.8 & 3.5 & 3.0 & 2.9 \\
\hline 2008 & 2.8 & 3.1 & 3.3 & 2.9 & 3.4 & 2.9 & 3.3 & 3.6 & 3.2 \\
\hline 2009 & 2.6 & 2.7 & 3.0 & 2.9 & 2.5 & 2.5 & 2.9 & 3.1 & 2.8 \\
\hline 2010 & 2.0 & 2.5 & 3.1 & 2.1 & 2.3 & 2.9 & 3.0 & 2.9 & 2.6 \\
\hline 2011 & 2.0 & 2.9 & 2.6 & 2.5 & 2.7 & 2.5 & 3.0 & 2.5 & 2.6 \\
\hline 2012 & 2.0 & 2.4 & 2.4 & 2.4 & 2.0 & 2.2 & 3.1 & 2.2 & 2.4 \\
\hline 2013 & 1.9 & 2.3 & 2.4 & 1.6 & 2.0 & 1.8 & 1.7 & 1.7 & 1.9 \\
\hline 2014 & 2.1 & 2.0 & 2.1 & 1.7 & 1.9 & 2.1 & 1.7 & 1.4 & 1.7 \\
\hline 2015 & 2.3 & 2.6 & 2.7 & 2.1 & 2.2 & 2.6 & 2.2 & 1.7 & 2.3 \\
\hline 2016 & 2.2 & 2.7 & 2.6 & 2.1 & 2.0 & 2.3 & 2.1 & 1.5 & 2.2 \\
\hline 2017 & 2.1 & 2.5 & 2.4 & 2.0 & 1.7 & 2.1 & 1.9 & 1.6 & 2.0 \\
\hline 2018 & 2.1 & 2.6 & 2.2 & 1.9 & 1.8 & 2.0 & 1.8 & 1.7 & 2.0 \\
\hline 2019 & 2.0 & 2.3 & 2.1 & 1.7 & 1.8 & 1.9 & 2.0 & 1.6 & 1.9 \\
\hline
\end{tabular}

Source: ${ }^{\text {a }}$ Panel members reported annual estimates of net rates of return in the annual UNL Nebraska Farm Real Estate Market Surveys, 1990-2019.

${ }^{\mathrm{b}}$ Panel members reported estimates of annual net returns as percentage rates of current land values. Real estate appraisers refer to this percentage as the market-derived capitalization rate. 
Appendix Table 7. Historical Average Cash Rental Rates of Nebraska Farmland for Different Types of Land by Agricultural Statistics District, 1981-2019a

\begin{tabular}{|c|c|c|c|c|c|c|c|c|}
\hline $\begin{array}{c}\text { Type of } \\
\text { Land and } \\
\text { Year }\end{array}$ & \multicolumn{8}{|c|}{ Agricultural Statistics District } \\
\cline { 2 - 8 } & Northwest & North & Northeast & Central & East & Southwest & South & Southeast \\
\hline
\end{tabular}

Dryland Cropland

\begin{tabular}{|c|c|c|c|c|c|c|c|c|}
\hline 1981 & $\mathrm{~b}$ & $b$ & 60 & 43 & 68 & 35 & 38 & 55 \\
\hline 1982 & b & $\mathrm{b}$ & 67 & 38 & 71 & 34 & 38 & 60 \\
\hline 1983 & b & $b$ & 63 & 43 & 66 & 25 & 41 & 57 \\
\hline 1984 & $\mathrm{~b}$ & $b$ & 63 & 41 & 72 & 29 & 44 & 57 \\
\hline 1985 & b & $\mathrm{b}$ & 55 & 38 & 65 & 26 & 40 & 50 \\
\hline 1986 & $\mathrm{~b}$ & $\mathrm{~b}$ & 52 & 29 & 58 & 25 & 35 & 45 \\
\hline 1987 & b & $\mathrm{b}$ & 55 & 29 & 58 & 23 & 35 & 45 \\
\hline 1988 & b & $b$ & 58 & 35 & 62 & 25 & 38 & 48 \\
\hline 1989 & b & $\mathrm{b}$ & 65 & 42 & 70 & 26 & 43 & 52 \\
\hline 1990 & $\mathrm{~b}$ & $b$ & 65 & 44 & 72 & 31 & 41 & 54 \\
\hline 1991 & b & $\mathrm{b}$ & 64 & 45 & 73 & 27 & 41 & 58 \\
\hline 1992 & $\mathrm{~b}$ & $\mathrm{~b}$ & 60 & 47 & 73 & 28 & 43 & 57 \\
\hline 1993 & 24 & 28 & 65 & 46 & 74 & 28 & 47 & 60 \\
\hline 1994 & b & 33 & 66 & 44 & 79 & 32 & 45 & 62 \\
\hline 1995 & 21 & 36 & 69 & 48 & 79 & 29 & 46 & 61 \\
\hline 1996 & 21 & 35 & 69 & 49 & 81 & 31 & 47 & 62 \\
\hline 1997 & 22 & 38 & 74 & 53 & 85 & 32 & 49 & 65 \\
\hline 1998 & 22 & 39 & 79 & 53 & 88 & 32 & 51 & 70 \\
\hline 1999 & 21 & 38 & 79 & 51 & 85 & 30 & 49 & 67 \\
\hline 2000 & 20 & 38 & 79 & 53 & 86 & 29 & 49 & 66 \\
\hline 2001 & 20 & 37 & 78 & 53 & 87 & 29 & 51 & 64 \\
\hline 2002 & 21 & 38 & 85 & 54 & 87 & 31 & 53 & 69 \\
\hline 2003 & 22 & 32 & 86 & 59 & 89 & 32 & 52 & 71 \\
\hline 2004 & 22 & 35 & 91 & 60 & 94 & 33 & 55 & 75 \\
\hline 2005 & 24 & 37 & 92 & 62 & 99 & 33 & 56 & 79 \\
\hline 2006 & 24 & 38 & 97 & 63 & 102 & 31 & 52 & 83 \\
\hline 2007 & 26 & 41 & 109 & 71 & 113 & 34 & 56 & 93 \\
\hline 2008 & 33 & 50 & 134 & 86 & 135 & 40 & 69 & 113 \\
\hline 2009 & 29 & 49 & 136 & 81 & 136 & 38 & 72 & 112 \\
\hline
\end{tabular}

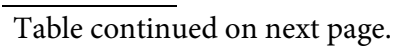


Appendix Table 7. Historical Average Cash Rental Rates of Nebraska Farmland for Different Types of Land by Agricultural Statistics District, 1981-2019 ${ }^{a}$ (continued)

\begin{tabular}{|c|c|c|c|c|c|c|c|c|}
\hline \multirow{2}{*}{$\begin{array}{c}\text { Type of } \\
\text { Land and } \\
\text { Year }\end{array}$} & \multicolumn{7}{|c|}{ Agricultural Statistics District } \\
\cline { 2 - 8 } & Northwest & North & Northeast & Central & East & Southwest & South & Southeast \\
\hline
\end{tabular}

Dryland Cropland

$\begin{array}{rrrrrrrrr}\mathbf{2 0 1 0} & 31 & \text { b } & 144 & 83 & 146 & 41 & 74 & 116 \\ \mathbf{2 0 1 1} & 35 & 52 & 180 & 94 & 178 & 48 & 96 & 142 \\ \mathbf{2 0 1 2} & 39 & 55 & 212 & 110 & 204 & 56 & 116 & 162 \\ \mathbf{2 0 1 3} & 40 & 57 & 234 & 118 & 219 & 59 & 125 & 174 \\ \mathbf{2 0 1 4} & 40 & 70 & 245 & 110 & 215 & 50 & 90 & 175 \\ \mathbf{2 0 1 5} & 35 & 65 & 235 & 105 & 205 & 45 & 85 & 170 \\ \mathbf{2 0 1 6} & 32 & 60 & 225 & 96 & 200 & 42 & 80 & 165 \\ \mathbf{2 0 1 7} & 29 & 55 & 215 & 88 & 195 & 39 & 72 & 155 \\ \mathbf{2 0 1 8} & 28 & 53 & 210 & 89 & 190 & 41 & 76 & 160 \\ \mathbf{2 0 1 9} & 27 & 50 & 205 & 84 & 200 & 38 & 73 & 155\end{array}$

Table continued on next page. 
Appendix Table 7. Historical Average Cash Rental Rates of Nebraska Farmland for Different Types of Land by Agricultural Statistics District, 1981-2019 ${ }^{a}$ (continued)

\begin{tabular}{|c|c|c|c|c|c|c|c|c|}
\hline \multirow{2}{*}{$\begin{array}{c}\text { Type of } \\
\text { Land and } \\
\text { Year }\end{array}$} & \multicolumn{7}{|c|}{ Agricultural Statistics District } \\
\cline { 2 - 9 } & Northwest & North & Northeast & Central & East & Southwest & South & Southeast \\
\hline
\end{tabular}

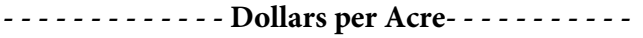

Gravity Irrigated Cropland

\begin{tabular}{|c|c|c|c|c|c|c|c|c|}
\hline 1981 & b & $\mathrm{b}$ & 107 & 114 & 114 & 97 & 117 & 115 \\
\hline 1982 & 100 & 96 & $\mathrm{~b}$ & 119 & 116 & 97 & 115 & 115 \\
\hline 1983 & 93 & 95 & $\mathrm{~b}$ & 110 & 111 & 92 & 110 & 112 \\
\hline 1984 & 110 & 95 & 100 & 115 & 113 & 89 & 115 & 113 \\
\hline 1985 & 91 & 90 & 89 & 105 & 99 & 80 & 103 & 98 \\
\hline 1986 & 78 & 73 & 80 & 90 & 97 & 77 & 93 & 88 \\
\hline 1987 & b & 67 & 83 & 88 & 96 & 76 & 91 & 85 \\
\hline 1988 & b & 70 & 94 & 94 & 103 & 76 & 95 & 93 \\
\hline 1989 & b & 87 & 102 & 111 & 115 & 88 & 106 & 97 \\
\hline 1990 & 74 & 88 & 99 & 113 & 113 & 96 & 106 & 104 \\
\hline 1991 & 84 & 95 & 99 & 119 & 118 & 101 & 112 & 103 \\
\hline 1992 & 83 & 101 & 98 & 109 & 119 & 99 & 118 & 109 \\
\hline 1993 & 77 & 93 & 107 & 118 & 124 & 94 & 124 & 114 \\
\hline 1994 & 83 & 100 & 110 & 121 & 131 & 107 & 124 & 122 \\
\hline 1995 & 80 & 98 & 108 & 120 & 127 & 101 & 123 & 116 \\
\hline 1996 & 78 & 99 & 108 & 124 & 127 & 104 & 126 & 118 \\
\hline 1997 & 80 & 105 & 114 & 129 & 136 & 108 & 132 & 125 \\
\hline 1998 & 91 & 105 & 116 & 129 & 136 & 103 & 133 & 128 \\
\hline 1999 & 85 & 102 & 111 & 123 & 133 & 98 & 130 & 119 \\
\hline 2000 & 82 & 98 & 118 & 123 & 133 & 100 & 128 & 120 \\
\hline 2001 & 84 & 98 & 122 & 128 & 133 & 106 & 127 & 126 \\
\hline 2002 & 84 & 100 & 124 & 128 & 136 & 104 & 128 & 131 \\
\hline 2003 & 86 & 98 & 120 & 129 & 135 & 97 & 125 & 128 \\
\hline 2004 & 88 & 105 & 129 & 134 & 138 & 101 & 128 & 131 \\
\hline 2005 & 94 & 104 & 133 & 134 & 142 & 105 & 130 & 134 \\
\hline 2006 & 97 & 105 & 135 & 135 & 144 & 101 & 130 & 138 \\
\hline 2007 & 103 & 115 & 156 & 150 & 160 & 107 & 139 & 152 \\
\hline 2008 & 126 & 142 & 188 & 173 & 189 & 116 & 168 & 185 \\
\hline 2009 & 110 & 139 & 190 & 169 & 196 & 117 & 171 & 187 \\
\hline
\end{tabular}

Table continued on next page. 
Appendix Table 7. Historical Average Cash Rental Rates of Nebraska Farmland for Different Types of Land by Agricultural Statistics District, 1981-2019 ${ }^{a}$ (continued)

\begin{tabular}{|c|c|c|c|c|c|c|c|c|}
\hline \multirow{2}{*}{$\begin{array}{c}\text { Type of } \\
\text { Land and } \\
\text { Year }\end{array}$} & \multicolumn{7}{|c|}{ Agricultural Statistics District } \\
\cline { 2 - 8 } & Northwest & North & Northeast & Central & East & Southwest & South & Southeast \\
\hline
\end{tabular}

Gravity Irrigated Cropland

$\begin{array}{lrrrrrrrr}\mathbf{2 0 1 0} & 115 & \text { b } & 207 & 174 & 208 & 130 & 183 & 197 \\ \mathbf{2 0 1 1} & \text { b } & \text { b } & 248 & 197 & 259 & \text { b } & 211 & 236 \\ \mathbf{2 0 1 2} & \text { b } & \text { b } & 285 & 230 & 297 & 184 & 247 & 267 \\ \mathbf{2 0 1 3} & \text { b } & \text { b } & 319 & 260 & 320 & 210 & 275 & 299 \\ \mathbf{2 0 1 4} & 145 & 205 & 290 & 250 & 315 & 190 & 225 & 295 \\ \mathbf{2 0 1 5} & 135 & 195 & 285 & 235 & 300 & 185 & 220 & 255 \\ \mathbf{2 0 1 6} & 125 & 175 & 275 & 230 & 285 & 180 & 215 & 250 \\ \mathbf{2 0 1 7} & 120 & 165 & 255 & 220 & 260 & 170 & 205 & 235 \\ \mathbf{2 0 1 8} & 115 & 170 & 250 & 205 & 255 & 165 & 200 & 225 \\ \mathbf{2 0 1 9} & 110 & 165 & 255 & 195 & 245 & 155 & 190 & 220\end{array}$

Table continued on next page. 
Appendix Table 7. Historical Average Cash Rental Rates of Nebraska Farmland for Different Types of Land by Agricultural Statistics District, 1981-2019 ${ }^{a}$ (continued)

\begin{tabular}{|c|c|c|c|c|c|c|c|c|}
\hline \multirow{2}{*}{$\begin{array}{c}\text { Type of } \\
\text { Land and } \\
\text { Year }\end{array}$} & \multicolumn{7}{|c|}{ Agricultural Statistics District } \\
\cline { 2 - 9 } & Northwest & North & Northeast & Central & East & Southwest & South & Southeast \\
\hline
\end{tabular}

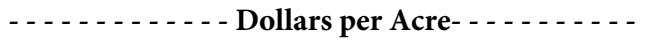

Center Pivot Irrigated Cropland

\begin{tabular}{|c|c|c|c|c|c|c|c|c|}
\hline 1981 & b & 71 & 117 & 102 & 118 & 91 & 126 & 119 \\
\hline 1982 & 98 & 82 & 116 & 108 & 120 & 93 & 127 & 119 \\
\hline 1983 & 90 & 86 & 101 & 100 & 114 & 83 & 117 & 116 \\
\hline 1984 & 98 & 81 & 99 & 101 & 118 & 80 & 120 & 114 \\
\hline 1985 & $\mathrm{~b}$ & 69 & 93 & 90 & 104 & 81 & 111 & 96 \\
\hline 1986 & b & 60 & 86 & 75 & 99 & 69 & 91 & 86 \\
\hline 1987 & b & 62 & 83 & 77 & 97 & 66 & 82 & 86 \\
\hline 1988 & b & 67 & 91 & 82 & 100 & 73 & 89 & 93 \\
\hline 1989 & b & 88 & 99 & 98 & 110 & 81 & 101 & 100 \\
\hline 1990 & 77 & 97 & 106 & 99 & 114 & 91 & 104 & 108 \\
\hline 1991 & 85 & 98 & 108 & 109 & 120 & 94 & 115 & 110 \\
\hline 1992 & 79 & 96 & 105 & 102 & 120 & 92 & 119 & 113 \\
\hline 1993 & 79 & 83 & 107 & 108 & 124 & 93 & 124 & 114 \\
\hline 1994 & 85 & 104 & 115 & 116 & 130 & 98 & 126 & 122 \\
\hline 1995 & 86 & 100 & 118 & 117 & 128 & 101 & 127 & 122 \\
\hline 1996 & 80 & 107 & 117 & 119 & 130 & 105 & 128 & 124 \\
\hline 1997 & 90 & 115 & 124 & 130 & 142 & 110 & 138 & 132 \\
\hline 1998 & 95 & 115 & 125 & 132 & 143 & 111 & 138 & 132 \\
\hline 1999 & 90 & 109 & 122 & 124 & 143 & 110 & 136 & 127 \\
\hline 2000 & 93 & 105 & 125 & 124 & 144 & 111 & 135 & 129 \\
\hline 2001 & 94 & 106 & 130 & 129 & 144 & 113 & 132 & 134 \\
\hline 2002 & 96 & 108 & 132 & 131 & 146 & 115 & 133 & 135 \\
\hline 2003 & 97 & 105 & 137 & 134 & 145 & 115 & 135 & 138 \\
\hline 2004 & 97 & 114 & 144 & 139 & 151 & 117 & 139 & 143 \\
\hline 2005 & 107 & 119 & 142 & 139 & 155 & 121 & 143 & 147 \\
\hline 2006 & 102 & 120 & 147 & 140 & 157 & 120 & 139 & 152 \\
\hline 2007 & 118 & 136 & 173 & 156 & 176 & 128 & 154 & 169 \\
\hline 2008 & 140 & 159 & 208 & 185 & 211 & 139 & 183 & 198 \\
\hline 2009 & 135 & 158 & 207 & 182 & 216 & 160 & 190 & 208 \\
\hline
\end{tabular}

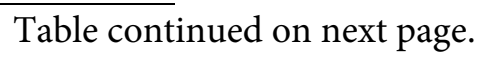


Appendix Table 7. Historical Average Cash Rental Rates of Nebraska Farmland for Different Types of Land by Agricultural Statistics District, 1981-2019 ${ }^{a}$ (continued)

\begin{tabular}{|c|c|c|c|c|c|c|c|c|}
\hline \multirow{2}{*}{$\begin{array}{c}\text { Type of } \\
\text { Land and } \\
\text { Year }\end{array}$} & \multicolumn{7}{|c|}{ Agricultural Statistics District } \\
\cline { 2 - 9 } & Northwest & North & Northeast & Central & East & Southwest & South & Southeast \\
\hline
\end{tabular}

Center Pivot Irrigated Cropland

$\begin{array}{lllllllll}\mathbf{2 0 1 0} & 140 & 168 & 232 & 193 & 234 & 162 & 198 & 214 \\ \mathbf{2 0 1 1} & 171 & 195 & 279 & 221 & 273 & 193 & 233 & 257 \\ \mathbf{2 0 1 2} & 200 & 234 & 330 & 256 & 315 & 236 & 279 & 305 \\ \mathbf{2 0 1 3} & 225 & 265 & 379 & 287 & 355 & 269 & 313 & 345 \\ \mathbf{2 0 1 4} & 200 & 250 & 370 & 260 & 355 & 305 & 270 & 335 \\ \mathbf{2 0 1 5} & 175 & 235 & 365 & 245 & 330 & 250 & 255 & 300 \\ \mathbf{2 0 1 6} & 170 & 220 & 345 & 240 & 320 & 225 & 240 & 290 \\ \mathbf{2 0 1 7} & 155 & 205 & 305 & 230 & 290 & 200 & 225 & 265 \\ \mathbf{2 0 1 8} & 150 & 200 & 290 & 220 & 280 & 190 & 215 & 260 \\ \mathbf{2 0 1 9} & 145 & 185 & 280 & 215 & 285 & 175 & 205 & 250\end{array}$

Table continued on next page. 
Appendix Table 7. Historical Average Cash Rental Rates of Nebraska Farmland for Different Types of Land by Agricultural Statistics District, 1981-2019 ${ }^{a}$ (continued)

\begin{tabular}{|c|c|c|c|c|c|c|c|c|}
\hline $\begin{array}{c}\text { Type of } \\
\text { Land and } \\
\text { Year }\end{array}$ & \multicolumn{8}{|c|}{ Agricultural Statistics District } \\
\cline { 2 - 8 } & Northwest & North & Northeast & Central & East & Southwest & South & Southeast \\
\hline
\end{tabular}

Dryland Alfalfa

\begin{tabular}{|c|c|c|c|c|c|c|c|c|}
\hline 1981 & b & $\mathrm{b}$ & 53 & 47 & 56 & 31 & 45 & 45 \\
\hline 1982 & b & $\mathrm{b}$ & 57 & 47 & 64 & 31 & 43 & 47 \\
\hline 1983 & b & $\mathrm{b}$ & 56 & 43 & 64 & 32 & 43 & 50 \\
\hline 1984 & b & $\mathrm{b}$ & 50 & 46 & 63 & 36 & 44 & 45 \\
\hline 1985 & b & $\mathrm{b}$ & 50 & 44 & 59 & 28 & 42 & 40 \\
\hline 1986 & b & b & 47 & 32 & 52 & 25 & 44 & 40 \\
\hline 1987 & b & $\mathrm{b}$ & 41 & 32 & 53 & b & 41 & 37 \\
\hline 1988 & b & $\mathrm{b}$ & 52 & 36 & 58 & b & 42 & 39 \\
\hline 1989 & b & $\mathrm{b}$ & 59 & 41 & 64 & b & 56 & 48 \\
\hline 1990 & b & $\mathrm{b}$ & 62 & 49 & 67 & 30 & b & 48 \\
\hline 1991 & b & 38 & 62 & 57 & 71 & 28 & b & 49 \\
\hline 1992 & b & 36 & 56 & 46 & 58 & b & 50 & 48 \\
\hline 1993 & b & 27 & 65 & 47 & 66 & 31 & 50 & 54 \\
\hline 1994 & b & $\mathrm{b}$ & 65 & 46 & 70 & 37 & 51 & 52 \\
\hline 1995 & b & $\mathrm{b}$ & 68 & 50 & 73 & b & 54 & 57 \\
\hline 1996 & b & $\mathrm{b}$ & 68 & 52 & 78 & b & 51 & 54 \\
\hline 1997 & b & $\mathrm{b}$ & 72 & 56 & 82 & b & 54 & 60 \\
\hline 1998 & b & $\mathrm{b}$ & 79 & 58 & 86 & b & 59 & 64 \\
\hline 1999 & b & $\mathrm{b}$ & 80 & 54 & 82 & b & b & 64 \\
\hline 2000 & b & $\mathrm{b}$ & 80 & 56 & 82 & b & b & $\mathrm{b}$ \\
\hline 2001 & b & $\mathrm{b}$ & 79 & 53 & 79 & b & b & b \\
\hline 2002 & b & $\mathrm{b}$ & 86 & 55 & 82 & b & 56 & b \\
\hline 2003 & b & $\mathrm{b}$ & 84 & 62 & 77 & b & 53 & 68 \\
\hline 2004 & b & $\mathrm{b}$ & 92 & 63 & 85 & b & 53 & 74 \\
\hline 2005 & b & $\mathrm{b}$ & 90 & 59 & 82 & b & 58 & b \\
\hline 2006 & b & b & 89 & 54 & 87 & b & 59 & 80 \\
\hline 2007 & b & $\mathrm{b}$ & 105 & 63 & 96 & b & b & b \\
\hline 2008 & b & $\mathrm{b}$ & 126 & 73 & 120 & b & b & b \\
\hline 2009 & b & $\mathrm{b}$ & 121 & 68 & 120 & b & b & b \\
\hline
\end{tabular}

Table continued on next page. 
Appendix Table 7. Historical Average Cash Rental Rates of Nebraska Farmland for Different Types of Land by Agricultural Statistics District, 1981-2019 ${ }^{a}$ (continued)

\begin{tabular}{|c|c|c|c|c|c|c|c|c|}
\hline \multirow{2}{*}{$\begin{array}{c}\text { Type of } \\
\text { Land and } \\
\text { Year }\end{array}$} & \multicolumn{6}{|c|}{ Agricultural Statistics District } \\
\cline { 2 - 8 } & Northwest & North & Northeast & Central & East & Southwest & South & Southeast \\
\hline
\end{tabular}

Dryland Alfalfa

$\begin{array}{lrrrrrrrr}\mathbf{2 0 1 0} & \text { b } & \text { b } & 124 & 71 & 118 & \text { b } & \text { b } & \text { b } \\ \mathbf{2 0 1 1} & \text { b } & \text { b } & 152 & 81 & 140 & \text { b } & \text { b } & \text { b } \\ \mathbf{2 0 1 2} & \text { b } & \text { b } & 198 & 105 & 182 & \text { b } & \text { b } & \text { b } \\ \mathbf{2 0 1 3} & \text { b } & \text { b } & 235 & 122 & 200 & \text { b } & \text { b } & \text { b } \\ \mathbf{2 0 1 4} & 40 & 100 & 244 & 91 & 168 & 46 & 88 & 147 \\ \mathbf{2 0 1 5} & 30 & 75 & 220 & 85 & 165 & 35 & 80 & 140 \\ \mathbf{2 0 1 6} & 28 & 58 & 205 & 80 & 155 & 32 & 76 & 130 \\ \mathbf{2 0 1 7} & 26 & 47 & 190 & 75 & 160 & 30 & 71 & 120 \\ \mathbf{2 0 1 8} & 27 & 45 & 185 & 73 & 150 & 29 & 68 & 125 \\ \mathbf{2 0 1 9} & 24 & 44 & 180 & 71 & 155 & 28 & 65 & 120\end{array}$

Table continued on next page. 
Appendix Table 7. Historical Average Cash Rental Rates of Nebraska Farmland for Different Types of Land by Agricultural Statistics District, 1981-2019 ${ }^{a}$ (continued)

\begin{tabular}{|c|c|c|c|c|c|c|c|c|}
\hline $\begin{array}{c}\text { Type of } \\
\text { Land and } \\
\text { Year }\end{array}$ & \multicolumn{7}{|c|}{ Agricultural Statistics District } \\
\cline { 2 - 8 } & Northwest & North & Northeast & Central & East & Southwest & South & Southeast \\
\hline
\end{tabular}

Irrigated Alfalfa

\begin{tabular}{|c|c|c|c|c|c|c|c|c|}
\hline 1981 & $\mathrm{~b}$ & $\mathrm{~b}$ & 88 & 92 & 96 & b & 90 & b \\
\hline 1982 & $\mathrm{~b}$ & $\mathrm{~b}$ & 75 & 87 & 100 & 56 & 90 & b \\
\hline 1983 & $\mathrm{~b}$ & $\mathrm{~b}$ & 78 & 89 & 105 & 70 & 84 & b \\
\hline 1984 & $\mathrm{~b}$ & $\mathrm{~b}$ & 80 & 83 & 96 & 68 & 84 & b \\
\hline 1985 & $\mathrm{~b}$ & $\mathrm{~b}$ & 74 & 80 & 87 & $\mathrm{~b}$ & 69 & b \\
\hline 1986 & $\mathrm{~b}$ & $\mathrm{~b}$ & 68 & 58 & 69 & $\mathrm{~b}$ & 68 & b \\
\hline 1987 & $\mathrm{~b}$ & $\mathrm{~b}$ & 61 & 62 & 70 & $b$ & 68 & b \\
\hline 1988 & $\mathrm{~b}$ & $\mathrm{~b}$ & 72 & 66 & 78 & $\mathrm{~b}$ & 68 & b \\
\hline 1989 & $\mathrm{~b}$ & $\mathrm{~b}$ & 89 & 88 & 92 & b & 100 & b \\
\hline 1990 & b & $\mathrm{b}$ & 96 & 95 & 93 & 90 & 111 & b \\
\hline 1991 & $\mathrm{~b}$ & $\mathrm{~b}$ & 98 & 98 & 102 & 78 & 98 & b \\
\hline 1992 & $\mathrm{~b}$ & $\mathrm{~b}$ & 88 & 81 & 82 & $\mathrm{~b}$ & 94 & b \\
\hline 1993 & $\mathrm{~b}$ & $\mathrm{~b}$ & 96 & 96 & 92 & $b$ & 100 & b \\
\hline 1994 & $\mathrm{~b}$ & $\mathrm{~b}$ & 99 & 93 & 101 & $\mathrm{~b}$ & 95 & b \\
\hline 1995 & $\mathrm{~b}$ & $\mathrm{~b}$ & 99 & 102 & 101 & $b$ & 103 & b \\
\hline 1996 & $\mathrm{~b}$ & $\mathrm{~b}$ & 108 & 106 & 108 & $b$ & 109 & b \\
\hline 1997 & $\mathrm{~b}$ & $\mathrm{~b}$ & 113 & 106 & 119 & $\mathrm{~b}$ & b & b \\
\hline 1998 & $\mathrm{~b}$ & $\mathrm{~b}$ & 118 & 112 & 124 & $\mathrm{~b}$ & b & b \\
\hline 1999 & $\mathrm{~b}$ & $\mathrm{~b}$ & 112 & 108 & 115 & $\mathrm{~b}$ & b & b \\
\hline 2000 & $\mathrm{~b}$ & $\mathrm{~b}$ & 105 & 107 & 114 & $b$ & b & b \\
\hline 2001 & $\mathrm{~b}$ & $\mathrm{~b}$ & 118 & 107 & 118 & $\mathrm{~b}$ & b & b \\
\hline 2002 & $\mathrm{~b}$ & $\mathrm{~b}$ & 124 & 111 & 121 & $\mathrm{~b}$ & 116 & $\mathrm{~b}$ \\
\hline 2003 & $\mathrm{~b}$ & $\mathrm{~b}$ & 125 & 121 & 124 & $\mathrm{~b}$ & 117 & $\mathrm{~b}$ \\
\hline 2004 & $\mathrm{~b}$ & $\mathrm{~b}$ & 132 & 126 & 128 & $\mathrm{~b}$ & 123 & 126 \\
\hline 2005 & $\mathrm{~b}$ & $\mathrm{~b}$ & 130 & 121 & 119 & $\mathrm{~b}$ & 124 & b \\
\hline 2006 & $\mathrm{~b}$ & $\mathrm{~b}$ & 132 & 123 & 120 & b & 125 & b \\
\hline 2007 & $\mathrm{~b}$ & $\mathrm{~b}$ & b & 138 & 162 & b & b & b \\
\hline 2008 & $\mathrm{~b}$ & $\mathrm{~b}$ & 142 & 165 & 172 & b & b & b \\
\hline 2009 & $\mathrm{~b}$ & $\mathrm{~b}$ & 158 & 159 & 170 & b & b & b \\
\hline
\end{tabular}

Table continued on next page. 
Appendix Table 7. Historical Average Cash Rental Rates of Nebraska Farmland for Different Types of Land by Agricultural Statistics District, 1981-2019 ${ }^{a}$ (continued)

\begin{tabular}{|c|c|c|c|c|c|c|c|c|}
\hline \multirow{2}{*}{$\begin{array}{c}\text { Type of } \\
\text { Land and } \\
\text { Year }\end{array}$} & \multicolumn{8}{|c|}{ Agricultural Statistics District } \\
\cline { 2 - 8 } & Northwest & North & Northeast & Central & East & Southwest & South & Southeast \\
\hline
\end{tabular}

Irrigated Alfalfa

$\begin{array}{rrrrrrrrr}\mathbf{2 0 1 0} & \text { b } & \text { b } & \text { b } & 153 & \text { b } & \text { b } & \text { b } & \text { b } \\ \mathbf{2 0 1 1} & \text { b } & \text { b } & \text { b } & 172 & \text { b } & \text { b } & \text { b } & \text { b } \\ \mathbf{2 0 1 2} & \text { b } & \text { b } & \text { b } & 197 & 265 & \text { b } & \text { b } & \text { b } \\ \mathbf{2 0 1 3} & \text { b } & \text { b } & \text { b } & 254 & 293 & \text { b } & \text { b } & \text { b } \\ \mathbf{2 0 1 4} & 198 & 250 & 350 & 216 & 275 & 211 & 240 & 335 \\ \mathbf{2 0 1 5} & 150 & 165 & 290 & 175 & 265 & 175 & 235 & 295 \\ \mathbf{2 0 1 6} & 145 & 155 & 260 & 170 & 255 & 165 & 215 & 280 \\ \mathbf{2 0 1 7} & 120 & 150 & 250 & 165 & 245 & 140 & 215 & 260 \\ \mathbf{2 0 1 8} & 115 & 140 & 245 & 195 & 240 & 135 & 195 & 230 \\ \mathbf{2 0 1 9} & 110 & 130 & 240 & 190 & 250 & 130 & 180 & 225\end{array}$

Table continued on next page. 
Appendix Table 7. Historical Average Cash Rental Rates of Nebraska Farmland for Different Types of Land by Agricultural Statistics District, 1981-2019 ${ }^{a}$ (continued)

\begin{tabular}{|c|c|c|c|c|c|c|c|c|}
\hline $\begin{array}{c}\text { Type of } \\
\text { Land and } \\
\text { Year }\end{array}$ & \multicolumn{7}{|c|}{ Agricultural Statistics District } \\
\cline { 2 - 8 } & Northwest & North & Northeast & Central & East & Southwest & South & Southeast \\
\hline
\end{tabular}

Other Hayland

\begin{tabular}{|c|c|c|c|c|c|c|c|c|}
\hline 1981 & b & 21 & b & 37 & 39 & 34 & $\mathrm{~b}$ & 34 \\
\hline 1982 & b & 18 & b & 30 & $b$ & $\mathrm{~b}$ & $\mathrm{~b}$ & 34 \\
\hline 1983 & b & b & b & 41 & $b$ & $\mathrm{~b}$ & b & 31 \\
\hline 1984 & b & b & b & 32 & 44 & 29 & $\mathrm{~b}$ & 36 \\
\hline 1985 & b & b & b & 38 & 38 & $\mathrm{~b}$ & b & 28 \\
\hline 1986 & b & b & b & 26 & 29 & b & b & 26 \\
\hline 1987 & b & b & b & 28 & 32 & b & b & 24 \\
\hline 1988 & b & b & b & 26 & 31 & $\mathrm{~b}$ & $\mathrm{~b}$ & 31 \\
\hline 1989 & b & b & b & 30 & 44 & b & b & 34 \\
\hline 1990 & b & b & b & 39 & 44 & 34 & $\mathrm{~b}$ & 38 \\
\hline 1991 & b & 18 & 37 & 37 & 43 & 35 & b & 33 \\
\hline 1992 & b & 21 & 31 & 30 & 34 & $\mathrm{~b}$ & 27 & 30 \\
\hline 1993 & b & 22 & 38 & 34 & 38 & b & 35 & 29 \\
\hline 1994 & b & b & 38 & 37 & 39 & $\mathrm{~b}$ & 33 & 29 \\
\hline 1995 & b & b & 41 & 40 & 44 & b & 31 & 34 \\
\hline 1996 & b & b & 42 & 40 & 40 & b & 31 & 36 \\
\hline 1997 & b & b & 42 & 43 & 44 & b & 32 & 38 \\
\hline 1998 & b & b & 48 & 43 & 50 & b & 35 & 40 \\
\hline 1999 & b & b & 48 & 38 & 48 & b & b & b \\
\hline 2000 & b & b & 48 & 35 & 43 & b & $\mathrm{b}$ & b \\
\hline 2001 & b & b & 50 & 37 & 47 & b & b & b \\
\hline 2002 & b & b & 50 & 38 & 51 & b & 36 & b \\
\hline 2003 & b & b & 46 & 36 & 53 & b & 33 & b \\
\hline 2004 & b & b & b & 42 & 57 & $\mathrm{~b}$ & 36 & 42 \\
\hline 2005 & b & b & 52 & 42 & 56 & b & 36 & b \\
\hline 2006 & b & b & b & 39 & 55 & b & 39 & b \\
\hline 2007 & b & b & b & 51 & $\mathrm{~b}$ & b & b & b \\
\hline 2008 & $\mathrm{~b}$ & b & b & 59 & $\mathrm{~b}$ & b & b & b \\
\hline 2009 & 27 & 29 & 67 & 57 & 71 & b & b & b \\
\hline
\end{tabular}

Table continued on next page. 
Appendix Table 7. Historical Average Cash Rental Rates of Nebraska Farmland for Different Types of Land by Agricultural Statistics District, 1981-2019 ${ }^{a}$ (continued)

\begin{tabular}{|c|c|c|c|c|c|c|c|c|}
\hline \multirow{2}{*}{$\begin{array}{c}\text { Type of } \\
\text { Land and } \\
\text { Year }\end{array}$} & \multicolumn{7}{|c|}{ Agricultural Statistics District } \\
\cline { 2 - 8 } & Northwest & North & Northeast & Central & East & Southwest & South & Southeast \\
\hline
\end{tabular}

Other Hayland

$\begin{array}{rrrrrrrrr}\mathbf{2 0 1 0} & 27 & 29 & 52 & 57 & 61 & \text { b } & \text { b } & \text { b } \\ \mathbf{2 0 1 1} & \text { b } & \text { b } & \text { b } & \text { b } & \text { b } & \text { b } & \text { b } & \text { b } \\ \mathbf{2 0 1 2} & \text { b } & \text { b } & \text { b } & \text { b } & \text { b } & \text { b } & \text { b } & \text { b } \\ \mathbf{2 0 1 3} & \text { b } & \text { b } & \text { b } & 92 & 75 & \text { b } & \text { b } & \text { b } \\ \mathbf{2 0 1 4} & 33 & 55 & 138 & 40 & 78 & 39 & 58 & 89 \\ \mathbf{2 0 1 5} & 30 & 55 & 105 & 65 & 95 & 45 & 55 & 65 \\ \mathbf{2 0 1 6} & 27 & 53 & 98 & 62 & 86 & 41 & 50 & 62 \\ \mathbf{2 0 1 7} & 25 & 48 & 95 & 55 & 83 & 42 & 45 & 59 \\ \mathbf{2 0 1 8} & 22 & 46 & 100 & 54 & 85 & 39 & 44 & 57 \\ \mathbf{2 0 1 9} & 21 & 45 & 98 & 55 & 82 & 37 & 43 & 60\end{array}$

Table continued on next page. 
Appendix Table 7. Historical Average Cash Rental Rates of Nebraska Farmland for Different Types of Land by Agricultural Statistics District, 1981-2019 ${ }^{a}$ (continued)

\begin{tabular}{|c|c|c|c|c|c|c|c|c|}
\hline \multirow{2}{*}{$\begin{array}{c}\text { Type of } \\
\text { Land and } \\
\text { Year }\end{array}$} & \multicolumn{6}{|c|}{ Agricultural Statistics District } \\
\cline { 2 - 8 } & Northwest & North & Northeast & Central & East & Southwest & South & Southeast \\
\hline
\end{tabular}

Pastureland (Per Acre)

\begin{tabular}{|c|c|c|c|c|c|c|c|c|}
\hline 1981 & 6 & 8 & 33 & 16 & 28 & 10 & 14 & 26 \\
\hline 1982 & 5 & 9 & 31 & 15 & 22 & 9 & 16 & 24 \\
\hline 1983 & 6 & 9 & 26 & 16 & 21 & 9 & 14 & 24 \\
\hline 1984 & 6 & 8 & 25 & 16 & 23 & 9 & 16 & 23 \\
\hline 1985 & 5 & 6 & 20 & 13 & 23 & 7 & 14 & 20 \\
\hline 1986 & 5 & b & 16 & 10 & 22 & 6 & 10 & 16 \\
\hline 1987 & 4 & 4 & 18 & 10 & 20 & 5 & 11 & 15 \\
\hline 1988 & 4 & 5 & 20 & 12 & 21 & 6 & 12 & 18 \\
\hline 1989 & 5 & 7 & 23 & 15 & 23 & 7 & 15 & 19 \\
\hline 1990 & 5 & 9 & 25 & 17 & 25 & 9 & 15 & 20 \\
\hline 1991 & 6 & 10 & 26 & 20 & 27 & 10 & 17 & 22 \\
\hline 1992 & 7 & 12 & 25 & 18 & 25 & 12 & 18 & 21 \\
\hline 1993 & 6 & 10 & 24 & 21 & 27 & 10 & 19 & 21 \\
\hline 1994 & 9 & 11 & 30 & 21 & 28 & 11 & 20 & 23 \\
\hline 1995 & 7 & 11 & 31 & 21 & 27 & 12 & 19 & 24 \\
\hline 1996 & 7 & 11 & 30 & 20 & 28 & 12 & 19 & 24 \\
\hline 1997 & 8 & 12 & 30 & 21 & 29 & 12 & 20 & 25 \\
\hline 1998 & 8 & 12 & 31 & 22 & 30 & 12 & 21 & 25 \\
\hline 1999 & 7 & 12 & 31 & 21 & 29 & 11 & 20 & 23 \\
\hline 2000 & 7 & 13 & 32 & 22 & 29 & 11 & 20 & 21 \\
\hline 2001 & 7 & 12 & 32 & 23 & 30 & 11 & 20 & 22 \\
\hline 2002 & 8 & 13 & 33 & 24 & 32 & 12 & 21 & 25 \\
\hline 2003 & 7 & 11 & 33 & 23 & 28 & 11 & 22 & 24 \\
\hline 2004 & 8 & 13 & 36 & 24 & 32 & 13 & 22 & 27 \\
\hline 2005 & 8 & 13 & 37 & 25 & 32 & 12 & 23 & 27 \\
\hline 2006 & 9 & 14 & 36 & 26 & 33 & 13 & 22 & 29 \\
\hline 2007 & 9 & 15 & 38 & 26 & 36 & 12 & 21 & 30 \\
\hline 2008 & 10 & 16 & 39 & 30 & 36 & 13 & 27 & 35 \\
\hline 2009 & 11 & 16 & 39 & 28 & 36 & 13 & 30 & 34 \\
\hline
\end{tabular}

Table continued on next page. 
Appendix Table 7. Historical Average Cash Rental Rates of Nebraska Farmland for Different Types of Land by Agricultural Statistics District, 1981-2019 ${ }^{a}$ (continued)

\begin{tabular}{|c|c|c|c|c|c|c|c|c|}
\hline \multirow{2}{*}{$\begin{array}{c}\text { Type of } \\
\text { Land and } \\
\text { Year }\end{array}$} & \multicolumn{6}{|c|}{ Agricultural Statistics District } \\
\cline { 2 - 8 } & Northwest & North & Northeast & Central & East & Southwest & South & Southeast \\
\hline
\end{tabular}

Pastureland (Per Acre)

$\begin{array}{lllllllll}\mathbf{2 0 1 0} & 11 & 14 & 40 & 27 & 35 & 13 & 29 & 32 \\ \mathbf{2 0 1 1} & 11 & 14 & 47 & 30 & 37 & 14 & 32 & 34 \\ \mathbf{2 0 1 2} & 13 & 16 & 51 & 33 & 42 & 16 & 36 & 39 \\ \mathbf{2 0 1 3} & 13 & 16 & 53 & 35 & 49 & 17 & 37 & 42 \\ \mathbf{2 0 1 4} & 10 & 25 & 70 & 30 & 55 & 20 & 35 & 50 \\ \mathbf{2 0 1 5} & 14 & 30 & 90 & 40 & 65 & 25 & 40 & 55 \\ \mathbf{2 0 1 6} & 12 & 26 & 75 & 36 & 61 & 24 & 37 & 54 \\ \mathbf{2 0 1 7} & 11 & 25 & 62 & 34 & 53 & 22 & 35 & 49 \\ \mathbf{2 0 1 8} & 10 & 26 & 61 & 33 & 49 & 21 & 36 & 47 \\ \mathbf{2 0 1 9} & 11 & 24 & 59 & 31 & 47 & 19 & 34 & 46\end{array}$

Table continued on next page. 
Appendix Table 7. Historical Average Cash Rental Rates of Nebraska Farmland for Different Types of Land by Agricultural Statistics District, 1981-2019ª (continued)

\begin{tabular}{|c|c|c|c|c|c|c|c|c|}
\hline \multirow{2}{*}{$\begin{array}{c}\text { Type of } \\
\text { Land and } \\
\text { Year }\end{array}$} & \multicolumn{7}{|c|}{ Agricultural Statistics District } \\
\cline { 2 - 8 } & Northwest & North & Northeast & Central & East & Southwest & South & Southeast \\
\hline
\end{tabular}

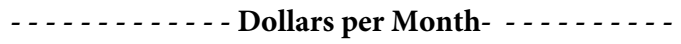

\section{Cow-Calf Pair (Per-Month)}

\begin{tabular}{|c|c|c|c|c|c|c|c|c|}
\hline 1981 & 13.00 & 13.30 & 12.85 & 15.80 & 12.65 & 14.40 & 13.75 & 12.90 \\
\hline 1982 & 13.00 & 12.50 & 15.25 & 15.95 & 13.85 & 16.00 & 15.00 & 14.95 \\
\hline 1983 & 13.40 & 16.60 & 16.50 & 16.65 & 14.50 & 15.45 & 15.21 & 15.81 \\
\hline 1984 & 13.20 & 15.90 & 15.30 & 16.55 & 14.10 & 15.25 & 14.75 & 15.60 \\
\hline 1985 & 12.20 & 12.70 & 12.90 & 13.00 & 12.80 & 13.60 & 12.80 & 13.60 \\
\hline 1986 & 10.70 & 10.50 & 11.00 & 10.60 & 10.10 & 10.40 & 10.70 & 11.30 \\
\hline 1987 & 9.55 & 10.35 & 10.10 & 10.55 & 10.20 & 10.25 & 10.50 & 10.50 \\
\hline 1988 & 9.50 & 11.00 & 10.90 & 11.30 & 13.00 & 12.70 & 12.65 & 13.50 \\
\hline 1989 & 11.35 & 14.50 & 14.00 & 14.50 & 13.25 & 12.80 & 14.20 & 13.70 \\
\hline 1990 & 12.90 & 16.75 & 15.55 & 17.80 & 15.70 & 17.40 & 15.00 & 15.35 \\
\hline 1991 & 14.85 & 20.00 & 18.00 & 20.30 & 19.50 & 18.25 & 17.50 & 18.00 \\
\hline 1992 & 14.60 & 21.00 & 18.80 & 19.95 & 17.40 & 17.65 & 19.00 & 18.00 \\
\hline 1993 & 16.40 & 21.30 & 18.50 & 22.35 & 19.85 & 20.75 & 20.40 & 19.85 \\
\hline 1994 & 17.20 & 23.25 & 19.70 & 23.00 & 21.55 & 23.00 & 23.00 & 21.60 \\
\hline 1995 & 16.75 & 23.40 & 19.90 & 23.00 & 20.50 & 22.30 & 22.20 & 20.30 \\
\hline 1996 & 16.40 & 23.00 & 18.35 & 21.80 & 21.00 & 20.35 & 21.15 & 20.05 \\
\hline 1997 & 17.00 & 23.50 & 20.50 & 22.25 & 22.30 & 21.20 & 21.20 & 20.75 \\
\hline 1998 & 18.10 & 23.70 & 21.00 & 23.40 & 23.60 & 23.40 & 22.20 & 21.70 \\
\hline 1999 & 16.70 & 23.00 & 21.60 & 23.25 & 21.90 & 23.25 & 22.00 & 20.40 \\
\hline 2000 & 18.25 & 23.15 & 23.80 & 23.80 & 22.50 & 24.50 & 22.00 & 21.35 \\
\hline 2001 & 19.65 & 25.10 & 23.40 & 24.45 & 24.00 & 25.00 & 22.20 & 22.75 \\
\hline 2002 & 20.35 & 26.35 & 23.80 & 25.10 & 24.30 & 25.00 & 23.30 & 24.40 \\
\hline 2003 & 19.15 & 26.15 & 25.10 & 24.90 & 24.45 & 24.60 & 23.00 & 23.15 \\
\hline 2004 & 21.00 & 27.65 & 26.80 & 26.35 & 26.00 & 26.25 & 24.00 & 25.15 \\
\hline 2005 & 23.15 & 28.30 & 28.10 & 28.55 & 27.90 & 26.70 & 24.60 & 25.15 \\
\hline 2006 & 23.00 & 29.40 & 29.70 & 28.70 & 28.00 & 26.70 & 26.00 & 25.80 \\
\hline 2007 & 25.00 & 29.55 & 29.15 & 27.75 & 26.00 & 25.70 & 25.00 & 25.15 \\
\hline 2008 & 26.25 & 33.65 & 31.90 & 33.10 & 31.60 & 31.40 & 27.75 & 29.85 \\
\hline 2009 & 26.90 & 33.60 & 33.00 & 33.35 & 30.70 & 30.50 & 30.00 & 29.50 \\
\hline
\end{tabular}

Table continued on next page. 
Appendix Table 7. Historical Average Cash Rental Rates of Nebraska Farmland for Different Types of Land by Agricultural Statistics District, 1981-2019 ${ }^{a}$ (continued)

\begin{tabular}{|c|c|c|c|c|c|c|c|c|}
\hline \multirow{2}{*}{$\begin{array}{c}\text { Type of } \\
\text { Land and } \\
\text { Year }\end{array}$} & \multicolumn{7}{|c|}{ Agricultural Statistics District } \\
\cline { 2 - 8 } & Northwest & North & Northeast & Central & East & Southwest & South & Southeast \\
\hline
\end{tabular}

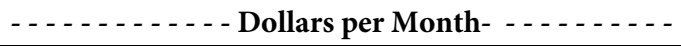

\section{Cow-Calf Pair (Per-Month)}

\begin{tabular}{|c|c|c|c|c|c|c|c|c|}
\hline 2010 & 26.40 & 33.00 & 33.60 & 32.90 & 31.25 & 29.50 & 28.50 & 30.80 \\
\hline 2011 & 28.00 & 34.00 & 35.70 & 33.30 & 35.80 & 33.85 & 32.00 & 32.90 \\
\hline 2012 & 30.80 & 38.60 & 40.00 & 38.10 & 38.35 & 37.00 & 38.30 & 38.20 \\
\hline 2013 & 30.50 & 39.00 & 42.35 & 40.75 & 41.30 & 39.20 & 39.00 & 39.40 \\
\hline 2014 & 32.30 & 48.55 & 55.00 & 59.95 & 49.00 & 45.45 & 32.10 & 43.00 \\
\hline 2015 & 39.40 & 65.55 & 62.05 & 67.10 & 64.55 & 60.70 & 57.50 & 58.90 \\
\hline 2016 & 36.15 & 63.80 & 59.70 & 58.10 & 56.40 & 57.20 & 49.10 & 52.00 \\
\hline 2017 & 35.05 & 61.05 & 53.20 & 53.30 & 51.10 & 51.65 & 47.30 & 48.50 \\
\hline 2018 & 35.65 & 58.95 & 52.55 & 52.30 & 48.25 & 49.50 & 46.45 & 47.05 \\
\hline 2019 & 36.15 & 57.50 & 54.90 & 50.70 & 49.15 & 46.35 & 44.10 & 45.15 \\
\hline
\end{tabular}

Source: a Panel members reported annual estimates of cash rental rates in the annual UNL Nebraska Farm Real Estate Market Surveys, 1981-2019.

${ }^{\mathrm{b}}$ Insufficient number of reports.

${ }^{\mathrm{c}} \mathrm{A}$ cow-calf pair is typically considered to be 1.25 to 1.30 animal units. However, this may vary depending on weight of cow and age of calf. 